\title{
Lower Paleozoic oil and gas shale in the Baltic-Podlasie-Lublin Basin (central and eastern Europe) - a review
}

\author{
Paweł POPRAWA ${ }^{1, *}$ \\ 1 AGH University of Science and Technology, al. A. Mickiewicza 30, 30-059 Kraków, Poland
}

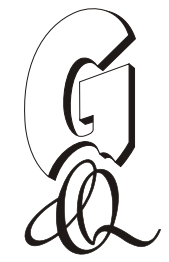

Poprawa, P., 2020. Lower Paleozoic oil and gas shale in the Baltic-Podlasie-Lublin Basin (central and eastern Europe) a review. Geological Quarterly, 64 (3): 515-566, doi: 10.7306/gq.1542

\begin{abstract}
In the Baltic-Podlasie-Lublin Basin, four potential lower Paleozoic shale reservoirs are identified: the Piaśnica, Sasino and Jantar formations, as well as the Mingajny shale. These units were diachronously deposited during the starved stages of Caledonian foredeep basin development, in the course of rising or high eustatic sea level. Across most of the basin, the shale formations analysed are saturated with light oil and condensate, and they are buried to depths of $2300-3500 \mathrm{~m}$. The shale reservoirs reach the wet gas window at burial depths of $2800-4000 \mathrm{~m}$, while dry gas accumulations occur at depths exceeding 3500-5000 m, except in the Biłgoraj-Narol Zone. The shale analysed might be generally classified as a moderate to low quality, and locally high quality, unconventional reservoir. Within the shale net pay zones, the average TOC content is $2-5$ wt.\% TOC. The exceptions are the Piaśnica Formation, for which this is $5-12$ wt.\%, and the Mingajny shale, which is TOC-lean (1.4-1.7 wt.\%). The thickness of the shale net pay intervals in the most favourable locations, mainly on the Łeba Elevation, generally reaches $20 \mathrm{~m}$, and locally exceeds $35 \mathrm{~m}$. The shale reservoirs are saturated with hydrocarbons of good quality. Their permeability is low to moderate, often in the range of 150-200 mD, while total porosity average per borehole is commonly exceeds $6 \%$, reaching up to $10 \%$ at maximum, which might be considered as moderate to good. The clay minerals content is moderate to high (30-50\%), and geomechanical characteristics of the shale formations are in termediate between brittle and ductile. No overpressure occurs in the basin, except for a dry gas zone in the SW Baltic Basin. In the Biłgoraj-Narol Zone, and to a lesser degree also in the Lublin region, pronounced tectonic deformation significantly limits shale gas/oil potential. Among 66 exploration boreholes drilled in the basin so far, only 5 were latera boreholes with representative production test results. Hydrocarbon flow from the best boreholes was low to moderate, equal to 11.2 to 15.6 thousand $\mathrm{m}^{3} /$ day for gas, and $157 \mathrm{bbl} /$ day $(\sim 21.4$ ton/day) for oil. There is, however, high potential to improve production flow rates, connected with the fracturing of two net pay intervals at one time, as well as with significant technological progress in the exploitation of shale basins during the last 5 years. Commercially viable production might be achieved for a single borehole with estimated ultimate recovery exceeding 30-50 thousand tons of oil, or 60-90 million $\mathrm{m}^{3}$ of gas.
\end{abstract}

Key words: Baltic-Podlasie-Lublin Basin, lower Paleozoic, shale oil, shale gas, reservoir characteristics.

\section{INTRODUCTION}

Since the 1990s a new hydrocarbon exploration concept, regarding fine-grained sediments as gas reservoirs, began to change the North American petroleum industry considerably. After roughly a decade of small-scale tests and innovative developments, shale gas production in the USA accelerated significantly in 2005-2007 to a scale which on the one hand side caused gas prices in North America to collapse, but on the other hand turned USA into a net gas exporter (PPI Energy and Chemicals Team, 2013; Wang and Krupnick, 2015; IEA, 2015, 2019; CEA, 2019). Due to the consequences of this process for the petroleum industry, as well as its economic and geopolitical significance, it is commonly referred to as the "shale gas revolu-

\section{*E-mail: ppop.ecr@gmail.com}

Received: February 3, 2020; accepted: April 8, 2020; first published online: July 16,2020 tion" (e.g., Middleton et al., 2017). The second phase of the "shale revolution" was initiated roughly in 2009 , when economically successful large-scale development of oil and condensate production from shale and hybrid reservoirs began (EIA, 2011; Kuuskraa et al., 2013; IEA, 2015). As a consequence of this, the USA is currently the biggest oil and gas producer globally (CEA, 2019).

Successful development of shale gas and shale oil projects in the USA, and on a smaller scale in Canada, brought with it intense global attention, and precipitated attempts to implement this concept in petroleum basins across the world (EIA, 2013; Boros, 2014; IEA, 2015; Zijp et al., 2017; Le, 2018). In the course of this, Poland became the first country outside North America to host shale gas/oil exploration, which during the last decade has delivered for science and industry a significant amount of new data. Since shale gas/oil exploration in Poland currently ceased, it seems now appropriate to summarize its major outcomes.

This paper therefore overviews the exploration for shale gas and shale oil in Poland, and to a lesser degree also in sur- 


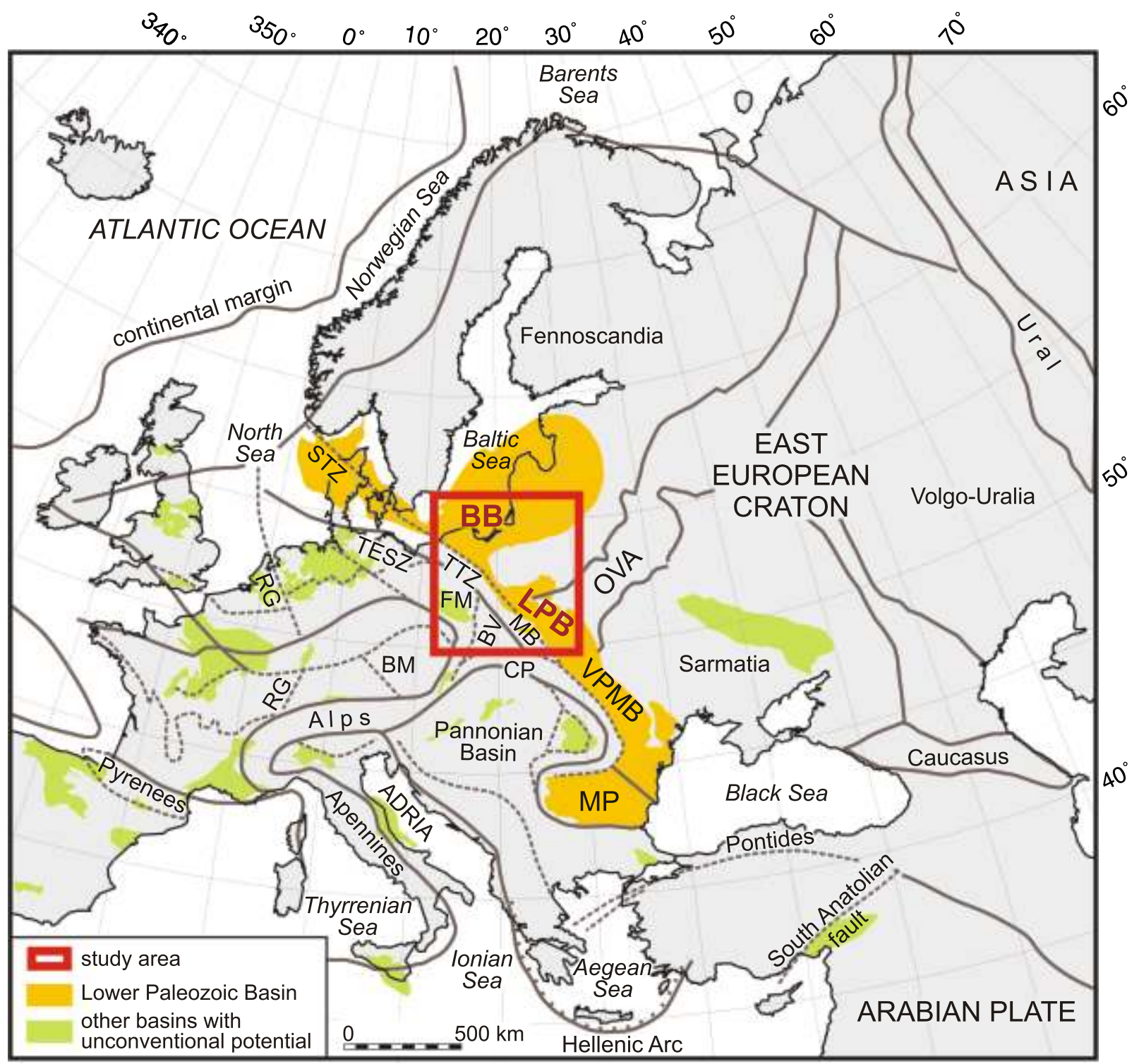

Fig. 1. Simplified tectonic map of Europe (after: Berthelsen, 1992; Jarosiński et al., 2009), with location of the lower Paleozoic Baltic-Dniester Basin after Poprawa (2019)

The other European unconventional shale/tight oil and/or gas basins after EIA (2013), Boros (2014), and Zijp et al. (2017); BB Baltic Basin, BM - Bohemian Massif; BV - Brunovistulian Block, CP - Carpathians, FM - Fore-Sudetic Monocline, LPB Lublin-Podlasie Basin, MB - Małopolska Block, MP - Moesian Platform, OVA - Orsha-Volyn Aulacogen, RG - Rhein Graben, STZ - Sorgenfrei-Tornquist Zone, TESZ - Trans-European Suture Zone, TTZ - Teisseyre-Tornquist Zone, VPMB - Volyn-Podolia-Moldova Basin

rounding countries, focusing on the lower Paleozoic Baltic-Podlasie-Lublin Basin (see Fig. 1 for location), which attracted the major attention of industry. The exploration resulted in 66 new boreholes (see Fig. 2 for location), some of which were tested, intensive coverage of new 2D and 3D seismic data (see Fig. 3 for location), and significant amounts of new wire log and core data. The new dataset is of large volume, extending beyond the capacity of an individual study. Therefore, the current paper overviews only selected key aspects of shale reservoir characteristics, with a degree of generalization. Nonetheless, it allows definition of elements of the geological characteristics that are advantages and risk factors for shale gas/oil exploration in this region.

\section{PETROLEUM GEOLOGY OF THE BALTIC-PODLASIE-LUBLIN BASIN}

The area studied is the western slope of the East European Craton (EEC), where a NW-SE elongated set of genetically connected basins developed during Ediacaran to early Paleo- 


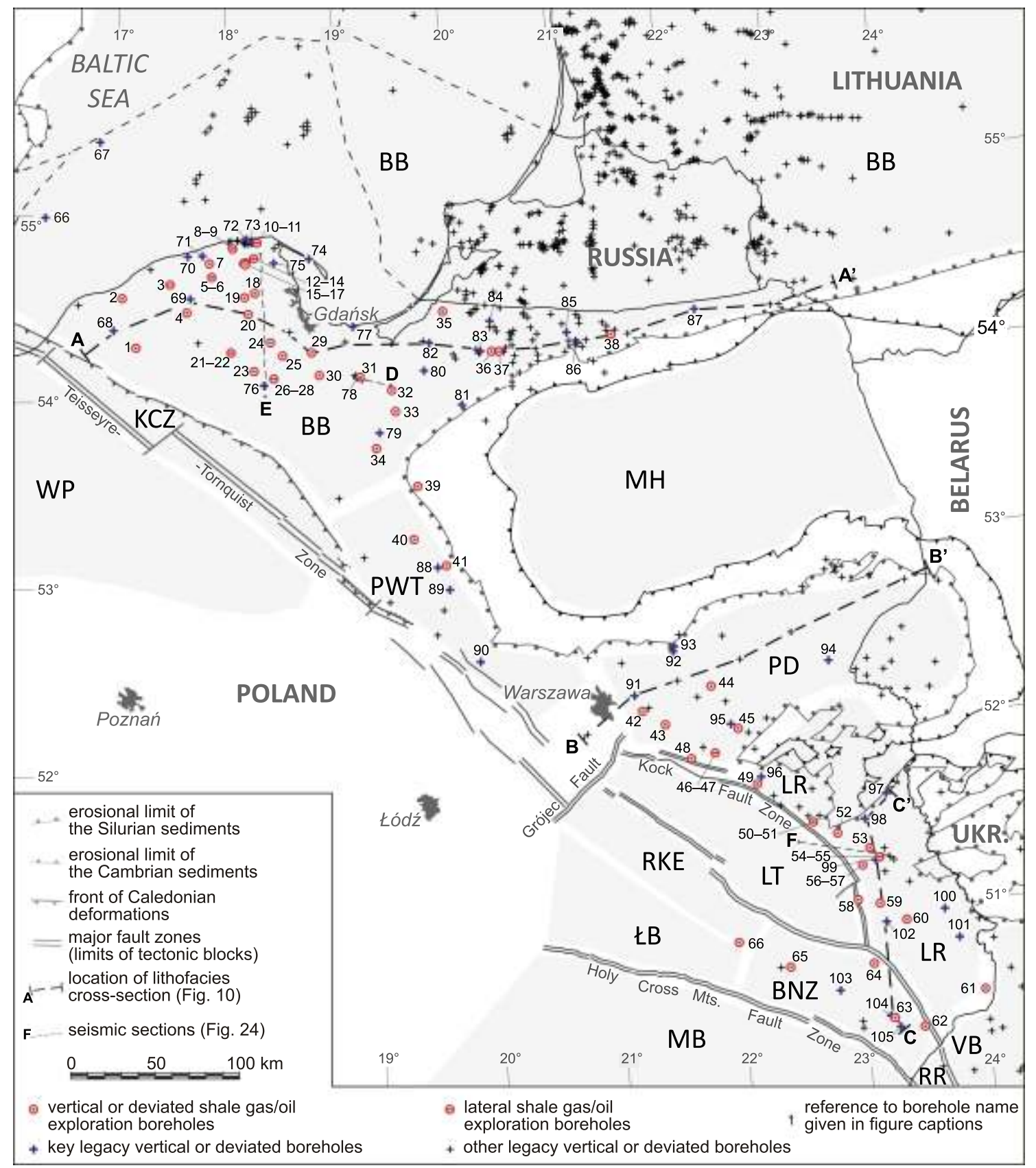

Fig. 2. Location of new shale gas/oil exploration boreholes and legacy lower Paleozoic boreholes in the Baltic-Podlasie-Lublin Basin, the Biłgoraj-Narol Zone, and surrounding areas

BB - Baltic Basin, BNZ - Biłgoraj-Narol Zone, KCZ - Koszalin-Chojnice Zone, LR - Lublin Region (referred to also as the Lublin slope of the EEC), LT - Lublin Trough, ŁB - Łysogóry Block, MB - Małopolska Block, MH - Mazury High, PD - Podlasie Depression, PWT - Płock-Warsaw Trough, RKE - Radom-Kraśnik Elevation, RR - Rawa Ruska Zone, VB - Volyn Basin, WP - Western Pomerania. New boreholes drilled during shale gas/oil exploration. Baltic Basin: 1 - Miszewo T-1 (v), 2 - Wytowno S-1 (v), 3 - Warblino 1H (h), 4 - Lebork S-1 (v), 5 - Łebień LE-1 (v), 6 Łebień LE-2H (h), 7 - Strzeszewo LE-1 (v), 8 - Lublewo LEP-1 (v), 9 - Lublewo LEP-1ST1H (h), 10 - Sławoszyno LEP-1 (v), 11 - Sławoszyno LEP-1ST1H (h), 12 - Lubocino 1(v), 13 - Lubocino 2H (h), 14 - Lubocino 3H (h), 15 - Opalino 2 (v), 16 - Opalino 3 (v), 17 - Opalino 4 (v), 18 Kochanowo 1 (v), 19 - Teppcz 1 (v), 20 - Lewino 1 (v), 21 - Gapowo B-1 (v), 22 - Gapowo B-1A (h), 23 - Będomin 1 (v), 24 - Borcz 1 (v), 25 Miłowo 1 (v), 26 - Wysin 1 (v), 27 - Wysin 2H bis (h), 28 - Wysin 3H (h), 29- Łęgowo LE-1 (v), 30 - Starograd S-1 (v), 31 - Kamionka 1 (v), 32 Bagart 1 (v), 33 - Stare Miasto 1 (v), 34 - KWI Prabuty 1 (v), 35 - Rogity 1 (v), 36 - Mingajny 1 (v), 37 - Babiak 1 (h), 38 - Rodele 1 (v); Płock-Warsaw Trough: 39 - BRO NW Lubawskie 01 (v), 40 - Szymkowo 1 (v), 41 - RYP Lutocin 01 (v); Podlasie Depression: 42 - Pęclin OU1 (v), 43 - Siennica 1 (v), 44 - SOK Grebków 01 (v), 45 - SIE Domanice 01 (v), 46 - Stoczek OU1 (v), 47 - Stoczek OU1K (h), 48 - Goździk OU1 (v); Lublin Basin: 49 - Wojcieszków 1 (v), 50 - Berejów OU1 (v), 51 - Berejów OU2K (h), 52 - Uścimów OU1 (v), 53 - ORZ Cyców 01 (v), 54 Syczyn OU1 (v), 55 - Syczyn OU2K (h), 56 - Stręczyn OU1 (v), 57 - Stręczyn OU1K (h), 58 - Dobryniów OU1 (v), 59 - Krupe 1 (v), 60 Grabowiec 6 (v), 61 - Kościaszyn 1 (v); Biłgoraj-Narol Zone: 62 - Lubycza Królewska 1 (v), 63 - Majdan Sopocki 1 (v), 64 - Zwierzyniec 1 (v), 65 - Frampol 1 (v), 66 - Kraśnik 1 (v). (v) - vertical or deviated borehole, (h) - lateral borehole. Key legacy boreholes (vertical or deviated). Baltic Basin: 66 - A8-1/83, 67 - A23-1/88, 68 - Słupsk IG 1, 69-Lebork IG 1, 70-Łeba 8, 71-Lubiny 1, 72 - Debki 4, 73 - arnowiec IG 1, 74 - Hel IG 1,75-Dar lubie IG 1, 76 - Kościerzyna IG 1, 77-Gdańsk IG 1, 78-Malbork IG 1, 79-Prabuty IG 1, 80-Pasłęk IG 1, 81 - Olsztyn IG 2, 82 - Młynary 1, 83 - Henrykowo 1, 84 - Dębowiec Warmiński 2, 85 - Bartoszyce IG 1, 86 - Kętrzyn IG 1, 87 - Gołdap IG 1; Płock-Warsaw Trough: 88 - Szczawno 1, 89 - Polik IG 1, 90 - Bodzanów IG 1; Podlasie Depression: 91 - Okuniew IG 1, 92 - Tłuszcz IG 1, 93 - Łochów IG 2,94 Mielnik IG 1, 95 - ebrak IG 1; Lublin Basin: 96 - Siedliska IG 1, 97 - Kaplonosy IG 1, 98 - Krowie Bagno IG 1, 99 - Busówno IG 1, 100 Bialopole IG 1, 101 - Terebin IG 5, 102 - Łopiennik IG 1; Biłgoraj-Narol Zone: 103 - Dyle IG 1, 104 - Narol PIG 2, 105 - Narol IG 1 
zoic time (e.g., Gareckij et al., 1987; Poprawa, 2006a, b; Šliaupa et al., 2006; Poprawa et al., 2018a; Fig. 1). This system of sedimentary basins is referred to as the Peri-Tornquist Basins (Poprawa et al., 1999; Sliaupa et al., 2006), or alternatively as the Baltic-Dniester Basins (Poprawa, 2019). The central part of this system is composed of the Baltic Basin and the Lublin-Podlasie Basin, sometimes together alternatively referred to as the Baltic-Podlasie-Lublin Basin (Poprawa, 2010a; PGI, 2012), being a subject of the current study. To the north-west it passes into the Scandinavian slope of the EEC (Vejbæk et al., 1994; Greiling et al., 1999; Nielsen and Schovsbo, 2010), and to the south-east into the Volyn-Podolia-Moldova Basin, alternatively referred to as the Dniester Basin (Gautier et al., 2012; Sachsenhofer and Koltun, 2012; Radkovets, 2015; Poprawa et al., 2018a). Farther south the system of lower Paleozoic basins continues into the Moesian Platform (Fig. 1; Popescu and Anastasiu, 2016; Schovsbo et al., 2017).

From the south-west this large system of sedimentary basins is limited by the Trans-European Suture Zone (TESZ), while their northeastern limit is usually of erosional nature. Within the TESZ, other tectonic blocks are developed with the lower $\mathrm{Pa}$ leozoic sedimentary cover (Fig. 2). The position adjacent to the west of the Baltic Basin is occupied by the Koszalin-Chojnice Zone (Podhalańska and Modliński, 2006; Poprawa, 2006b). To the west of the Lublin-Podlasie Basin, the Biłgoraj-Narol Zone, in Ukraine referred to as the Rava Ruska Zone, is located (Modliński and Szymański, 2005; Drygant et al., 2006; Radkovets, 2015; Poprawa, 2019). The northwestern extension of this unit is the Łysogóry Unit, and farther west the Małopolska Block is positioned (Fig. 2). Apart from the Baltic Basin and the Lublin-Podlasie Basin, this paper covers also the development of the Biłgoraj-Narol Zone, while the Małopolska Block and the Koszalin-Chojnice Zone are discussed here only marginally.

The Baltic-Podlasie-Lublin Basin is divided into two separate petroleum provinces: in the north the Baltic Petroleum Province, and in the south the Lublin Petroleum Province (Karnkowski, 1997; Poprawa et al., 2018b). The Lublin Petroleum Province comprises only a few small oil and gas fields, all in clastic and carbonate reservoirs of the Carboniferous and Devonian succession (Karnkowski, 1999; Niedbalec and Radecki, 2007). Nonetheless, biomarker studies indicated oil origin from Silurian source rock (Klimuszko, 2002). No oil and gas fields have been discovered in the lower Paleozoic succession of the Lublin Petroleum Province, although hydrocarbon shows have been observed there (Stolarczyk et al., 1997; Pacześna et al., 2005).

In the Baltic Petroleum Province numerous small to midsize hydrocarbon fields, mostly oil fields, and less commonly condensate fields, have been discovered (Ulmishek, 1990; Brangulis et al., 1993; Jacyna et al., 1997; Karnkowski, 1999; Doornenbal and Stevenson, 2010). The key reservoir rock is middle Cambrian sandstone, while Lower to Middle Ordovician carbonates, as well as Upper Ordovician to Silurian carbonate build-ups, are subordinate reservoirs (Fig. 4; Jacyna et al., 1997; Dom alski et al., 2004; Stolarczyk et al., 2004; Kaminskas et al., 2015; Levendal et al., 2019). Reservoir properties of the middle Cambrian sandstone depend solely on the degree of quartz cementation (Sikorska, 1998; Molenaar et al., 2007; Semyrka et al., 2010). The Cambrian conventional reservoir in the central and southwestern part of the Baltic Basin passes into tight reservoir development (Poprawa and Kiersnowski, 2008; Wójcicki et al., 2014). In the Lublin Petroleum Province, the lower Paleozoic potential conventional reservoir rock is the middle Cambrian sandstone (Stolarczyk et al., 1997; Pacześna et al., 2005).

Historically, the upper Cambrian and/or lower Tremadocian shale (Piaśnica Formation) was regarded as the main hydrocar- bon source rock in the Baltic Petroleum Province (Fig. 4; Kanev et al., 1994; Karnkowski, 1999; Yang et al., 2017). However, recent studies indicate that the Upper Ordovician (Sasino Formation) and the lower Llandovery (Jantar Formation) shale also have a significant role as source rock (Poprawa, 2010a; Więcław et al., 2010). Moreover, in the eastern Baltic Basin, the Mingajny shale (uppermost Llandovery to lower Wenlock) might be regarded as a fair hydrocarbon source rock (Fig. 4). The lateral equivalents of the Sasino and Jantar formations and the Mingajny shale are regarded as source rocks in the Lithuanian and Latvian part of the basin (Kanev et al., 1994; Kadūnienè, 2001; Zdanaviciute and Lazauskiene, 2007; Zdanavičiūtè and Lazauskienè, 2009; Sliaupa et al., 2016; Cichon-Pupienis et al., 2020). In the Lublin Petroleum Province the potential source rocks comprise Caradoc and Llandovery shales, present in the northern and/or central part of the province, as well as the lower Wenlock Mingajny shale. The later one is characterized by lower quality, though higher net thickness as well as broader lateral extent. Wenlock shale of such development extends farther to the south-east to the Volyn-Podolia Basin (Sachsenhofer and Koltun, 2012; Radkovets, 2015; Radkovets et al., 2017; Schovsbo et al., 2017). Apart from this, the uppermost Ediacaran black shale may be regarded as a low quality potential source rock in the Lublin region (Pacześna et al., 2005), as well as in the VolynPodolia Basin (Radkovets et al., 2018).

Most of the oil and condensate fields in the Baltic Province are developed in structural traps, being anticlines related to reverse faults (faulted anticline play) (Jacyna et al., 1997; Poprawa et al., 2006; Karnkowski et al., 2010). The faults developed during two phases of compression and/or transpression: the late Caledonian (Lochkovian) and the late Variscan (late Carboniferous; Fig. 4; Poprawa et al., 2006). Less commonly, oil fields occur in stratigraphic traps (pinch-out play, drape/onlap play, deeply weathered crystalline basement play), as well as in lithological traps (reef play, and inter-reef/back-reef play) (Jacyna et al., 1997; Lapinskas, 2000; Kaminskas et al., 2015). The regional seal is a thick unit of Upper Ordovician and Silurian shale, and in the central and southwestern part of the basin also Zechstein evaporites (Fig. 4). The structural and stratigraphic traps are locally sealed by middle Cambrian mudstone, while the cap rock for the stratigraphic traps is Upper Ordovician and Silurian shale (Fig. 4). Similar formations act as a potential seal also in the Lublin Petroleum Province, except for the Zechstein evaporites, present there only in the northwestern part of that region (Wagner, 1994).

The burial history of the Baltic Province is characterized by three phases of significant subsidence: in the late Silurian, Devonian to early Carboniferous, and Permian-Mesozoic (Fig. 4), interspersed with late Caledonian and late Variscan tectonic uplift and denudation (Poprawa et al., 2010). The maximum burial is either of Variscan age, mainly Devonian, or of late Mesozoic to recent age (Poprawa and Grotek, 2005). Initial hydrocarbon generation took place during late Silurian burial, while its main phase occurred either in the Devonian to early Carboniferous (Kosakowski et al., 2010), or in the late Mesozoic (Poprawa and Grotek, 2005; Fig. 4). The Devonian to early Carboniferous and the late Mesozoic are alternative times for critical moment to occur. Development of petroleum traps and hydrocarbon generation in general predates the critical moment. The exception is hydrocarbons generated during the Devonian to early Carboniferous, migrating prior to development of the late Variscan traps (Fig. 4). This part of the hydrocarbon load might therefore be lost.

The burial history of the Lublin-Podlasie Basin is more complex. Depending on location, the maximum burial time might be of latest Devonian, late Carboniferous or late Mesozoic age (Poprawa and ywiecki, 2005). However, the main phase of hydrocarbon generation took place during Devonian or Carbonifer- 


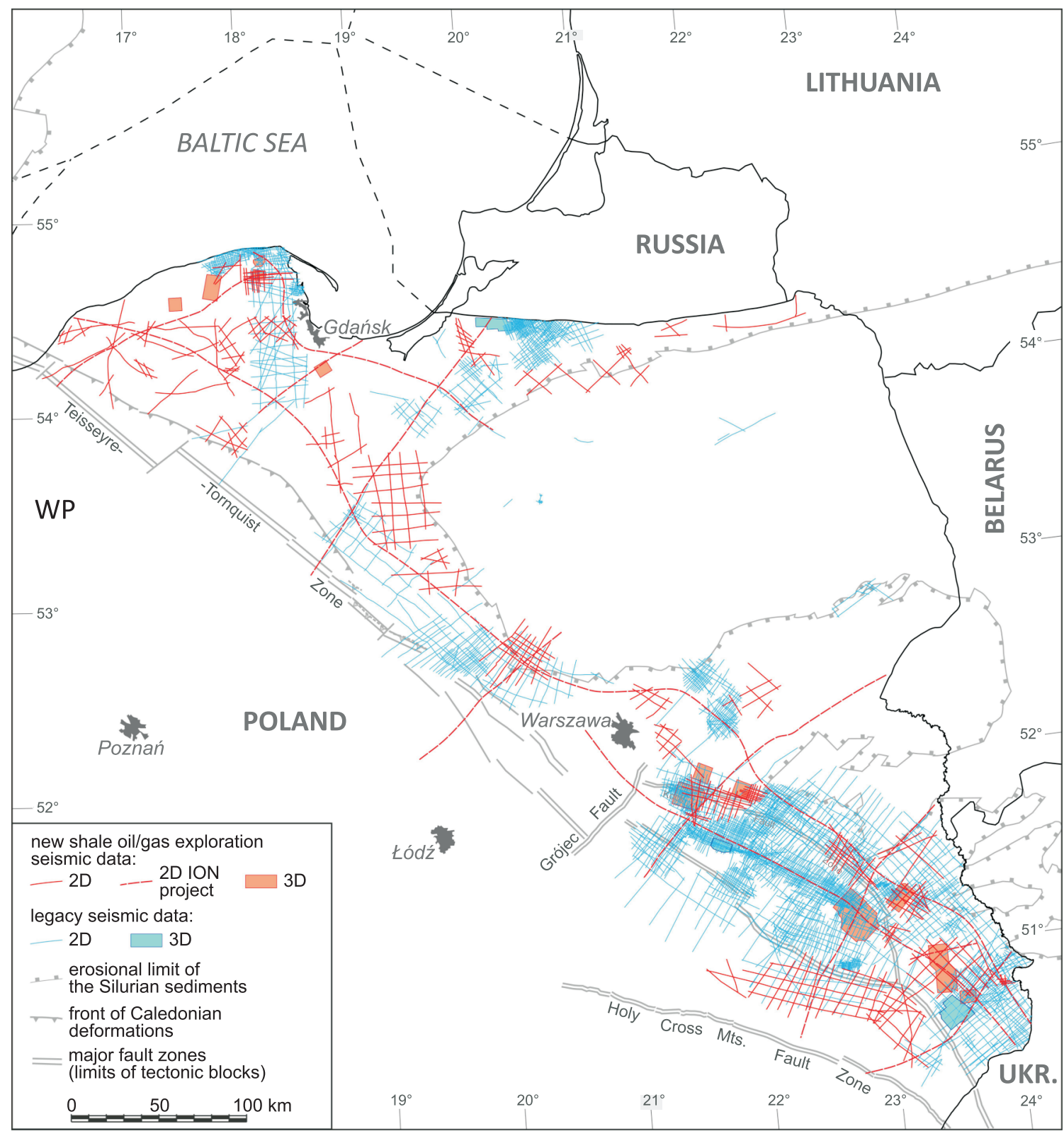

Fig. 3. Location of legacy $2 \mathrm{D}$ and 3D seismic data, and of new 2D and 3D seismic data acquired during shale gas and shale oil exploration in the Baltic-Podlasie-Lublin Basin, the Biłgoraj-Narol Zone, and surrounding areas

Explanations to tectonic units as in Figure 2; 2D ION project - regional, deep reflection high-end seismic survey of PolandSPAN ${ }^{\mathrm{TM}}$ project operated by ION

ous time (Botor et al., 2002; Prugar, 2013), particularly in the case of a lower Paleozoic source rock. The critical moment in this basin is, therefore, either latest Devonian, or late Carboniferous.

Apart from conventional hydrocarbon plays, the total petroleum system of the Baltic and Lublin provinces comprises also an unconventional lower Paleozoic shale play (e.g., Poprawa and Kiersnowski, 2008; Zdanavičiūtè and Lazauskienè, 2009; Poprawa, 2010a, b; Gautier et al., 2012; Kiersnowski, 2013; Kiersnowski and Dyrka, 2013; Porębski et al., 2013; Wójcicki, 2015; Podhalańska et al., 2016; Tari et al., 2016; Papiernik et al., 2017; Cichon-Pupienis et al., 2020). This play is developed in the Caledonian foredeep basin (Poprawa, 2010a), being a typical tectonic setting for unconventional oil/gas fields - foredeep basins account for roughly $55 \%$ of the global total unconventional oil/gas resources (Wang et al., 2016). The lower Pa- leozoic shale play in the Baltic-Podlasie-Lublin Basin and the adjacent area is a subject of interest for the current paper, and is discussed below.

\section{SHALE OIL/GAS EXPLORATION IN THE BALTIC-PODLASIE-LUBLIN BASIN}

Shale gas and shale oil exploration in Poland has been concentrated solely on the lower Paleozoic Baltic-Podlasie-Lublin Basin. Since 2007 until 2013, during the Polish "shale rush", a total of 95 exploration concession blocks were granted to 19 operators, covering nearly the whole area analysed (Fig. 5). Within the Baltic-Podlasie-Lublin Basin, the acreage which missed 


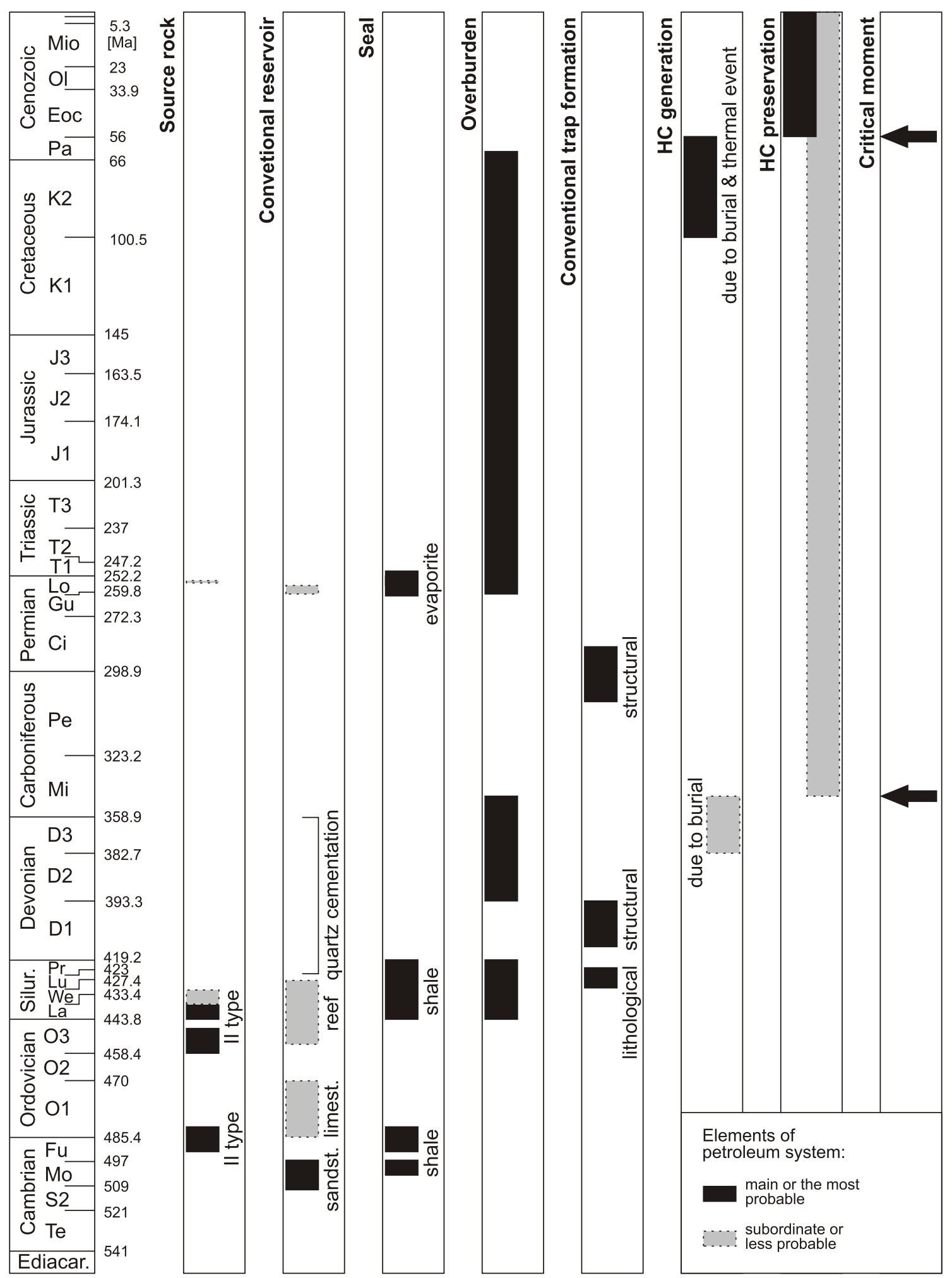

Fig. 4. Petroleum system chart for the lower Paleozoic Baltic Basin

Mio - Miocene, OI - Oligocene, Eoc - Eocene, Pa - Paleocene, K - Cretaceous, J - Jurassic, T - Triassic, Lo Lopingian, Gu - Guadalupian, $\mathrm{Ci}$ - Cisuralian, Pe-Pennsylvanian, Mi-Mississippian, D - Devonian, Silur. - Silurian, $\mathrm{Pr}$ - Pridoli, Lu - Ludlow, We - Wenlock, La - Llandovery, O - Ordovician, Fu - Furongian, Mi - Miaolingian, S2 - Series 2, Te - Terreneuvian, Ediacar. - Ediacaran. Numerical ages after Cohen et al. (2013) 


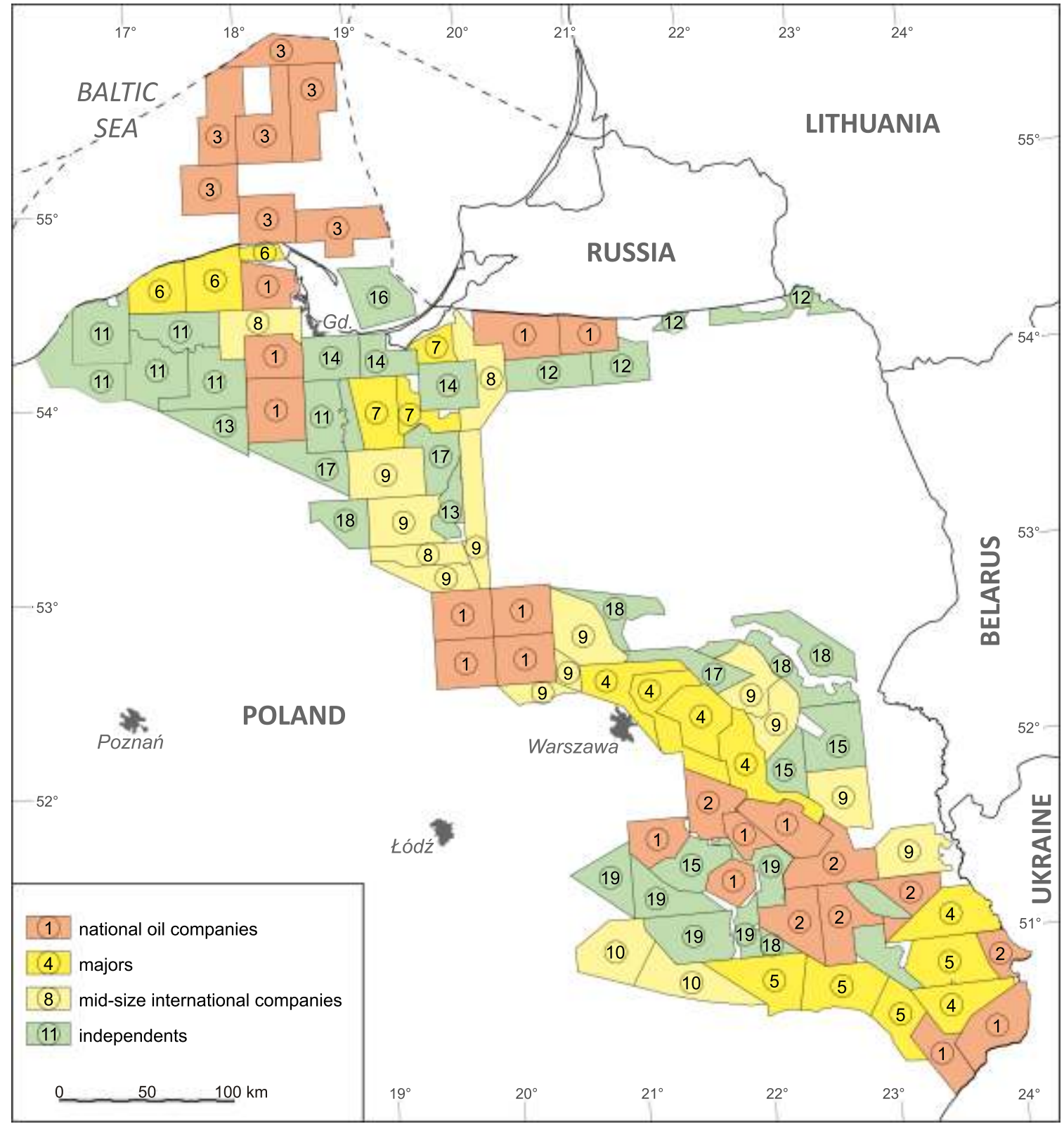

Fig. 5. Shale gas and shale oil exploration concessions in the Baltic-Podlasie-Lublin Basin, the Biłgoraj-Narol Zone, the Łysogóry Block, and surrounding areas

National Oil Companies (NOC): 1 - POGC, 2 - Orlen Upstream, 3 - Lotos Petrobaltic. Majors: 4 - ExxonMobil, 5 - Chevron, 6 - ConocoPhillips, 7 - ENI. Mid-size international companies: 8 - Talisman, 9 - Marathon, 10 - ClOC. Independents: 11 - BNK, 12 - Wisent, 13 - San Leon, 14 - Lane, 15 - Cuadrilla, 16 - EurEnergy, 17 - Realm, 18 - Petrolinvest, 19 $-\mathrm{DPV}$

shale gas/oil exploration was the northeastern Lublin region, the eastern part of the Podlasie Depression and parts of the eastern limits of the onshore Baltic Basin, all characterized by a low thermal maturity. Moreover, exploration was not conducted in the southwestern limits of the Baltic Basin and the Podlasie Depression, or in the Lublin Trough to the west of Kock Fault Zone, these being overmature. A major part of the offshore Baltic Basin also avoided exploration for unconventional oil/gas due to highly challenging economic conditions. The operators were roughly equally divided between Polish national oil companies, the majors and mid-size companies, and the independents (Fig. 5).
The significant amount and diversity of the operators active in this region resulted in a substantial amount of new geological data being produced, and with a variety of exploration strategies applied. The key outcome of the exploration was many new boreholes (Figs. 2 and 6), high quality wire logs, and core/cutting samples, being subject to a broad programme of laboratory analysis. This data allowed for significant progress of petroleum geology in the area discussed area, but also promoted advances in the pure geological sciences.

Drilling activity in the lower Paleozoic shale prospect in Poland, initiated in mid-2010, accelerated significantly during 2011-2014, and ceased thereafter (Fig. 6). In 2010 - 5 shale 


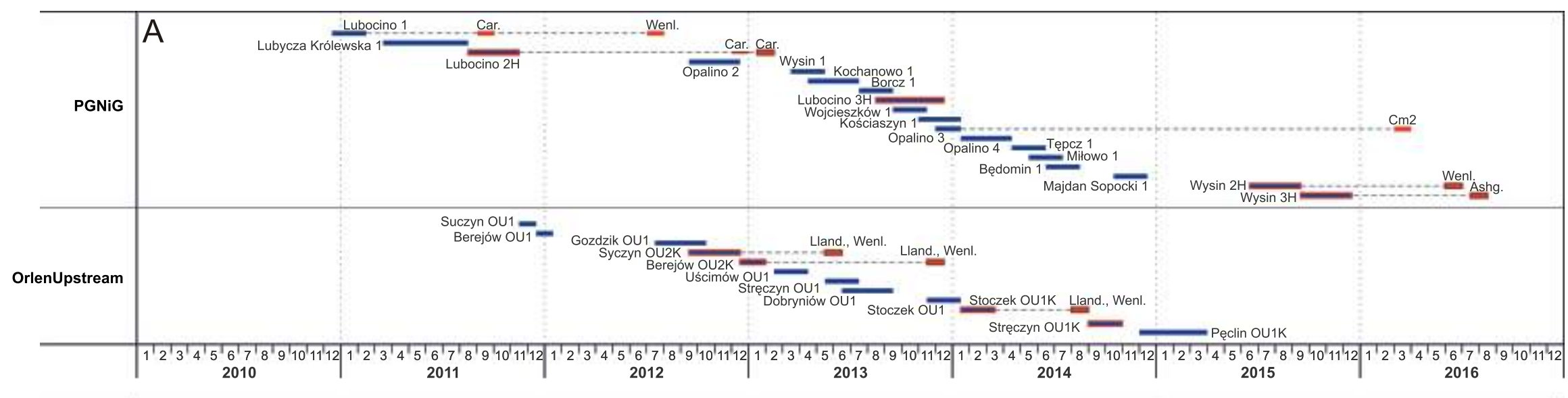

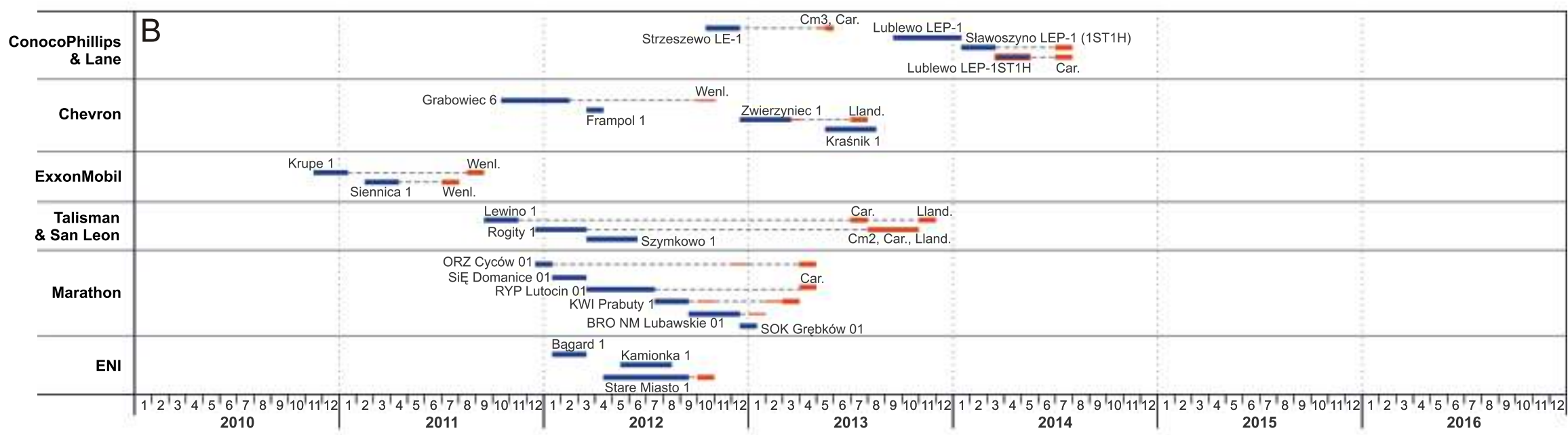

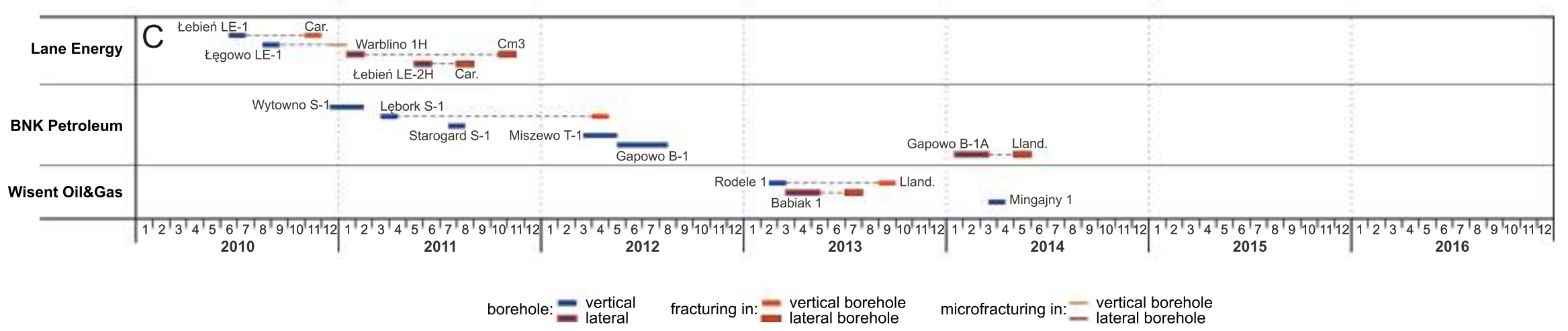

Fig. 6. History of shale gas/oil exploration in the Baltic-Podlasie-Lublin Basin and the Biłgoraj-Narol Zone: drilling and hydraulic fracturing

A - national oil companies, B - majors and mid-size international oil companies, C - independents; stratigraphy of fractured interval: Cm2 - middle Cambrian, Cm3 - upper Cambrian (Piaśnica Fm.), Car. - Caradoc, Ashg. - Ashgill, Lland. - Llandovery, Wenl. - Wenlock 
gas/oil exploration boreholes were spudded, in 2011 this was 13 boreholes, in 2012 - 18 boreholes, in 2013 - 15 boreholes, in $2014-13$ boreholes, and the last 2 boreholes were spudded in 2015. Exploration ceased in 2016, when the last hydraulic fracturing and well tests were completed (Fig. 6). The early pioneers of drilling were the independents, followed by the majors, and afterwards by the national oil companies (Fig. 6). New exploration boreholes were spread across the whole area analysed; however, their highest concentration was in the Baltic Basin, while the Podlasie Depression was an area of the lowest activity (Fig. 2). In the Lublin region exploration activity concentrated in its central part.

The new data owing to shale gas/oil exploration in many cases filled blank spots in geological map of the study area. In the Baltic Basin, the majority of the 38 new exploration boreholes were located in the central, western and southwestern part of the basin, previously characterized by sparse coverage of deep boreholes (Fig. 2). The same is true for the Płock-Warsaw Trough, where three new boreholes doubled the amount of legacy deep key boreholes, as well as for the western Podlasie Depression, where seven new boreholes were drilled. In the Lublin region, altogether thirteen shale gas/oil exploration boreholes were sited, which filled significant gaps between the legacy deep boreholes, particularly in the southern part of the region. In the Biłgoraj-Narol Zone, the lower Paleozoic succession was recognized previously with three deep key boreholes, while shale gas exploration in that zone resulted in five new boreholes (Fig. 2). Some of new boreholes considerably updated knowledge of the geological setting of the area. An example is the BRO Nowe Miasto Lubawskie 01 borehole, the outcome of which was a significant westwards shift of the limit of the Mazury High (Fig. 2; Poprawa, 2019). Another is the Kraśnik 1 borehole, which documented 454 m of Visean strata in the southern part of the Radom-Kraśnik Elevation, which in general is characterized by an absence of Carboniferous deposits (Poprawa, 2019).

The shale gas/oil exploration also considerably changed the seismic coverage of the Baltic-Podlasie-Lublin Basin and the Bitgoraj-Narol Zone. This is in particular true for the Baltic Basin (Fig. 3). New 2D seismic lines densely cover the area of the eastern, southern and western part of the basin, previously nearly devoid of seismic data. Moreover, in the central and western parts of the basin, 5 new 3D surveys were acquired. Considerable progress in seismic coverage was obtained also in the central and western Podlasie Depression (Fig. 3). Apart from the $2 \mathrm{D}$ seismic data, three 3D surveys were acquired there. The Lublin region was characterized by a very dense grid of $2 \mathrm{D}$ seismic prior to shale gas/oil exploration, nonetheless, four new 3D surveys, some of which are very large, brought further progress in revealing the subsurface geological structure (Fig. 3). High quality, up-to-date 2D seismic data was acquired also along several lines in the Narol-Biłgoraj Zone.

Of particular value was the regional, deep reflection highend seismic survey of the PolandSPAN ${ }^{\mathrm{TM}}$ project, operated by ION (Fig. 3). This dataset was measured with long recording time $-12 \mathrm{~s}$, high nominal fold -480 , long offsets $-12 \mathrm{~km}$, tight receiver/shot spacing - $25 \mathrm{~m}$, and broadband sweep 2-150 Hz (Krzywiec et al., 2014). It allowed fine-tuning of the reconstructed evolution of the Caledonian foredeep basin at the western slope of the EEC (Krzywiec et al., 2014; Poprawa, 2019). Moreover, it revealed the presence of a large, upper Ediacaran extensional, rift-related half-graben in the Lublin region (Krzywiec et al., 2018), as well as the presence of Variscan thrust sheets in the Biłgoraj-Narol Zone (Krzywiec et al., 2017).

During the shale gas/oil exploration, altogether 66 new boreholes were drilled in the area discussed, although most of them were vertical boreholes. Among this number only 13 boreholes were lateral ones, while 10 lateral boreholes were used for multistage hydraulic fracturing and related production tests (Fig. 7). In addition, hydraulic fracturing and production tests were performed in 16 vertical boreholes, and in a further 3 boreholes the completion was limited to microfracturing (DFIT).

Statistics of hydraulic fracturing and microfracturing of vertical and lateral boreholes are given in Figure 6. A significant proportion of the exploration boreholes experienced considerable mechanical problems during drilling and/or fracturing, typical of the early stage of an exploration/production learning curve. As a consequence, across the area analysed there are only 5 lateral boreholes with multi-fracturing, which were not junked, or at least avoided significant damage, and gave reliable results of production tests (Fig. 7). Therefore, despite a decade of intensive exploration, the shale gas/oil play in the Baltic-Podlasie-Lublin Basin could still be regarded as significantly underexplored.

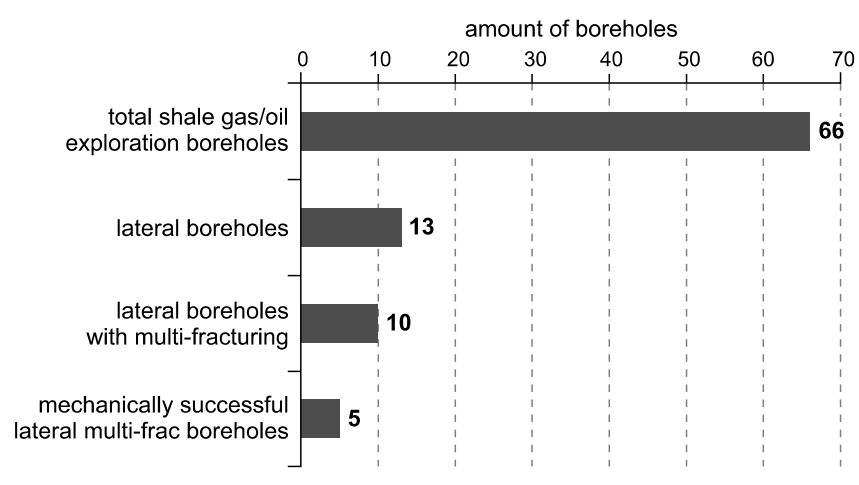

Fig. 7. Statistics of new shale gas/oil exploration boreholes drilled in the lower Paleozoic Baltic-Podlasie-Lublin Basin and the Biłgoraj-Narol Zone, with division into lateral and vertical boreholes, as well as into mechanically successful versus junked boreholes (after Poprawa et al., 2018b, modified)

\section{TECTONIC AND FACIES FRAMEWORK OF THE UNCONVENTIONAL PETROLEUM PLAY}

Tectonic processes governing the development of the Ediacaran to lower Paleozoic basins on the western slope of the EEC controlled to a large extent the key elements of the unconventional hydrocarbon play, in particular the facies architecture, lateral and vertical distribution of total organic carbon (TOC) content, as well as the thermal maturity and hydrocarbon generation history. The tectonic evolution of the area is discussed here briefly, based on published data (e.g., Poprawa, 2019), only to the extent necessary to constrain the shale gas/oil potential of the analysed area.

The evolution of the Baltic-Dniester system of sedimentary basins, covering the western slope of the EEC, initiated with late Ediacaran rifting (Fig. 8). The rifting is expressed with the indicative pattern of tectonic subsidence and the presence of a subsequent post-rift basin (Poprawa et al., 1999, 2018a; Poprawa and Pacześna, 2002; Poprawa, 2006a, b; Eriksson, 2012). Moreover, it is shown by the development of the large-scale extensional half-grabens (Lassen et al., 2001; Krzywiec et al., 2018), and rift-related magmatic activity (Fig. 8B; Bakun-- 


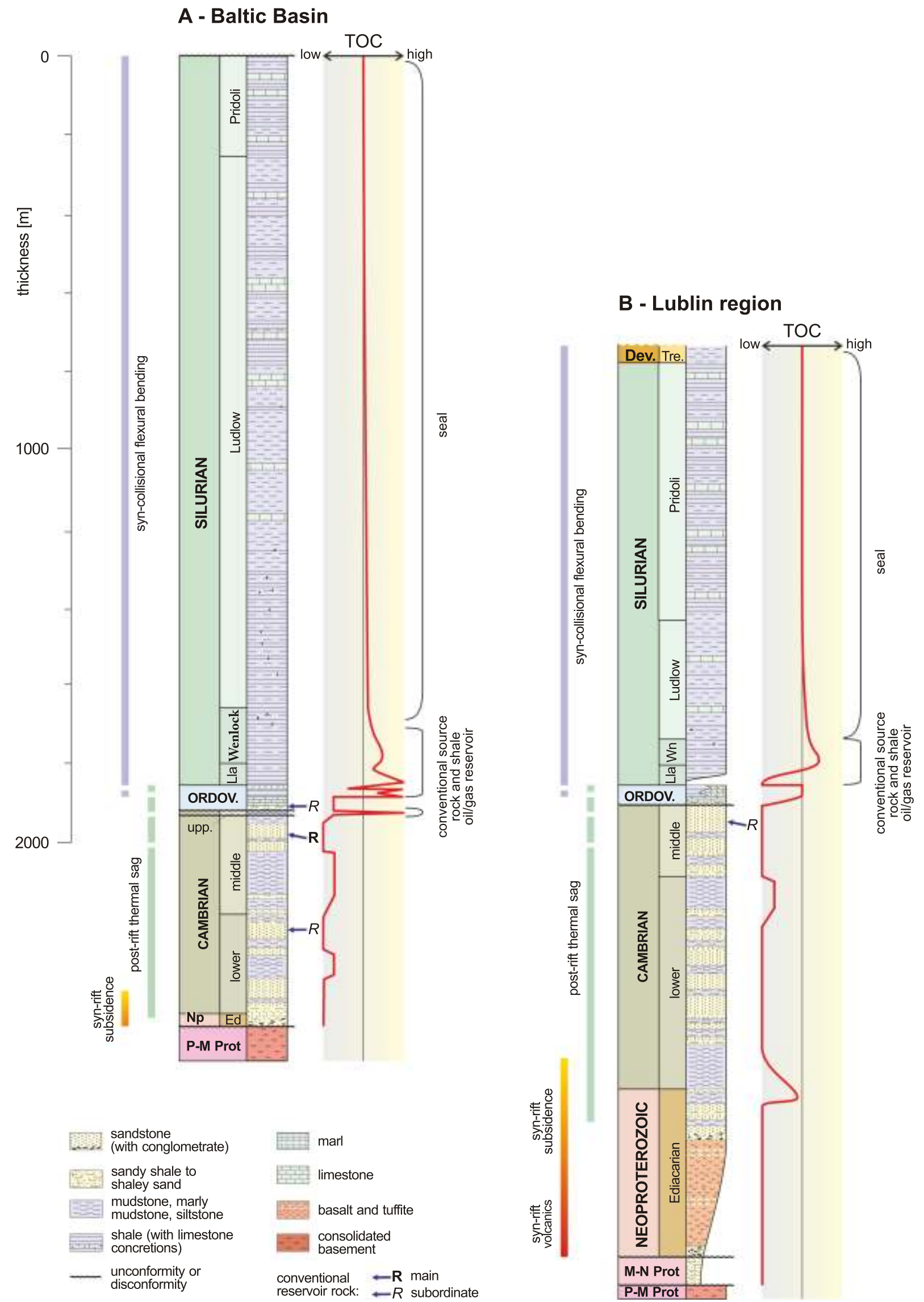

Fig. 8. Simplified lithostratigraphic sections of the Neoproterozoic and lower Paleozoic in (A) the Baltic Basin, and $(B)$ the Lublin region, with position of organic-rich shale (after: Poprawa, 2010a, modified)

Subsidence mechanisms after Poprawa and Pacześna (2002) and Poprawa (2006a, b). Dev. - Devonian, Tre - Tremadocian, $\mathrm{Wn}$ - Wenlock, Lla - Llandovery, Ed - Ediacaran, M-N Prot - Mesoproterozoic and Neoproterozoic, P-M Prot - Paleoproterozoic and Mesoproterozoic 
Czubarow et al., 2002; Emetz et al., 2004; Krzemińska, 2005; Poprawa et al., 2020). The rift origin of the basin analysed is supported also by characteristic Ediacaran to lowermost Cambrian facies development, with evolution from continental conglomerates to marine clastic sediments, and grain size generally fining up-section (Fig. 8B; Poprawa and Pacześna, 2002; Pacześna, 2006, 2014).

The latest Ediacaran to Late Ordovician tectonic subsidence pattern of the area analysed is typical of the thermal sag stage of extensional basins (Fig. 8; Poprawa et al., 1999, 2018a; Poprawa and Pacześna, 2002; Poprawa, 2006a; Sliaupa et al., 2006; Eriksson, 2012). This conclusion is supported by a gradual lateral expansion of the sedimentary basin at the western slope of the EEC during the time span discussed (Poprawa and Pacześna, 2002). Following the rifting, the break-up of the Precambrian supercontinent and the development of the Tornquist Ocean, the southwestern margin of the newly formed Baltica became the latest Ediacaran to Middle Ordovician passive continental margin (Poprawa, 2006a). It was a site of shallow marine siliciclastic, and later carbonate sedimentation (Paškevičius, 1997; Modliński et al., 2010; Figs. 9 and 10).

During the latest Cambrian and earliest Ordovician, the thermal sag stage was interrupted by a phase of uplift and erosion along the Lublin-Podlasie Basin and the Volyn-PodoliaMoldova Basin (Figs. 9 and 11A, B), inconsistent with the model of a passive margin (Poprawa, 2006a; Poprawa et al., 2018a). This process was interpreted as being a result of compressional stress, related to oblique docking of the Małopolska Block to Baltica (Poprawa, 2006a). Following that, the upper Cambrian and lowermost Ordovician basin at the Biłgoraj-Narol Zone and the Łysogóry Block could be regarded as a small-scale narrow flexural foredeep. In this tectonic context, the Tremadocian Goraj Member shale (Modliński and Szymański, 2005), one of the potential shale gas reservoirs, was deposited in the Biłgoraj-Narol Zone (Figs. 9E and 11B; Poprawa et al., 2016). Farther north, in the northwestern part of the Baltic Basin, organic-rich shale of upper Cambrian-Tremadocian age, referred to as the Piaśnica Formation (Figs. 9A and 11A; Szymański, 2008), was deposited in a restricted basin. This formation is both one of the major conventional hydrocarbon source rocks (Kanev i in., 1994; Więcław et al., 2010; Yang et al., 2017) and a potential shale gas/oil reservoir. Moreover, during the early Tremadocian the organic-rich shale of the Białowie a Formation was deposited in the northeastern part of the Podlasie Depression (Figs. 9C and 11B; Modliński and Szymański, 2008; Kosakowski et al., 2016). An important factor supporting the development of high organic matter content in shales of the Piaśnica Formation, the Białowie a Formation and the Goraj shale Member, was the late Cambrian and Tremadocian eustatic sea level rise (Fig. 8).

Since the Late Ordovician, a gradual change to a collisional tectonic setting is inferred across the southwestern margin of Baltica, being a consequence of the oblique collision of Avalonia and Baltica (e.g., McKerrow and Cocks, 1986; Cocks, 2000). The collision led to development of the Late Ordovician to Silurian (-Lochkovian?) Caledonian flexural foredeep on the western slope of the EEC (Fig. 7; Poprawa et al., 1999, 2018a; Lazauskienè et al., 2002, 2003; Poprawa, 2006b; Tari et al., 2016; Mazur et al., 2018). During this time span, the key organic rich shale formations were deposited in the Baltic Basin, the Lublin-Podlasie Basin and the Biłgoraj-Narol Zone (Figs. 8 and 9). Tectonic processes governed both development of the plate westwards flexure (Fig. 10) and the sediment supply to the basin from the collision zone, therefore, and controlled facies distribution within the basin (Fig. 11C-H) and also the quality of the oil/gas shale reservoir.

The Caledonian flexural foredeep on the SW slope of the EEC evolved in a way typical of foredeep basins. In the first stage of flexure, a starved basin developed (Poprawa, 2019), promoting organic-rich shale deposition (Fig. 11C, E). With time, increasing detritus supply brought the basin into an overfilled stage, in this case characterized by the development of organic-lean shale and marl (Fig. 11G, H).

In the Baltic-Podlasie-Lublin Basin, there is a clear relation between the rate of sediment deposition and the average TOC content (Fig. 12; Poprawa, 2010a). During the Late Ordovician and early Silurian, the rate of deposition of fine-grained sediments increased gradually with time. In the Baltic Basin, the deposition rate during the Caradoc and Llandovery was generally $<5-10 \mathrm{~m} / \mathrm{My}$. In the Wenlock it increased to $40-50 \mathrm{~m} / \mathrm{My}$, except for the western part of the Baltic Basin which had a very high deposition rate and a lack of organic-rich shale. Significantly higher deposition rates are observed in the Ludlow (200-300 m/My), while in the Pridoli they reach extreme values locally exceeding 1500 m/My (Fig. 12; Poprawa, 2006b). Gradual significant decrease of TOC content in the fine-grained clastic sediments, coeval with increasing deposition rate, was caused primarily by dilution of organic matter within increasing volumes of detritus brought to the basin. Due to this, the zones with high TOC content generally coincide with facies dominated by fine-grained claystone and mudstone, slowly deposited in a deeper, poorly oxygenated environment (Figs. 10 and 11). Towards the west, where influx of detritus from the Caledonian collision zone resulted in the development of mudstone facies, and rarely siltstone and sandstone facies, the TOC content significantly decreases (Fig. 11C-F).

Oblique character of the collision induced a prominent diachronism of the foredeep basin development. This refers to the timing of initiation of plate bending, the onset of rapid subsidence, the first derivation of detritus from the eroded collision zone, as well as the initiation of post-collisional uplift and erosion, with their generally earlier appearance in the north-west of the Baltic Basin, and a systematic migration towards the south-east, to the Lublin-Podlasie Basin and the VolynPodolia-Moldova Basin (Poprawa, 2019). Moreover, the diachronism refers to the starved and the overfilled stages of the foredeep basin development, and therefore caused prominent diachronism of organic-rich shale deposition in the study area (Fig. 13; Poprawa, 2010a; Kiersnowski and Dyrka, 2013). In the central and northwestern parts of the Baltic Basin, deposition of a shale enriched in organic matter begun during the latest Middle Ordovician and continued until the early Ashgill, while by the Llandovery the TOC content of the shale declined (Figs. 11C-E and 13). No Wenlock shale with elevated TOC content is observed in this area (Fig. 11F). Towards the east, in the vicinity of Gdańsk, the onset of organic-rich shale deposition took place during the Caradoc, while the highest TOC content is observed there in the lower Llandovery (Rhuddanian) shale (Fig. 13). Farther east and south-east, in the eastern Baltic Basin and in the western Podlasie Depression, organic-rich shale deposition began in the late Rhuddanian, and continued to the early Wenlock, while in the Lublin region and the Volyn-Podolia-Moldova Basin, deposition of sediments of this type was restricted to the Wenlock, and in the later region also to the earliest Ludlow (Fig. 13).

In the Caledonian foredeep basin on the southwestern slope of the EEC, a characteristic general facies zonation developed (Fig. 11C-H; Modliński et al., 2010; Dziadzio et al., 2017; Porebski and Podhalańska, 2017). The zonation was persistent long-term, though certain facies zones shifted in time 

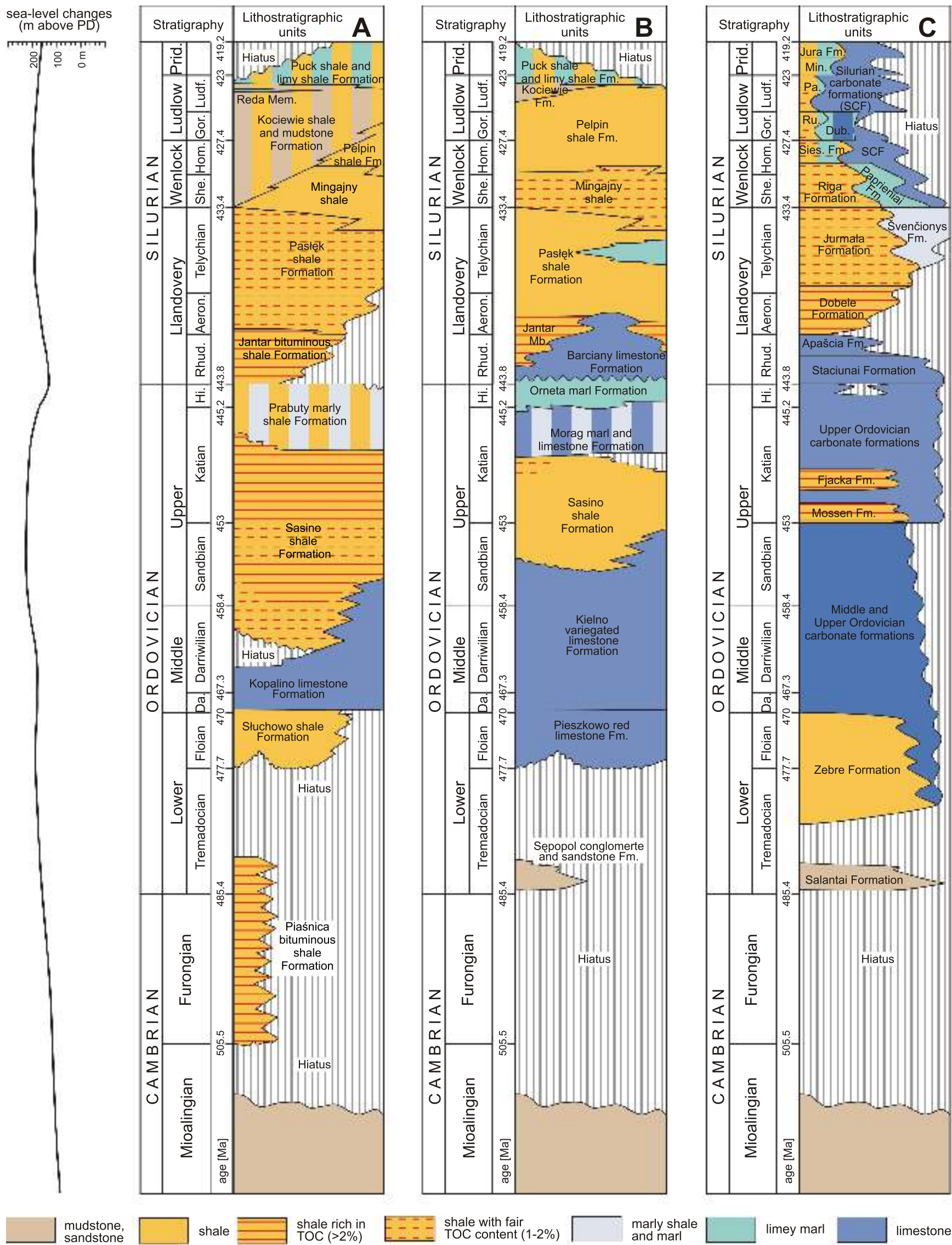

Fig. 9. Stratigraphic position of the main organic-rich shale formations within the stratigraphic section

A - central part of the Baltic Basin, B - eastern Baltic Basin (Poland), C - eastern Baltic Basin (Lithuania), D - Podlasie Depression, E (1997, 2005, 2008), Drygant et al. (2006), Szymański (2008), Dziadzio et al. (2017), and Porębski and Podhalańska (2017, 2019), modified Cichon-Pupienis et al. (2020). Eustatic sea level changes after Haq and Schutter (2008). Numerical ages after Cohen et al. (2013). Prid. $\mathrm{Da}$ - Dapingian. Abbreviations in C: Min. - Minija Fm., Pa. - Pagegiai Fm., Ru. - Rusnè Fm, Dub. - Dubysa Fm., Sies. - Siesartis Fm. 

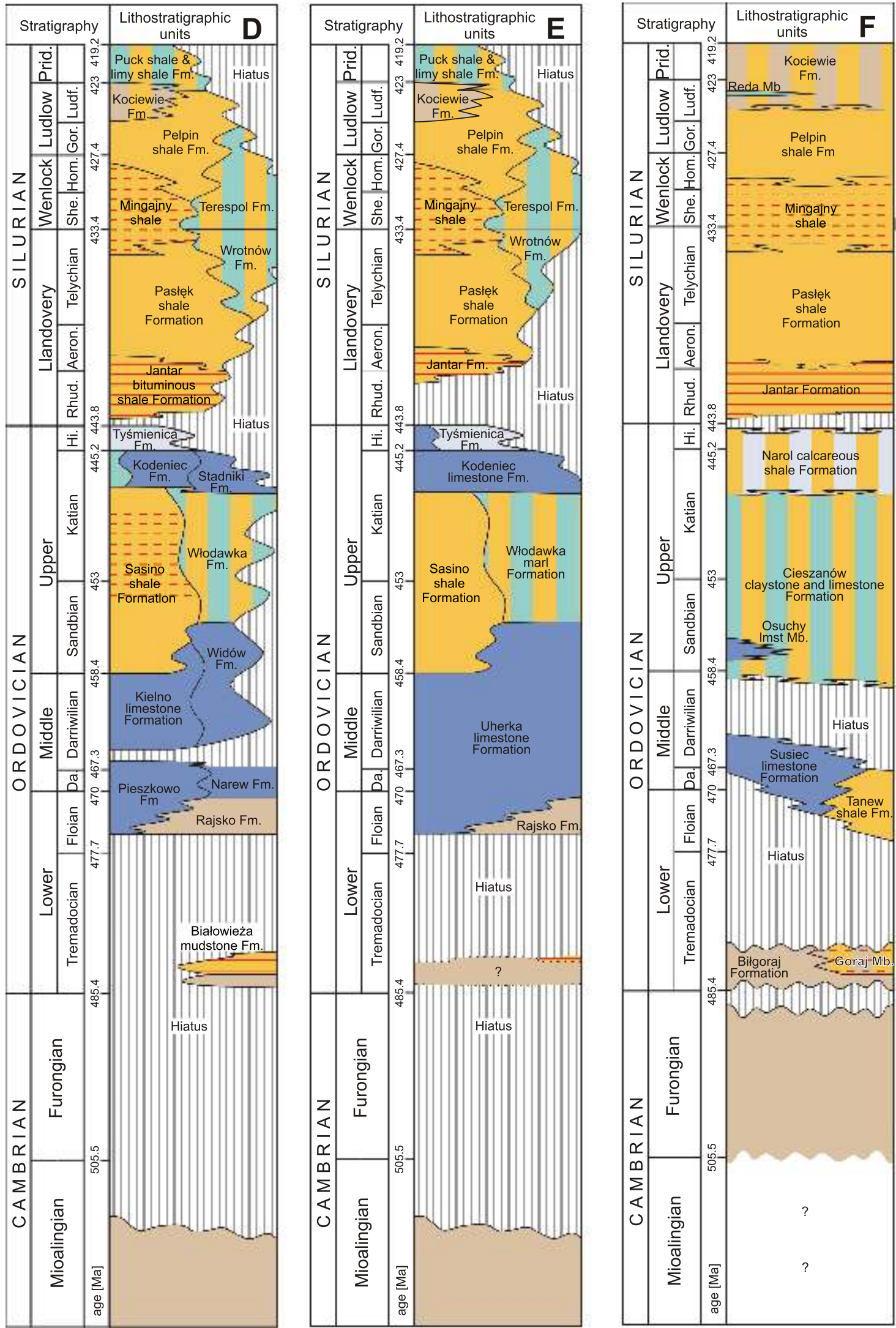

\section{of the lower Paleozoic on the western slope of the East European Craton}

Lublin Basin, F - Biłgoraj-Narol Zone. A and B - after Poprawa (2010a), modified. Based on Modliński et al. (2006), Modliński and Szymański and supplemented. C - based on data from Jacyna et al. (1997), Paškevičius (1997), Lazauskienè et al. (2003), Baltrūnas (2004), and Pridoli, Ludf. - Ludfordian, Gor. - Gorstian, Hom. - Homerian, She. - Sheinwoodian, Aeron. - Aeronian, Rhud. - Rhuddanian, Hi - Hirnantian, 


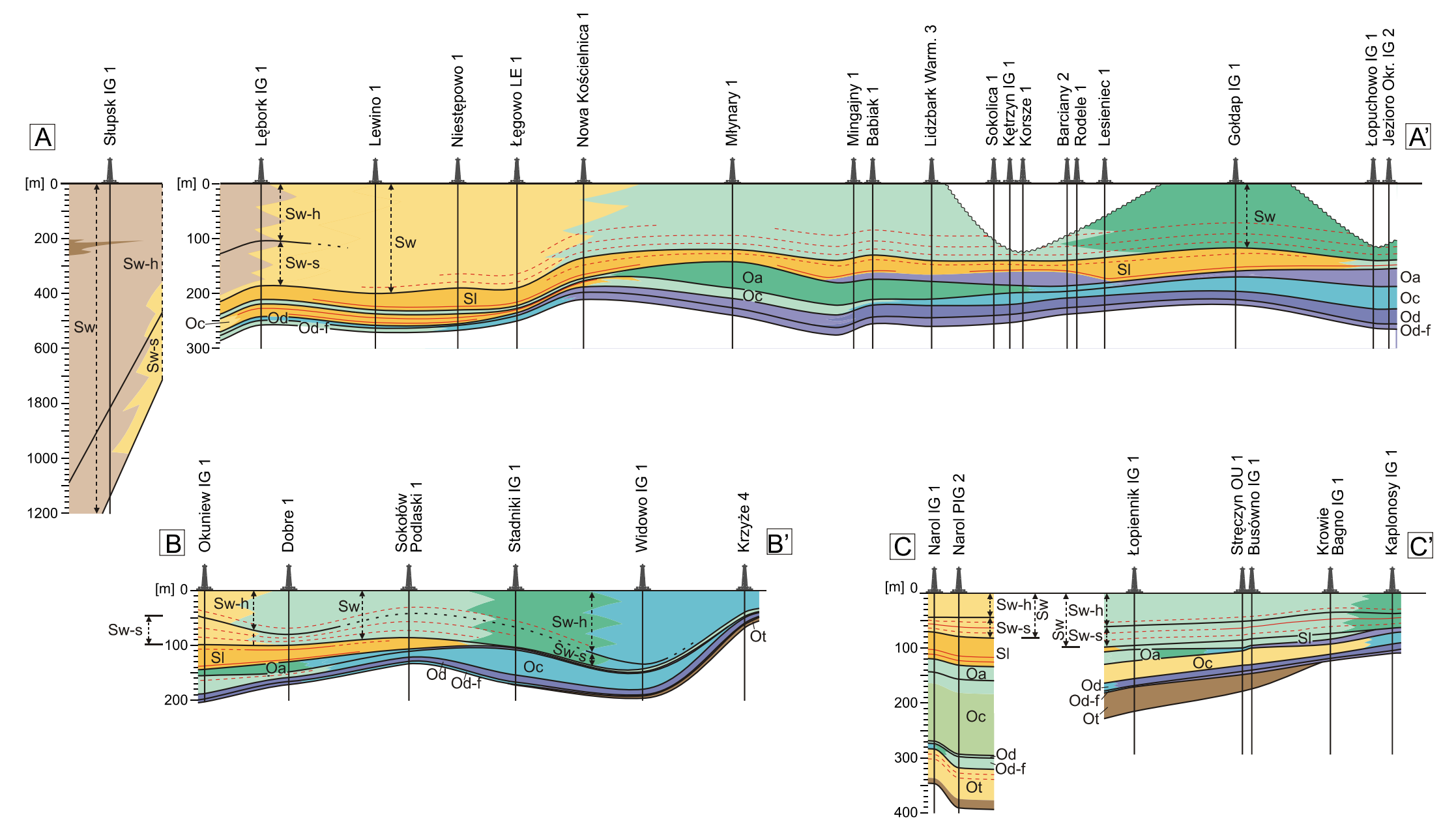
$20 \quad \underbrace{40 \quad \underbrace{60} \quad 80 \quad 100 \mathrm{~km} \quad 20 m m} \begin{gathered}\text { reginal unconfomity } \\ \text { erosional surface }\end{gathered}$

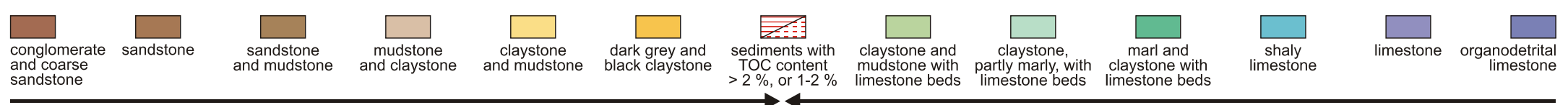

increasing average TOC content, decreasing oxygenation of the sea bottom

increasing average TOC content, increasing sea depth, decreasing oxygenation of the sea bottom

Fig. 10. Ordovician to lower Silurian lithofacies cross-sections though (A-A') the Baltic Basin, (B-B') the Podlasie Depression, and (C-C') the Lublin region

Note different vertical scale in the westernmost part of the cross-section A. After Poprawa (2019), modified and supplemented. B and C based on data of Modliński and Szymański (1997, 2005, 2008), Modliński at al. (2006, 2010), Drygant et al. (2006), Podhalańska (2017). Sw - Wenlock, Sw-h - Homerian, Sw-s - Sheinwoodian, $\mathrm{SI}$ - Llandovery, SI-r - Rhuddanian, SI-t - Telychian and Aeronian, Oa - Ashgill, Oc - Caradoc, Od - Darriwilian (Llanvirn), Od-f - Dapingian-Floian (Arenig) 

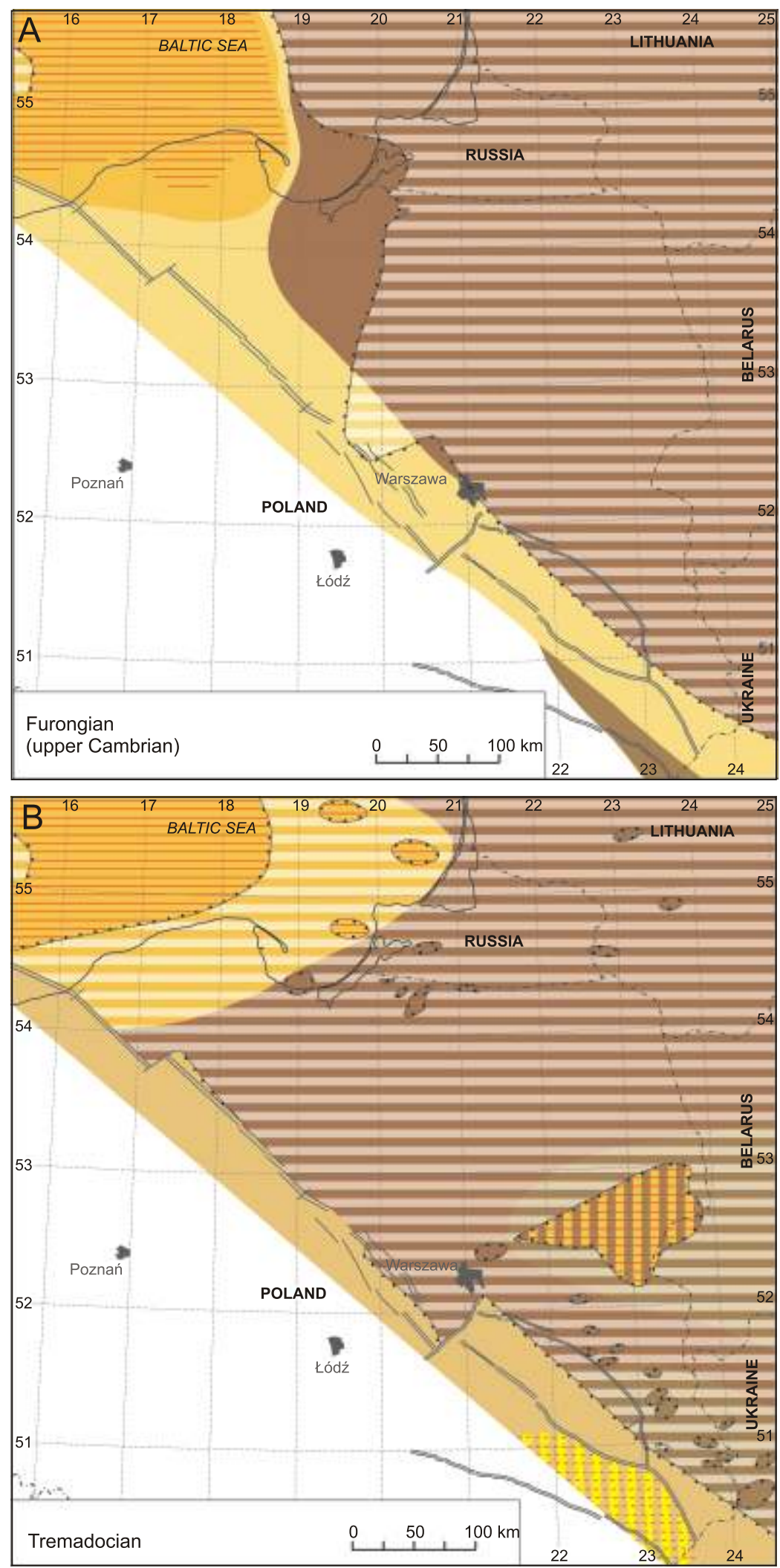

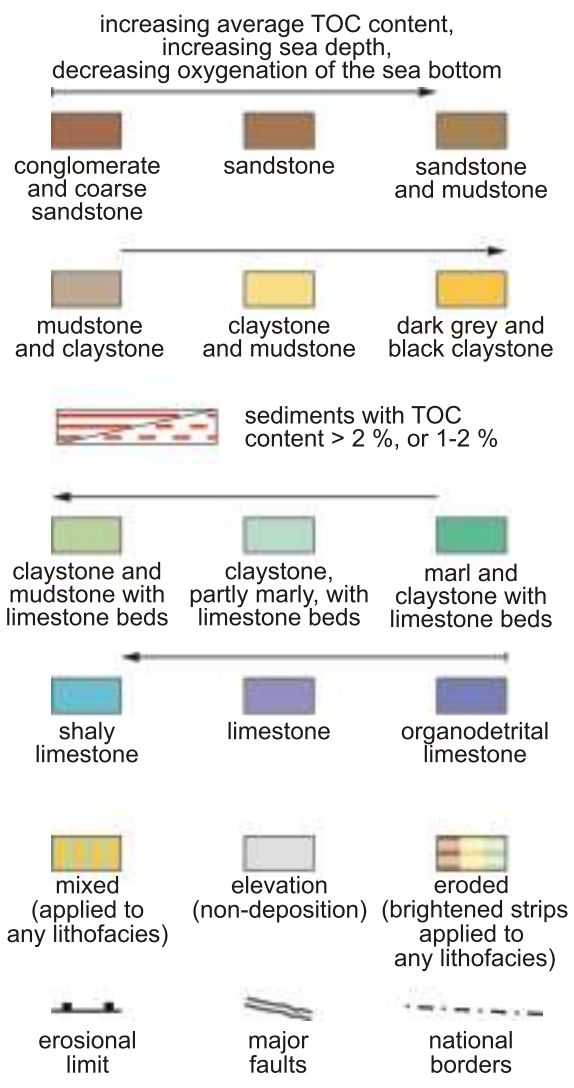

increasing average TOC content,
increasing sea depth, conglomerate
and coarse
sandstone $\quad \begin{gathered}\text { sandstone } \\ \text { and mudstone }\end{gathered}$

.



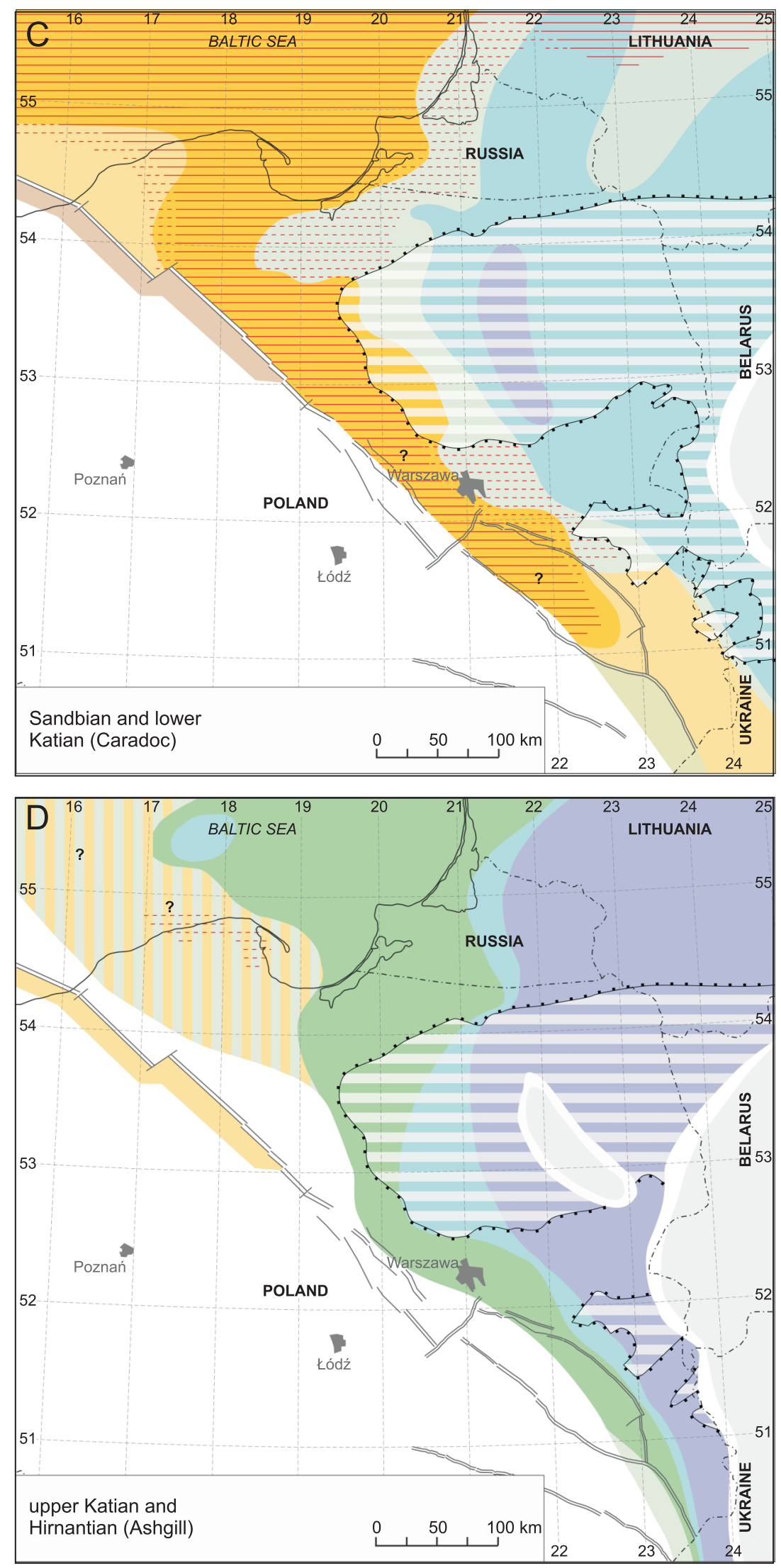

Fig. 11C, D

For explanations see Figure 11A, B 

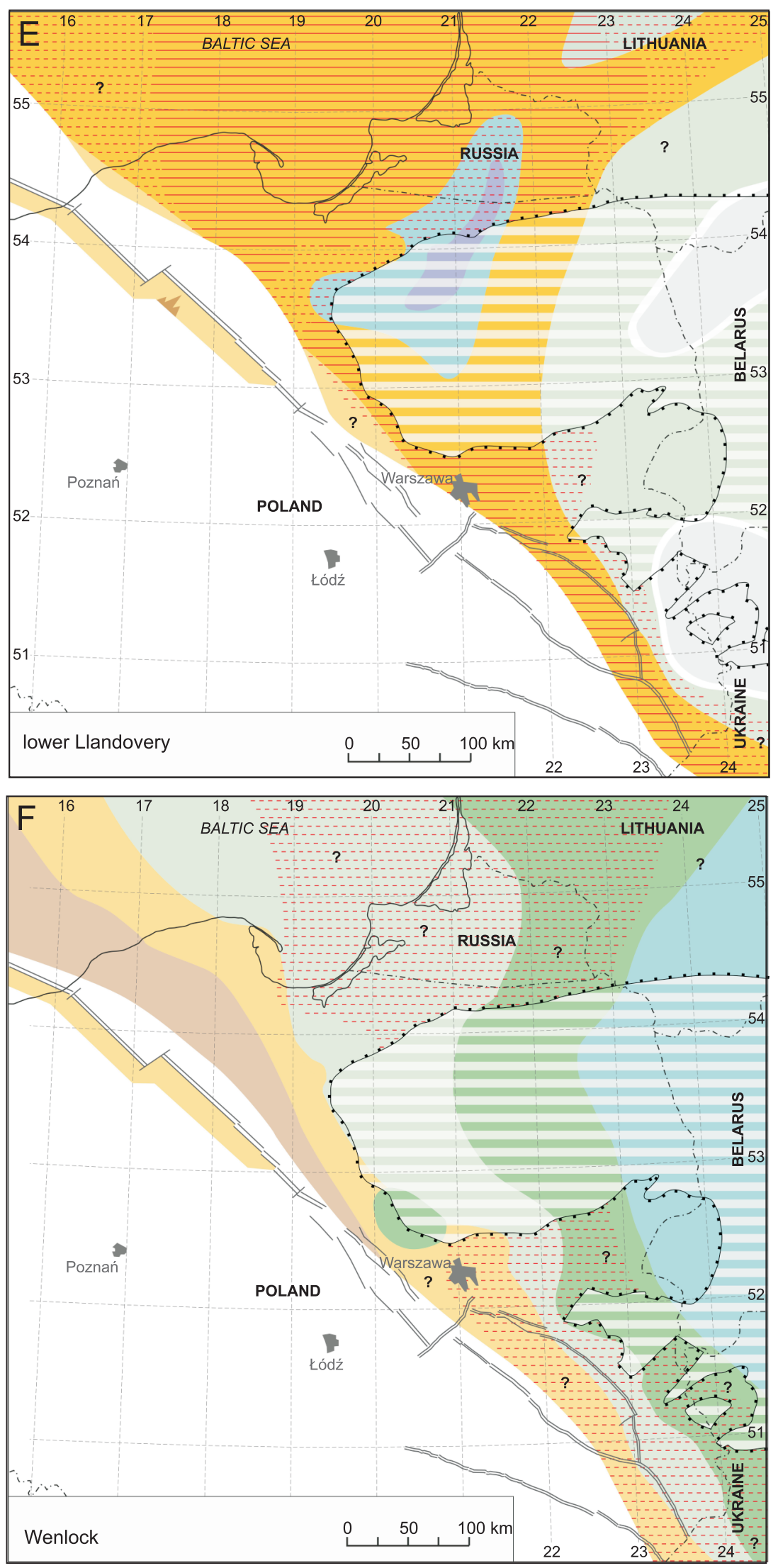

Fig. 11E, $F$

For explanations see Figure 11A, B 

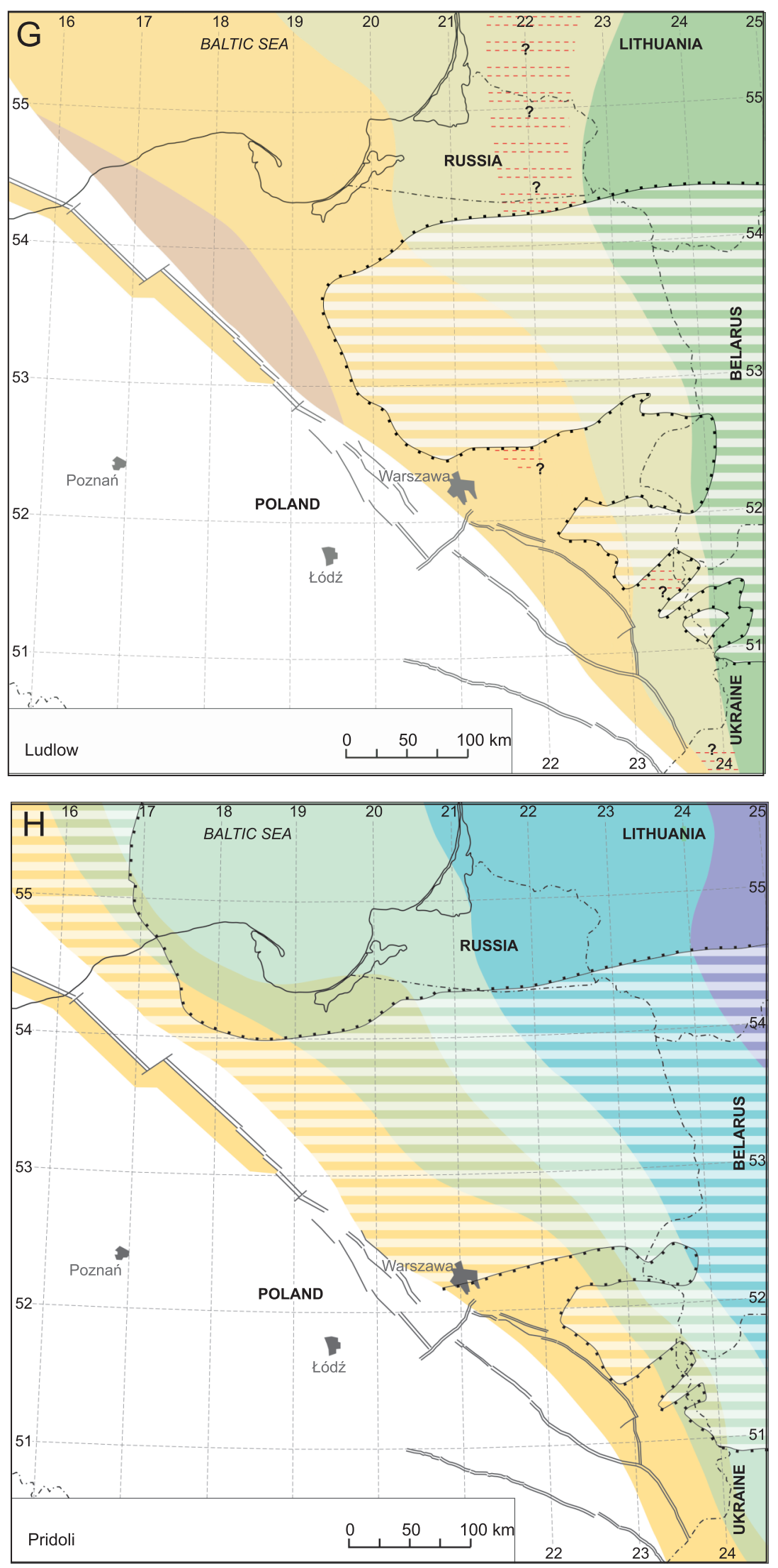

Fig. 11G, H

For explanations see Figure 11A, B 
Ordovic. Silur. Dev.
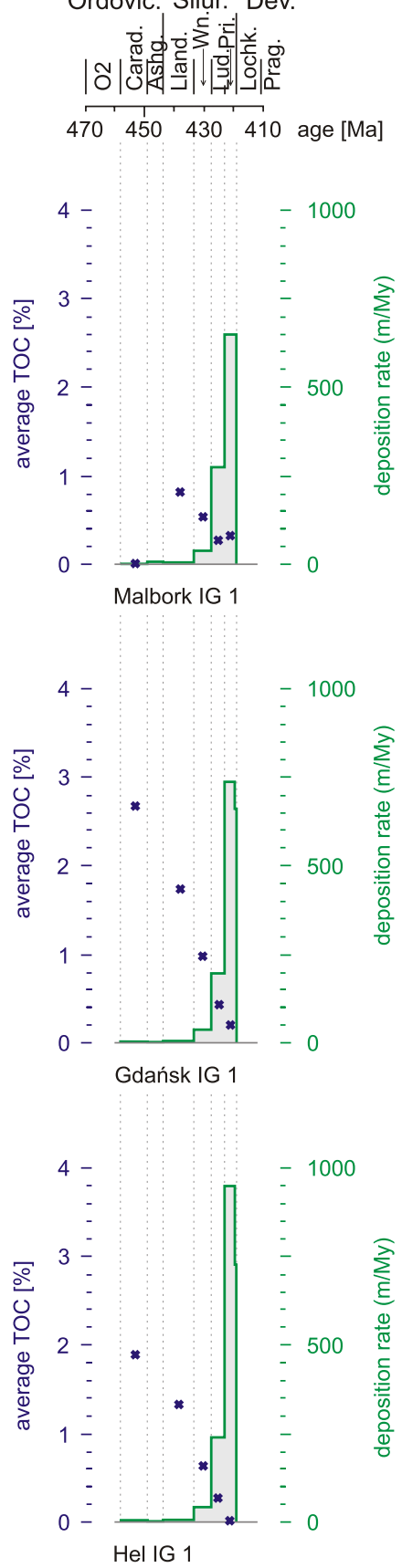

decompacted deposition rate

gross average TOC content of shale unit
Ordovic. Silur. Dev.
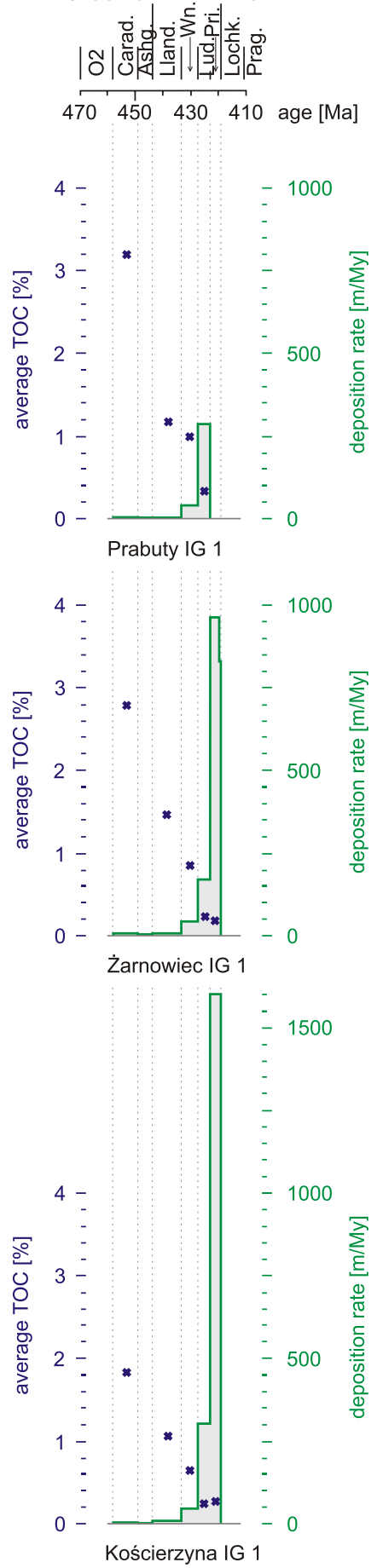

Fig. 12. Relation between the sediment depositional rate and the average total organic carbon content of the Upper Ordovician and Silurian shales

After Poprawa (2010a) modified

and the facies changed from limestone, partly organodetrital, occasionally with dolomite, through marls and marly shale, to dark grey or black shale (Figs. 10 and 11C-H). Average TOC content tends to increase westwards, according to the respective facies changes. Eventually, the zone of organic-rich dark grey or black shale deposition was limited to the west by rapid sedimentation of detritus derived from the Caledonian collision zone, resulting in the deposition of mudstone, siltstone and sandstone facies (Figs. 10 and $11 \mathrm{C}-\mathrm{H}$ ). That facies change was accompanied by a sharp westwards drop in the average TOC content.

During the earliest stage of the foredeep basin development, in the Caradoc (Sandbian and lower Katian), the zone of shale and mudstone deposition developed along the western margin of the Baltic-Podlasie-Lublin Basin (Fig. 11C), replacing previous Middle Ordovician carbonate deposition (Fig. 10; Modliński and Szymański, 1997; Paškevičius, 1997; Modliński et al., 2010). This facies transition resulted from a local increase in relative sea depth due to the start of basin flexure (Poprawa, 2006b), as well as from eustatic sea level rise (Fig. 9; Haq and Schutter, 2008). In the northwestern part of the area analysed, being more proximate to the tectonic load, i.e. in the central and northern parts of the Baltic Basin, the zone of shale deposition in the starved basin widened significantly towards the east during the Caradoc (Fig. 11C). This zone was characterized by the most favourable conditions for the development of organic-rich sediments. This is also due to the fact that there was hardly any detritus supply from the west to the basin at that time. The presence of organic-rich shale is characteristic of the Sasino Formation (Fig. 9A, D; Poprawa, 2010a; Porębski and Podhalańska, 2017). Towards the east, the shale deposition was replaced by organic-lean marl and marly limestone sedimentation (Figs. 10 and 11C; Modliński et al., 2010). However, to the north-east of the study area, in western Lithuania and southwestern Latvia, a carbonate-dominated Upper Ordovician section contains two organicrich shale formations of upper Caradocian (lower Katian) age; these are the Fjacka Formation and the Mossen Formation (Fig. 9C; Kanev et al., 1994; Zdanaviciute and Lazauskiene, 2007; Zdanavičiūtė and Lazauskiené, 2009; Cichon-Pupienis et al., 2020).

A decrease in eustatic sea level during Ashgill time, related to Gondwana glaciation (Fig. 9; Haq and Schutter, 2008), induced significant changes in the facies architecture of the Baltic-Podlasie-Lublin Basin (Poprawa et al., 1999; Podhalańska, 2009; Porębski et al., 2019). It caused a prominent shift of the carbonate facies towards the west, as well as restriction of the

towards the north-east or south-west, due to the balance between tectonic subsidence, detritus supply and eustatic sea level changes (Poprawa, 2019). Throughout the Late Ordovician and Silurian, the basin was rimmed to the east by a broad elevated zone, that was subject to erosion. Farther west and south-west, the marine basin became systematically deeper, shale deposition zone to the northwestern part of the Baltic Basin, the only zone where deposition of organic-rich sediments was preserved, and to lesser degree also to the Biłgoraj-Narol Zone (Figs. 10 and 11D; Modliński and Szymański, 1997; Modliński et al., 2010). The maximum sea level decrease, and maximum carbonate facies expansion in the basin, took place 
Characteristics of classic US shale reservoirs versus characteristics of the lower Paleozoic shale in the Baltic-Podlasie-Lublin Basin and the Biłgoraj-Narol Zone

\begin{tabular}{|c|c|c|}
\hline Gas shale parameter & US shale range & Polish shale range \\
\hline TOC content & $>2-10 \%$ & $1.5-5(10) \%$ \\
\hline Gamma ray API & $>150$ & $100-250$ \\
\hline Kerogen genetic type & II or I type & II type (mixed II/III) \\
\hline Hydrogen index (original HI) & $>250$ & $300-600$ \\
\hline Reservoir net thickness & $>15-20 \mathrm{~m}$ & $10-35(40) \mathrm{m}$ \\
\hline Gas-filled porosity & $>2-8 \%$ & $1.0-6 \%$ \\
\hline $\begin{array}{l}\text { Mineralogy - quartz and carbonate } \\
\text { contents }\end{array}$ & $>15-60 \%$ & variable, mostly moderate (up to $50 \%$ ) \\
\hline Mineralogy - clay contents & $<40(30) \%$ & variable, often $>30 \%$ \\
\hline \multirow{2}{*}{ Reservoir pressure } & \multirow{2}{*}{$\begin{array}{l}\text { pressure gradient } 1.0-1.56 \\
(0.45-0.7 \mathrm{psi} / \mathrm{ft})\end{array}$} & pressure gradient mostly $1.0(\sim 0.45 \mathrm{psi} / \mathrm{ft})$, \\
\hline & & locally $1.16-1.34(0.52-0.6 \mathrm{psi} / \mathrm{ft})$ \\
\hline Depth & $1000-3000 \mathrm{~m} \mathrm{(5000} \mathrm{m)}$ & $1500-5000 \mathrm{~m}$ \\
\hline Gas saturation contents & $2-10 \mathrm{~m}^{3} /$ ton & $1.5(2.0) \mathrm{m}^{3} /$ ton in the condensate window \\
\hline Matrix permeability & $>150 \mathrm{nD}$ & $\sim 100-200 \mathrm{nD}$ or less (300 max) \\
\hline \multirow{3}{*}{ Thermal maturity } & oil $-0.6-1.1 \%$ Ro & \multirow{3}{*}{$\begin{array}{c}\text { mostly favourable } \\
\text { (dominance of oil and liquids window) }\end{array}$} \\
\hline & liquids $-1.1-1.4 \%$ Ro & \\
\hline & dry gas $-1.4-3.0 \%$ Ro & \\
\hline Degree of tectonic deformation & $\begin{array}{c}\text { low; presence } \\
\text { of natural fracture systems }\end{array}$ & $\begin{array}{l}\text { mostly low (Baltic Basin), locally high } \\
\text { (Lublin region and Biłgoraj-Narol Zone) }\end{array}$ \\
\hline Uplift and erosion & $>1000 \mathrm{~m} ;<2000-3000 \mathrm{~m}$ & $500-2500 \mathrm{~m}$ \\
\hline Timing of gas/oil generation & young & $\begin{array}{c}\text { young (Mesozoic), or old (Variscan), } \\
\text { depending on location }\end{array}$ \\
\hline $\begin{array}{l}\text { Contents of non } \mathrm{HC} \text { gas components: } \\
\mathrm{H}_{2} \mathrm{~S} ; \mathrm{N}_{2}, \mathrm{CO}_{2}\end{array}$ & low & 等 \\
\hline
\end{tabular}

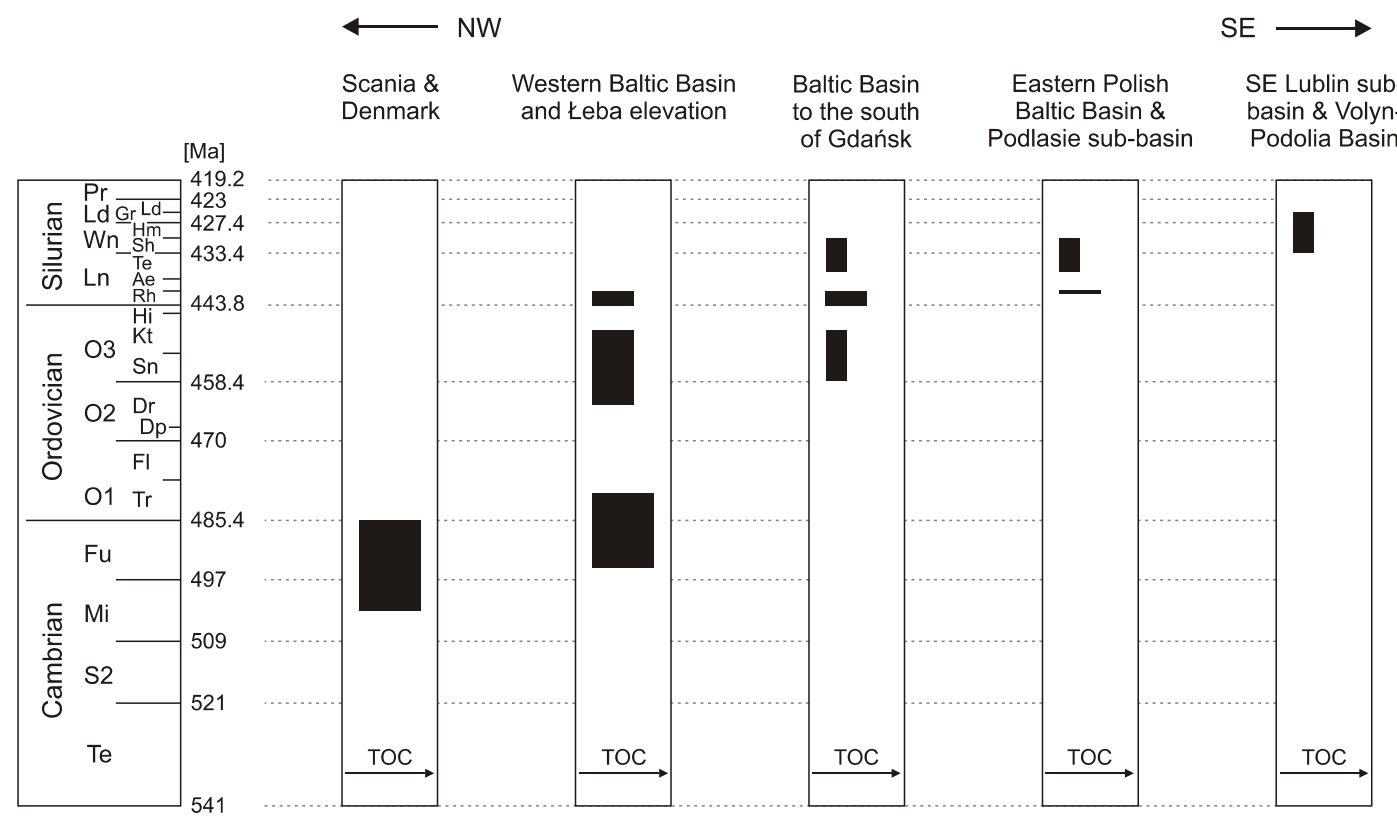

Fig. 13. Diachronism of organic-rich shale deposition on the western slope of the East European Craton

After Poprawa (2010a), modified and supplemented; compare Kiersnowski and Dyrka (2013)

during the Hirnantian (Podhalańska, 2009; Porębski et al., 2019).

Post-glacial global sea level rise during the early Llandovery (Fig. 9; Haq and Schutter, 2008) reconfigured facies zonation in the basin again, and the zone of shale deposition expanded eastwards significantly (Figs. 10 and 11E; Modliński et al., 2010). This was most prominent in the Baltic Basin, while towards the south-east lateral scale of expansion decreas (Fig. $11 \mathrm{E})$. Due to this, organic-rich shales of that age were deposited mainly in the Baltic Basin and the western Podlasie Depres- 
sion, and to a lesser degree also in the northwestern part of the Lublin region (Klimuszko, 2002). The highest TOC content is observed within the lower part of the Llandovery section (Poprawa, 2010a), equivalent to the Rhuddanian, represented by the Jantar Formation (Figs. 8 and 9; Porębski and Podhalańska, 2017). The Jantar Formation was deposited in a late stage of the starved foredeep basin development. In the eastern part of the Baltic Basin, in the lowermost part of the Llandovery section, the bituminous shale is locally replaced by dark nodular limestone of the Barciany Formation (Fig. 9B). This sedimentation developed on a sea floor elevation, which might be interpreted in terms of a fore-bulge, located in a distal part of the foreland of Caledonian orogen (Fig. 11E). Its axis being oblique to the western margin of the basin might reflect the oblique nature of the collision. Similar replacement of carbonate deposition by organic-rich shale occurred later in time, i.e. during the Aeronian, in western Lithuania and southwestern Latvia, where the Dobele Formation developed (Fig. 9C; Kanev et al., 1994; Zdanaviciute and Lazauskiene, 2007; Zdanavičiūtè and Lazauskienè, 2009; Cichon-Pupienis et al., 2020). Farther south-east in the Baltic Basin, the lower part of the Llandovery is represented by a systematically broader hiatus, and in the southern part of the Lublin region, as well as in the VolynPodolia-Moldova Basin, the Llandovery is missing (Radkovets, 2015; Podhalańska, 2017; Poprawa et al., 2018a).

Since the Wenlock, the supply of detritus from the Caledonian collision zone to the basin increased significantly, particularly in the western part of the Baltic Basin (Figs. 10A and 11F). This caused a decrease in the average TOC content within the diachronously deposited Kociewie Formation (Fig. 9). Progressive flexure of the basement created significant accommodation space, the proximal zone being, however, filled with mudstone, and occasionally with sandstone intercalations, due to tectonic uplift and intense erosion of the sediment source area (Figs. 10A and 11F). As a result of this, the Wenlock deposits in that zone have also very thick. Towards the east and south-east of the western Baltic Basin, the Wenlock strata pass into shaley and marly facies (Figs. 10A and 11F), characterized by slightly elevated TOC contents. This is particularly true for the eastern Baltic Basin (Fig. 9B), the western Podlasie Depression (Fig. 9D), the Lublin region (Fig. 9E), and the Biłgoraj-Narol Zone (Fig. 9F). The Wenlock shale enriched in TOC was deposited also farther south-east, in the northern part of the VolynPodolia-Moldova Basin (Gautier et al., 2012; Sachsenhofer and Koltun, 2012). Elevated TOC contents, ranging between 1.4 and $1.7 \mathrm{wt} . \%$ (with $2.0 \mathrm{wt} . \%$ at maximum), are typical of the lower Wenlock (sometimes also of the top part of Llandovery), here referred to as the informal Mingajny shale (Fig. 9). The name refers to the Mingajny 1 borehole, located in the eastern Baltic Basin (borehole 36 on Fig. 2), where the geochemical characteristics of this part of the Silurian section have been documented in detail.

A similar facies architecture characterizes the Ludlow section, although detritus supply to the basin from the west intensified at that time, and the Kociewie Formation mudstone facies prograded eastwards (Figs. 9 and $11 \mathrm{G}$ ). A high deposition rate resulted, with low average TOC contents of these sediments (Fig. 12). Tectonically-driven increase in accommodation space, and increased supply of detritus, resulted in a very large thickness of the Ludlow deposits, particularly in the western Baltic Basin (Fig. 8). A prominent thickness decrease in the Ludlow deposits towards the south-east is observed, associated with transition into a distal facies (Fig. 11G; Modliński et al., 2010).

During the Pridoli, the main depocentre of the BalticPodlasie-Lublin Basin shifted to the Lublin region (Modliński et al., 2010; Poprawa, 2019). In the Baltic Basin, marly shale dominated at that time, while in the Lublin region mudstone and claystone prevailed (Fig. $11 \mathrm{H})$. As in the case of the Ludlow, also during the Pridoli, a very high sediment depositional rate reduced the average TOC content of the fine-grained sediments (Fig. 12). Neither the Ludlow nor the Pridoli successions show any shale oil/gas exploration potential.

\section{CHARACTERISTICS OF THE LOWER PALEOZOIC OIL AND GAS SHALE}

Several years of intense exploration and production of shale gas and shale oil in USA and Canada, and to a lesser degree in the other parts of the world, has resulted in considerable practical experience and allowed definition of the characteristics required for a shale formation so it becomes an unconventional reservoir with commercial potential (Table 1; e.g., Gasparik et al., 2013; Kuuskraa et al., 2013; Zou et al., 2013; Hackley and Cardott, 2016). Among the key shale reservoir parameters is a high content of TOC, determining both the amount of hydrocarbons generated and the volume of secondary organic porosity, as well as affecting the possibility of developing high reservoir pressure (e.g., Pollastro et al., 2007; Passey et al., 2010; Whitelaw et al., 2019). Apart from TOC, the quality of shale source rock might be determined by its type of kerogen and original hydrogen index (Jarvie et al., 2007; Jarvie, 2012a, b; Hackley and Cardott, 2016). Thermal maturity defines the potential of shale to generate hydrocarbons, the type of hydrocarbons saturating the shale reservoir, and the risk of overmaturation (Hill et al., 2007; Bernard and Horsfield, 2014; Agrawal and Sharma, 2018). Increasing thermal maturity results also in a rise of secondary, organic porosity (Passey et al., 2010; Jarvie, 2012a, b; Hackley and Cardott, 2016). The net thickness of a shale productive interval determines the key constraints for commercial shale gas/oil production, such as the initial production, estimated ultimate recovery and oil and/or gas resources and reserves (EIA, 2011, 2013; Charpentier and Cook, 2013; Sandrea and Sandrea, 2014; Smith and Lee, 2017). As in the case of conventional fields, the composition of hydrocarbons remains one of the commercially important features of shale gas or oil accumulation. A high content of non-hydrocarbon components, such as nitrogen or carbon dioxide, might considerably lower the energetic and commercial value of the gas. The presence of hydrogen sulphide in gas or oil in considerable amounts might also be disadvantageous for the economic viability of a field's exploitation, since it might create environmental and health risk.

From the oil/gas production point of view, the petrophysical and mineralogical characteristics of a shale reservoir is of key importance (Table 1). The composition of the minerals forming a shale reservoir, in particular the content of brittle minerals such as quartz, carbonates and feldspar, and the content of ductile ones, mainly clay minerals, determines the effectiveness of hydraulic fracturing of a reservoir. Of similar importance are geomechanical parameters, i.e. the Poisson's ratio and Young's modulus (Sone and Zoback, 2013a, b; Gao et al., 2019; Zoback and Kohli, 2019).

Shale reservoirs differ from conventional reservoirs as their petrophysical characteristics (Passey et al., 2010; Bohacs et al., 2013; Song et al., 2016): the porosity of a shale reservoir is up to an order of magnitude lower, while permeability is lower by several orders of magnitude. Nonetheless, both parameters are important to the understanding of oil/gas resources and reserves, 
as well as to predict flow rates from production boreholes and production decline. Moreover, porosity defines the gas/oil saturation of a shale reservoir, being a fundamental characteristic of the shale hydrocarbon field, whereas permeability determines the recovery factor. The latter parameter in a shale reservoir may be as low as $1-10 \%$ for oil and $5-30 \%$ for gas, therefore, it significantly affects technically recoverable gas/oil resources (Tella, 2011; EIA, 2013; McGlade et al., 2013).

The porosity of a shale reservoir has a significant impact on its gas saturation. The latter is one of the most important parameters defining shale commercial potential, since it affects the scale of gas flow rate from a borehole, as well as gas ultimate recovery. The shale formations producing gas in the US typically have gas saturation at levels of $2-10 \mathrm{~m}^{3} /$ ton (Table 1 ).

Further aspects of shale oil/gas field characteristics are burial depth, burial history, degree of tectonic deformation, and reservoir pressure (Table 1). Recent burial depth remains an element of the shale gas/oil productive formation characteristics which greatly determines the commercial, and to a lesser degree also technological, ability to develop a prospect. The high dependence of borehole drilling and hydraulic fracturing costs on burial depth sets, within a given basin, a certain depth cut-off, limiting exploration activity (EIA, 2011, 2016; Smith and Lee, 2017). The exact maximum burial depth acceptable for shale gas/oil projects is hard to define prior to production, since higher production costs resulting from deep reservoir burial might be compensated by a high hydrocarbon flow rate and a high borehole ultimate recovery. This is, however, a constraint available for basins with ongoing shale oil/gas production. Nonetheless, the USA experiences indicate that recent burial depth of shale reservoir in the range of $3500-4500 \mathrm{~m}$ is a cost limit for current-stage technology (e.g., EIA, 2011, 2016; Bohacs et al., 2013; Anthonsen et al., 2016).

The burial and thermal history allows us to define the timing of oil and gas generation (e.g., Tissot and Welte, 1984; Dembicki, 2017). Moreover, it impacts reservoir pressure, since hydrocarbon generation early in basin history often results in subsequent partial depletion of gas or oil. The same effect is related to large-scale exhumation and denudation. The practical observation in USA shale basins is that with uplift greater than (2 000?-)3 $000 \mathrm{~m}$ overpressures are not preserved (Cander, 2013). Tectonic deformation is another factor which impacts the commercial potential of a shale basin. The higher the tectonic deformation, the more difficult it is to navigate a deviated or lateral section of a borehole, and the less effective is hydraulic fracturing. Moreover, intense tectonic deformation raises a risk of hydrocarbon release from the shale reservoir. The latter risk is equally related to magmatic activity in the basin (Pool et al., 2012; De Kock et al., 2017). However, the existence of a dense, penetrative system of natural fractures, e.g. a joint system, considerably increases the effective permeability of the rock matrix, feeding gas into hydraulic fractures and, therefore, to the borehole (Gale and Holder, 2010; Gale et al., 2014; Patzek et al., 2014).

Due to new data from the shale gas/oil exploration, and to lesser degree also legacy data, all the above criteria could currently be applied to define characteristics of the lower Paleozoic shale in the Baltic-Podlasie-Lublin Basin (Table 1 and Fig. 14).

\section{CHARACTERISTICS OF ORGANIC MATTER}

Having in mind that the TOC content cut-off, which distinguishes the shale with and without unconventional oil/gas potential, is usually set either at 2 or at $1.5 \mathrm{wt} . \%$, and that a prolific shale formation might have an average TOC content up to 10 wt.\% or more, the lower Paleozoic shale in the Baltic-Podlasie-Lublin Basin could be generally considered as of mostly moderate to low quality, and locally of good quality. The TOC content varies considerably, both laterally and in stratigraphically. In general, the highest average TOC is observed in the central Baltic Basin, where it reaches on average roughly 3-5 wt.\% (Fig. 14 comp. Karcz and Janas, 2016). Towards the east and the south the average TOC content decreases, and in the eastern part of the Baltic Basin, as well as in the Lublin region, it generally falls below 2 wt.\% (Fig. 14), becoming there one of the key exploration risk factors.

Very high average TOC content characterizes the upper Cambrian to Tremadocian Piaśnica Formation, equivalent to the Alum shale (Fig. 9A). It can be as high as 5 to $12 \mathrm{wt} . \%$, and, due to coeval high RockEval S1+S2, the shale might be often qualified as a good, very good or excellent source rock (Fig. 15A). Lower source rock quality of the Piaśnica Formation is related to the southern limits of its lateral extent, as well as to the western offshore Baltic Basin, where the shale has high thermal maturity. The lower Tremadocian shale in the Podlasie Basin (Białowie a Formation) is also classified as a very good to an excellent potential source rock (Figs. 9A and 15A). The presence of organic-rich shale of upper Cambrian to Tremadocian age is limited to the western offshore Baltic Basin, the northern part of the central onshore Baltic Basin in Poland (northern Łeba Elevation), and to the eastern part of the Podlasie Depression (Fig. 11A, B). The Piaśnica and Białowie a formations are characterized by the type II kerogen, favourable for the development of shale gas and oil accumulations (Figs. 16A and 17A).

The next organic-rich shale formation up-section, the Sasino Formation (Fig. 9), is characterized by laterally highly variable source rock quality characteristics. It is developed across a large area, covering the Baltic Basin, except for its southwestern and southeastern part, the western Podlasie Depression, and the northwestern Lublin region (Fig. 11C). It extends also into the western Kaliningrad region and into western Lithuania (Fig. 11C), where it is limited, however, to the upper Caradoc (lower Katian; Fig. 9C; Zdanavičiūtè and Bojesen-Koefoed, 1997; Zdanavičiūtè et al., 1998; Lazauskienè et al., 2003; Cichon-Pupienis et al., 2020). In the central and western Baltic Basin it is usually a good to fair source rock, while in the eastern Baltic Basin, the central and eastern Podlasie Depression, and across most of the Lublin region, it is a poor source rock (Fig. 15A). The uppermost Ordovician Prabuty marl, overlying the Sasino Formation (Fig. 9), has no source rock potential (Fig. 15A). In the kerogen type discrimination diagram, illustrating the Rock-Eval hydrogen index $(\mathrm{HI})$ versus oxygen index (OI), both the Sasino and the Prabuty marl reveals characteristics of the mixed II and III type of kerogen (Fig. 16A). However, in the kerogen type discrimination diagram, illustrating the Rock-Eval hydrogen index $(\mathrm{HI})$ versus Tmax temperature, data for both the formations indicate a dominance of type II kerogen (Fig. 17A).

The lower Llandovery, mainly Rhuddanian, Jantar shale Formation and its equivalents (Fig. 9; Porębski and Podhalańska, 2019) has a higher lateral extent than other organic-rich shale formations in the Baltic-Podlasie-Lublin Basin (Fig. 11E). It is very broadly developed across the Baltic Basin, including its Polish, Russian, Lithuanian and Latvian parts (Kanev et al., 1994; Zdanavičiūtè and Swadowska, 2002; Modliński et al., 2006; Skręt and Fabiańska, 2009; Filar et al., 2015; Cichon-Pupienis et al., 2020). However, in the eastern part of the Baltic Basin, it is mainly of upper Rhuddanian (Fig. 9B) or Aeronian age (Fig. 9C - Dobele Formation). Towards the 

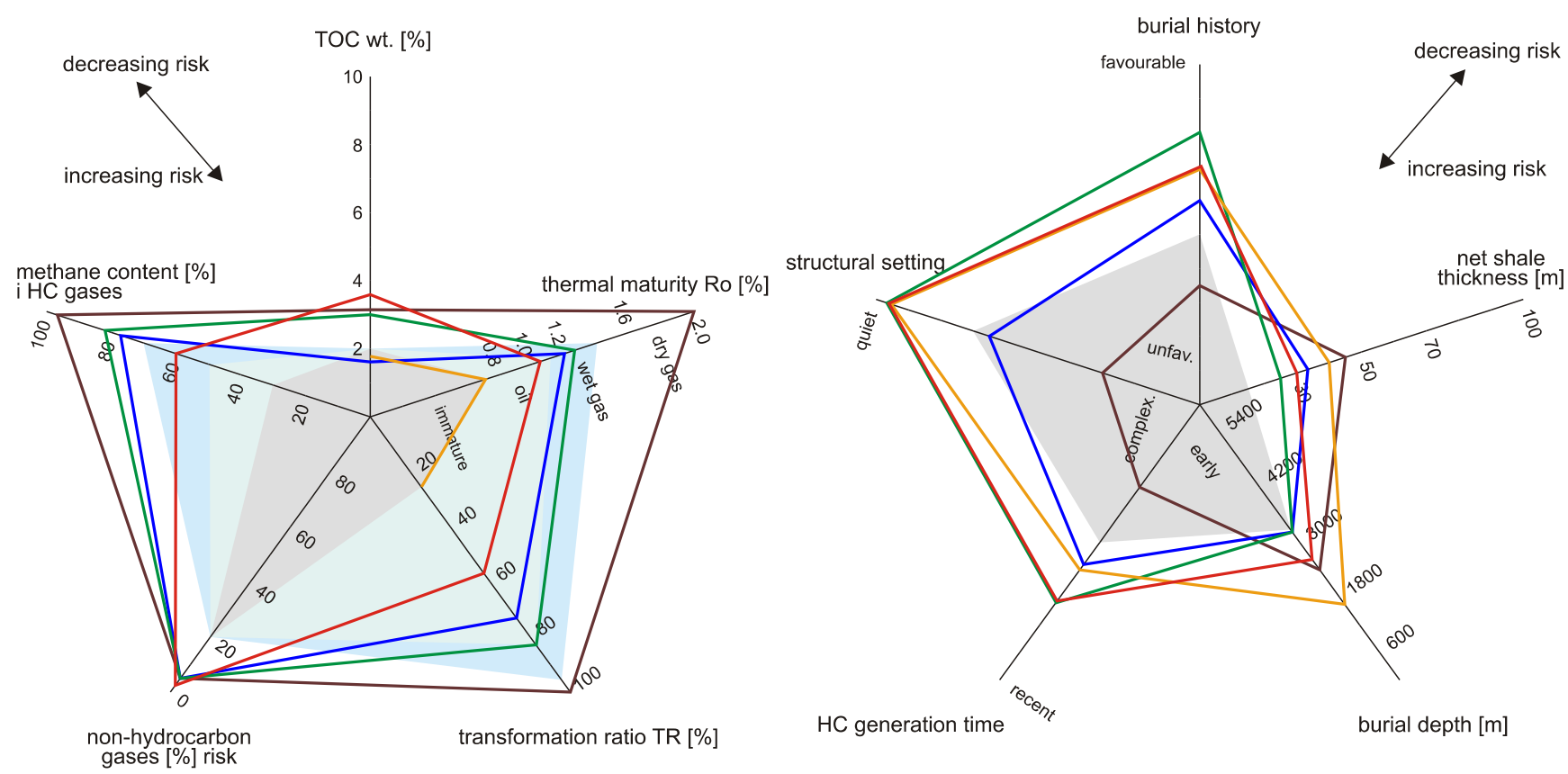

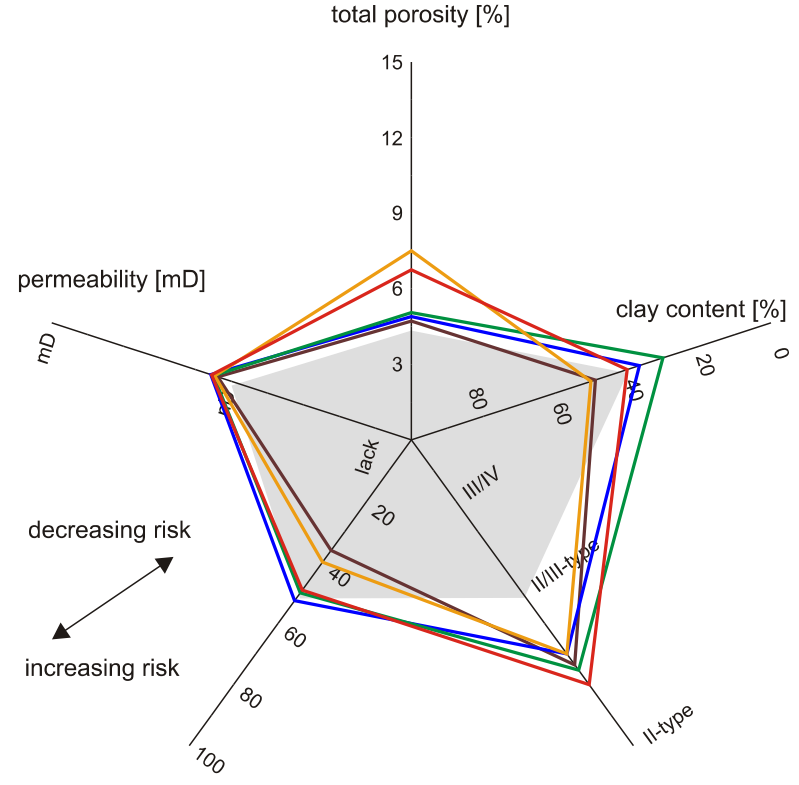

silica \& carbonate content $[\%]$ kerogen type

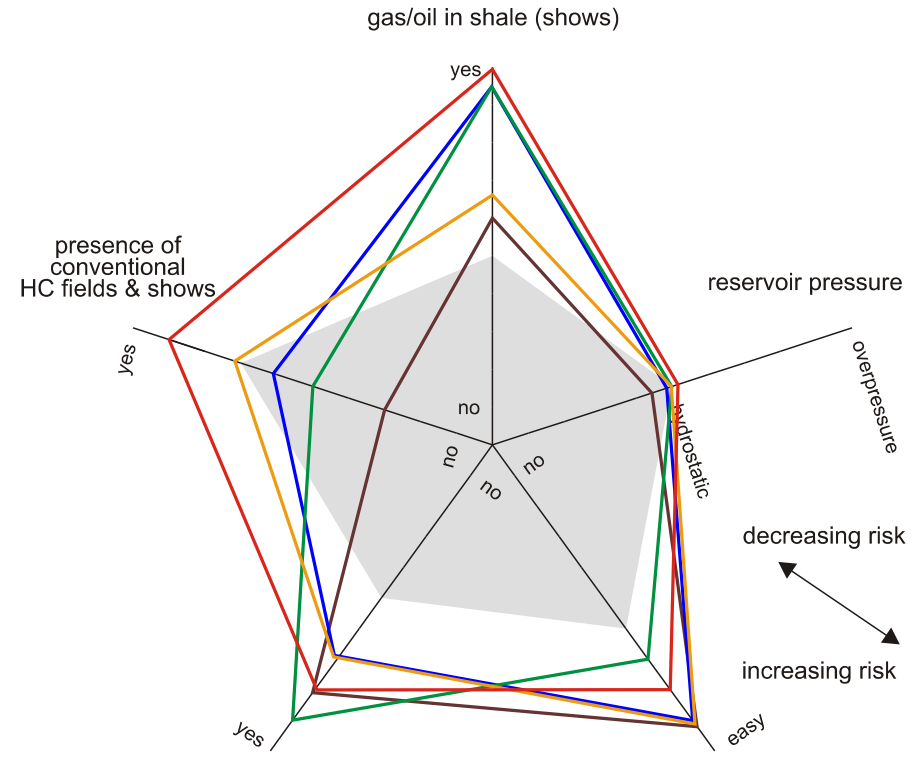

presence of infrastructure

surface access

\begin{tabular}{l|l|l|l}
1 & 2 & 3 & values within high risk zone
\end{tabular}

for (1) oil, (2) condensate, (3) gas

values within high risk zone

Values typically observed in the given part of the basin:

A -central Baltic Basin (Łeba Elevation)
B - eastern Polish Baltic Basin
C - western Podlasie Depression
D -western Lublin region
E - Biłgoraj-Narol

\section{Fig. 14. Geological and geochemical shale gas exploration risk assessment}

Spider diagrams for the Sasino and Jantar shale in the central Baltic Basin (A), the Mingajny shale in the eastern Baltic Basin (B), the Jantar and Mingajny shale in the western Podlasie Depression (C), the Mingajny shale in the central part of the Lublin region (D), and the Jantar and Mingajny shale in the Biłgoraj-Narol Zone (E). Compare Poprawa (2010), Poprawa and Kiersnowski (2008), Kiersnowski and Dyrka (2013) 

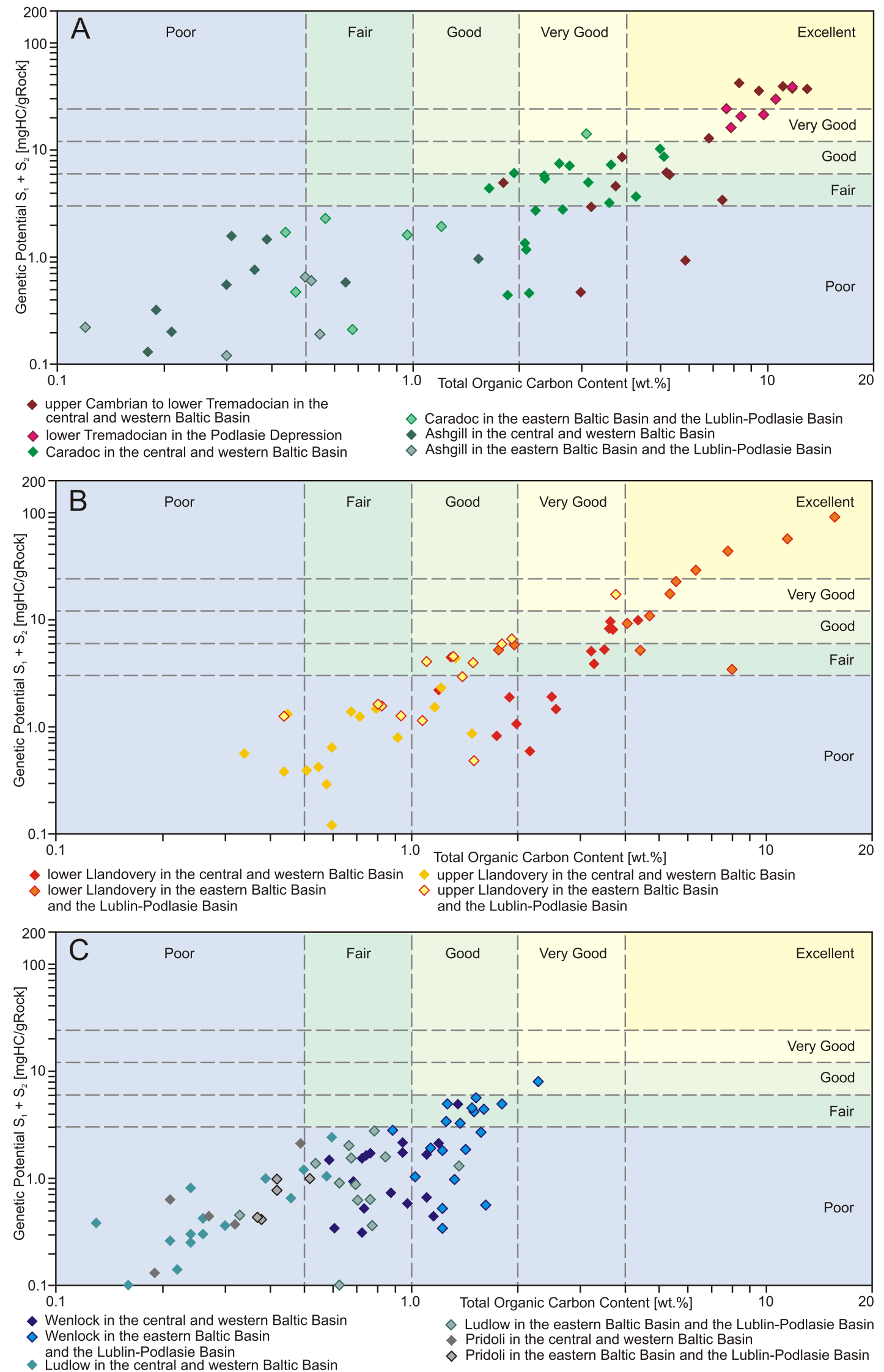

Fig. 15. Source rock quality diagram for the lower Paleozoic organic matter

A - upper Cambrian and Ordovician shale, B - Llandovery shale, C - Wenlock, Ludlow and Prodoli shale; classification after Peters and Cassa (2002); each data point represents an average value in an individual borehole 


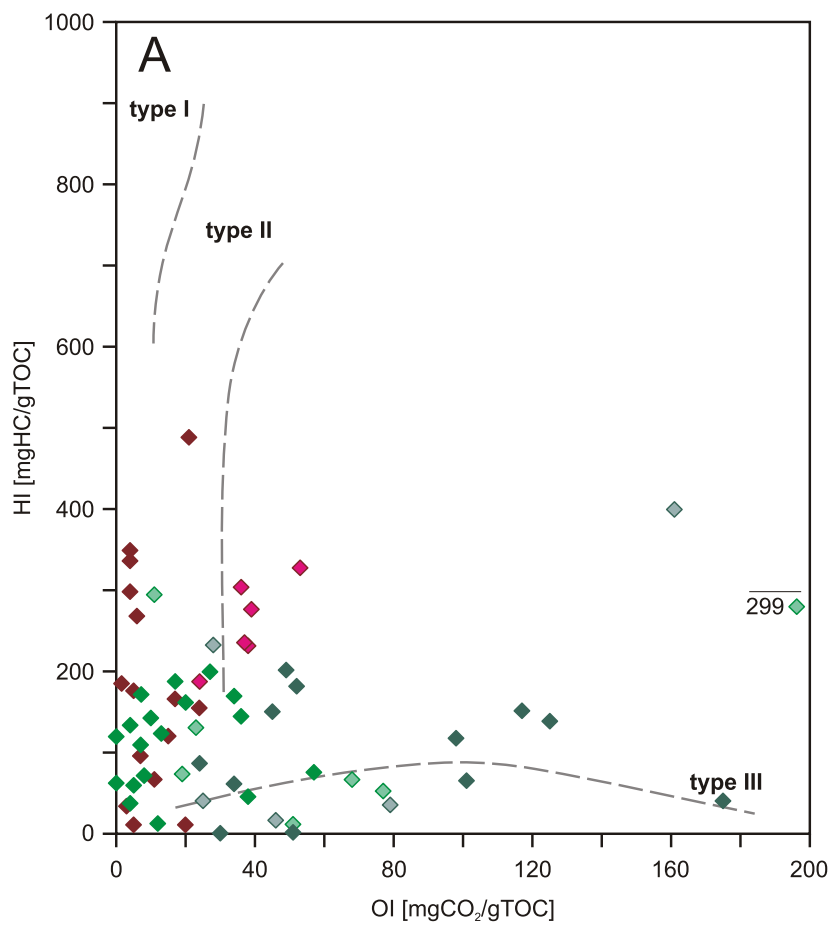

- upper Cambrian to lower Tremadocian in the central and western Baltic Basin - lower Tremadocian in the Podlasie Depression

- Caradoc in the central and western Baltic Basin

$\diamond$ Caradoc in the eastern Baltic Basin and the Lublin-Podlasie Basin

Ashgill in the central and western Baltic Basin

$\diamond$ Ashgill in the eastern Baltic Basin and the Lublin-Podlasie Basin

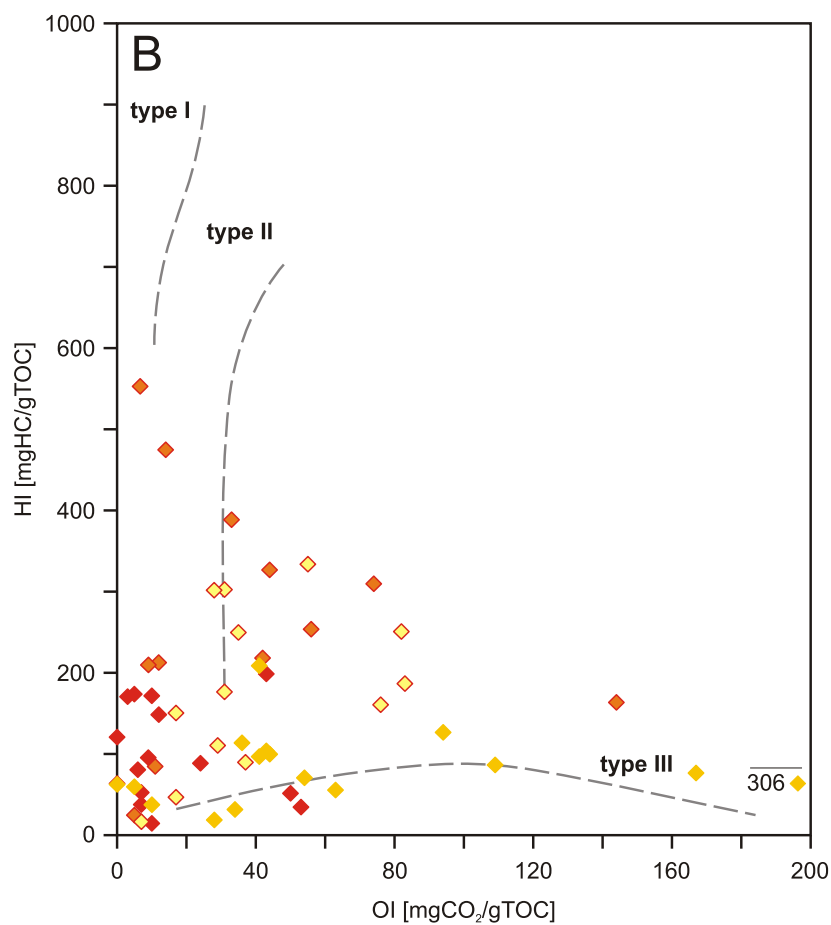

- lower Llandovery in the central and western Baltic Basin

$\diamond$ lower Llandovery in the eastern Baltic Basin and the Lublin-Podlasie Basin

upper Llandovery in the central and western Baltic Basin

$\diamond$ upper Llandovery in the eastern Baltic Basin and the Lublin-Podlasie Basin

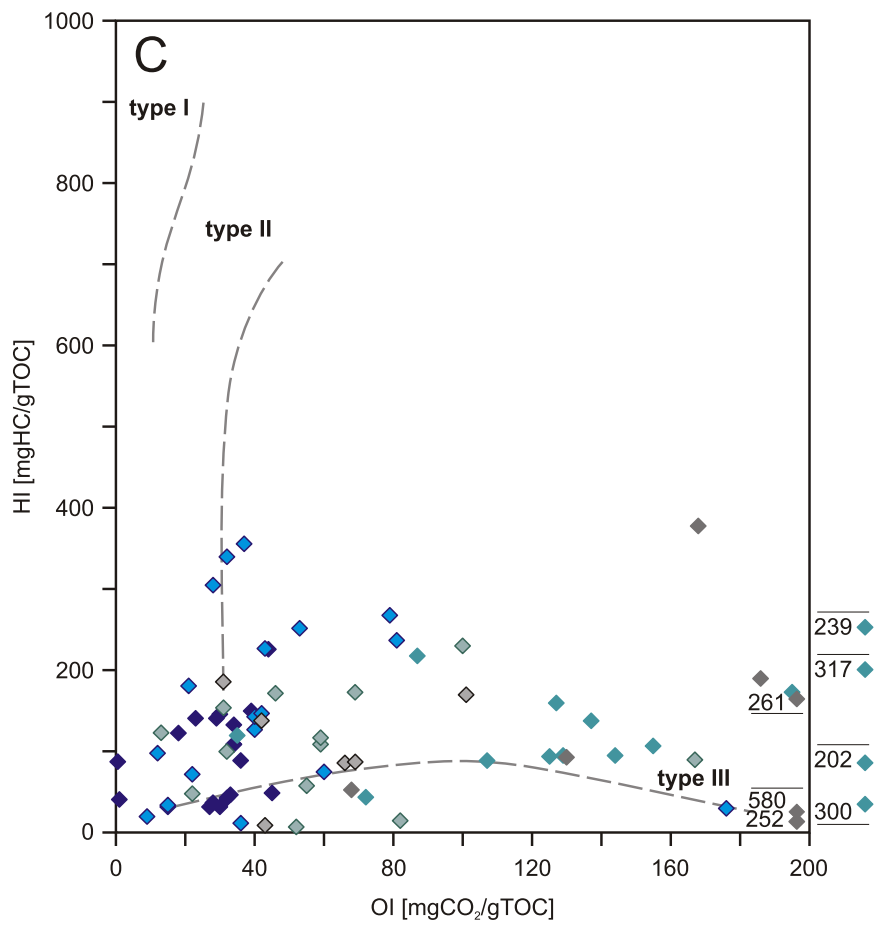

- Wenlock in the central and western Baltic Basin

$\diamond$ Wenlock in the eastern Baltic Basin and the Lublin-Podlasie Basin

Ludlow in the central and western Baltic Basin

$\checkmark$ Ludlow in the eastern Baltic Basin and the Lublin-Podlasie Basin

- Pridoli in the central and western Baltic Basin

$\diamond$ Pridoli in the eastern Baltic Basin and the Lublin-Podlasie Basin

Fig. 16. Prevailing kerogen type based on the Rock-Eval hydrogen index $(\mathrm{HI})$ versus oxygen index (OI)

A - upper Cambrian and Ordovician shale, B - Llandovery shale,

C - Wenlock, Ludlow and Prodoli shale; each data point represents an average value in an individual borehole 


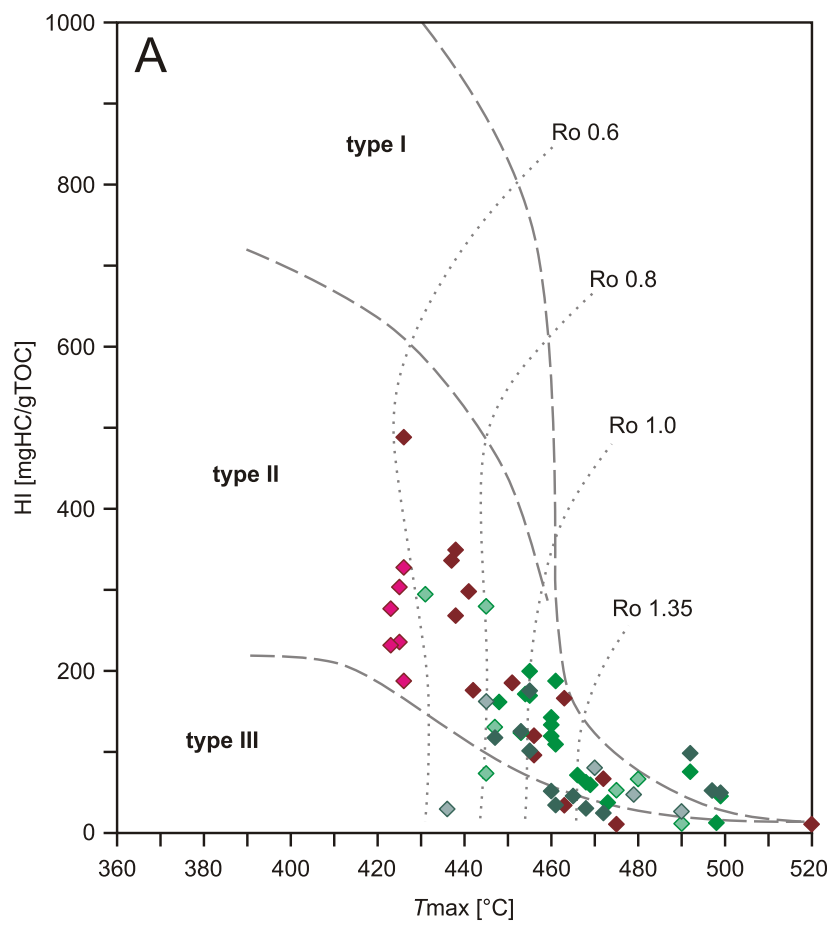

- upper Cambrian to lower Tremadocian in the central and western Baltic Basin - lower Tremadocian in the Podlasie Depression

Caradoc in the central and western Baltic Basin

$\diamond$ Caradoc in the eastern Baltic Basin and the Lublin-Podlasie Basin

- Ashgill in the central and western Baltic Basin

$\diamond$ Ashgill in the eastern Baltic Basin and the Lublin-Podlasie Basin

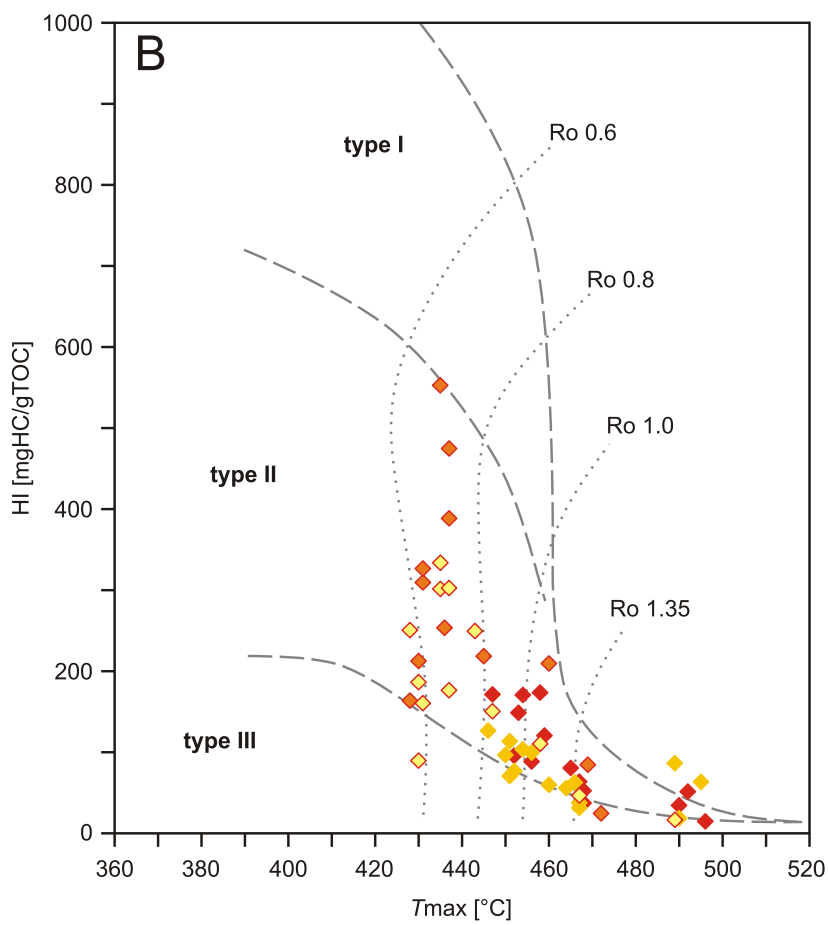

- lower Llandovery in the central and western Baltic Basin

$\diamond$ lower Llandovery in the eastern Baltic Basin and the Lublin-Podlasie Basin

upper Llandovery in the central and western Baltic Basin

$\diamond$ upper Llandovery in the eastern Baltic Basin and the Lublin-Podlasie Basin

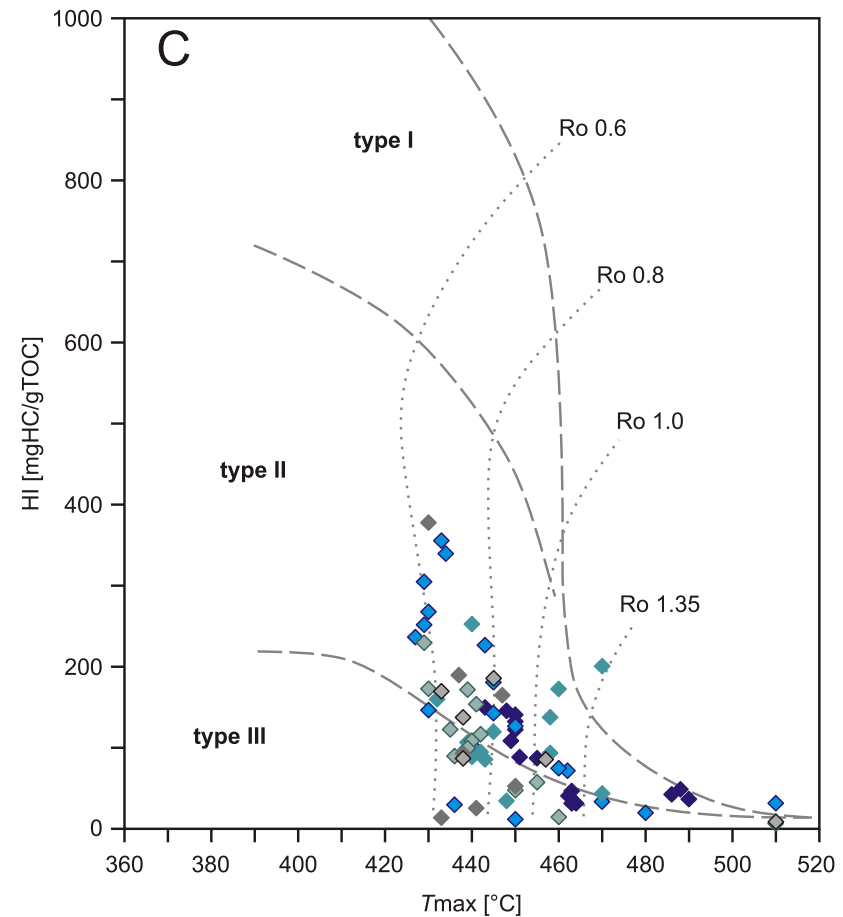

- Wenlock in the central and western Baltic Basin

$\checkmark$ Wenlock in the eastern Baltic Basin and the Lublin-Podlasie Basin

Ludlow in the central and western Baltic Basin

$\diamond$ Ludlow in the eastern Baltic Basin and the Lublin-Podlasie Basin

- Pridoli in the central and western Baltic Basin

$\diamond$ Pridoli in the eastern Baltic Basin and the Lublin-Podlasie Basin

Fig. 17. Prevailing kerogen type based on the Rock-Eval hydrogen index $(\mathrm{HI})$ versus Tmax temperature. Each data point represents an average value in an individual borehole

A - upper Cambrian and Ordovician shale, B - Llandovery shale, C - Wenlock, Ludlow and Prodoli shale 
south-east, the zone of the lower Llandovery organic-rich shale deposition narrows, and is restricted to the western limits of the EEC (Fig. 11E). In the western and central Baltic Basin, the lower Llandovery shale is developed as a good, fair to poor source rock, depending on location, whereas the upper Llandovery shale is mostly a poor source rock (Fig. 15B). In the eastern Baltic Basin and the Podlasie Depression, the lower Llandovery shale and the upper Llandovery shale have characteristics of an excellent to fair source rock, and a fair to poor source rock, respectively (Fig. 15B). The Rock-Eval HI versus Ol diagram indicates for the lower and upper Llandovery shales are of mixed type II and III kerogen (Fig. 16B), while a HI versus Tmax plot suggests the dominance of type II kerogen (Fig. 17B).

The lower part of the Wenlock section locally contains shale with an elevated TOC content, here referred to as the Mingajny shale (Fig. 9). This type of deposit is developed in the eastern part of the Baltic Basin and within the Lublin-Podlasie Basin (Fig. 11F). In the central and western Baltic Basin, the lower Wenlock shale is a poor source rock, whereas in the eastern Baltic Basin and the Lublin-Podlasie Basin it can be classified as a fair to poor source rock, depending on location (Fig. 15C). Across the whole study area, the Ludlow and Pridoli shales are poor source rocks (Fig. 15C). Organic matter of the Wenlock, Ludlow and Pridoli is characterized by a higher proportion of $\mathrm{OI}$ to $\mathrm{HI}$, in relation to the previously discussed shale formations (Fig. 16C). And, a diagram illustrating $\mathrm{HI}$ versus Tmax for these deposits indicates mixed type II and III kerogen (Fig. 17C), confirming their low quality as hydrocarbon source rocks.

All these data indicate that the lower Paleozoic organic-rich shales of the Baltic-Podlasie-Lublin Basin analysed contain organic matter with mainly oil-prone kerogen of type II, typical of most of the North American shale petroleum provinces. A general dominance of type II kerogen is related to the depositional environment, as well as to the lack of plant vegetation on Earth during most of the early Paleozoic, resulting in the absence of humic organic matter of continental origin in sedimentary basins of that age. Type I kerogen is, in this case, excluded due to the typical marine environment. Apparent mixture of type II and III kerogen within some of the shale formations analysed results from an elevated Rock-Eval oxygen index, and reflects the chemical composition of the organic matter, rather than its origin. The original hydrogen index of the lower Paleozoic shale in the study area in the net pay intervals might have varied between 300-600 (Table 1).

In shale formations, the gamma ray log readings are usually closely related to the TOC content distribution, since both an elevated natural radioactivity and an elevated concentration of organic matter are commonly related to sedimentary condensation (e.g., Leventhal, 1981; Luening and Kolonic, 2003). Moreover, organic matter might act as a redox trap, allowing for uranium adsorption (Spirakis, 1996; Puskarczyk, 2019). The gamma ray log is, therefore, often used as a substitute for TOC measurements, particularly where there is a lack of core samples for laboratory analysis. In the Baltic-Podlasie-Lublin Basin, there is a generally close correlation between gamma ray intensity, content of radioactive mineralogical components, and TOC content (Kosakowski et al., 2016; Krakowska et al., 2016; Jarzyna et al., 2017). A particularly high content of radiogenic components, mainly uranium, is characteristic of the organic-rich Alum shale in southwestern Scandinavia, which for that reason is often referred to as a "hot shale" (Lewan and Buchardt, 1989; Schovsbo, 2002; Schovsbo et al., 2018). Very high gamma ray readings are typical also of the lower part of the Jantar Formation (lower Rhuddanian). The Upper Ordovi- cian-lower Silurian shales in the Baltic-Podlasie-Lublin Basin are characterized by the gamma ray values predominately of 100-200 API, which indicate moderate to low quality shale (Table 1).

\section{NET THICKNESS OF ORGANIC-RICH SHALE}

In the lower Paleozoic Baltic-Podlasie-Lublin Basin, the net organic-rich shale reservoir thickness varies across the basin, although in general remains moderate to low, and is one of the main exploration risk factors. Its lateral changes are illustrated for individual organic-rich shale formations in Figure 18, with the use of a 2 wt.\% TOC content cut-off, except for Figure 18E, where an alternative $1.5 \mathrm{wt} . \%$ cut-off was applied. The upper Cambrian to lower Tremadocian Piaśnica Formation is characterized by a very high net-to-gross ratio (Więcław et al., 2010). The thickness of organic-rich shale in this formation is very high in the western offshore Baltic Basin, where it exceeds $35 \mathrm{~m}$ at most (Fig. 18A; Więcław et al., 2010). However, the offshore zone has no commercial potential due to the high costs of drilling and completion. Across the major part of the onshore Baltic Basin, the Piaśnica Formation is missing, or is very thin. Nonetheless, in the northwestern part of the onshore Baltic Basin in Poland, roughly an equivalent of the northwestern Łeba Elevation, the net thickness of the organic-rich Piaśnica Formation shale increases to $24 \mathrm{~m}$ at most (Fig. 18A). The net thickness of the formation is laterally highly variable there, and it is greater in small, local depocentres. Significant lateral changes of its thickness over very limited distances are particularly well-documented in numerous boreholes in the vicinity of the arnowiec-Dębki and Białogóra oil and condensate fields. Farther west, borehole control on the thickness of the Piaśnica Formation is sparse. Taking into account the very high TOC content of the Piaśnica Formation (Fig. 15A), on the northwestern Łeba Elevation it could be an individual shale gas/oil exploration target. Farther south-east, in the northeastern Podlasie Depression, the lower Tremadocian Białowie a Formation, also very rich in TOC (Fig. 15A), is characterized by a very low net thickness, $<2$ m (Fig. 18A; Kosakowski et al., 2016), and therefore has no potential as an unconventional reservoir.

The organic-rich shale of the Sasino Formation is developed across a broader area. Its net thickness varies greatly laterally. Generally a high net thickness characterizes organic-rich shale of this formation in the western offshore Baltic Basin, where it is mostly $>10 \mathrm{~m}$, while it may locally reach $25 \mathrm{~m}$ (Fig. 18B). However, the net thickness of the Sasino shale in this zone is poorly constrained, since little core data or wire logs are available in public domain. In the approach adopted here, its offshore net thickness was determined by reduction of its gross thickness in proportion to the net-to-gross ratio adopted from the better constrained onshore part of the basin. This results in considerable error bars in the analysis. Nonetheless, as in the case of the Piaśnica Formation, the offshore zone of the Sasino Formation has no commercial potential for shale gas/oil exploration.

In the onshore Baltic Basin, the highest net thickness of the organic-rich Sasino Formation shale is characteristic of the northern Łeba Elevation, where its maximum value reaches $24 \mathrm{~m}$ (Fig. 18B). In that zone the Sasino Formation, is characterized also by a high TOC content of 3-5 wt.\% on average per borehole (Fig. 15A), might be an individual shale gas/oil exploration target. Farther west, south and eastwards within the Polish part of the Baltic Basin, the net thickness of this formation decreases 


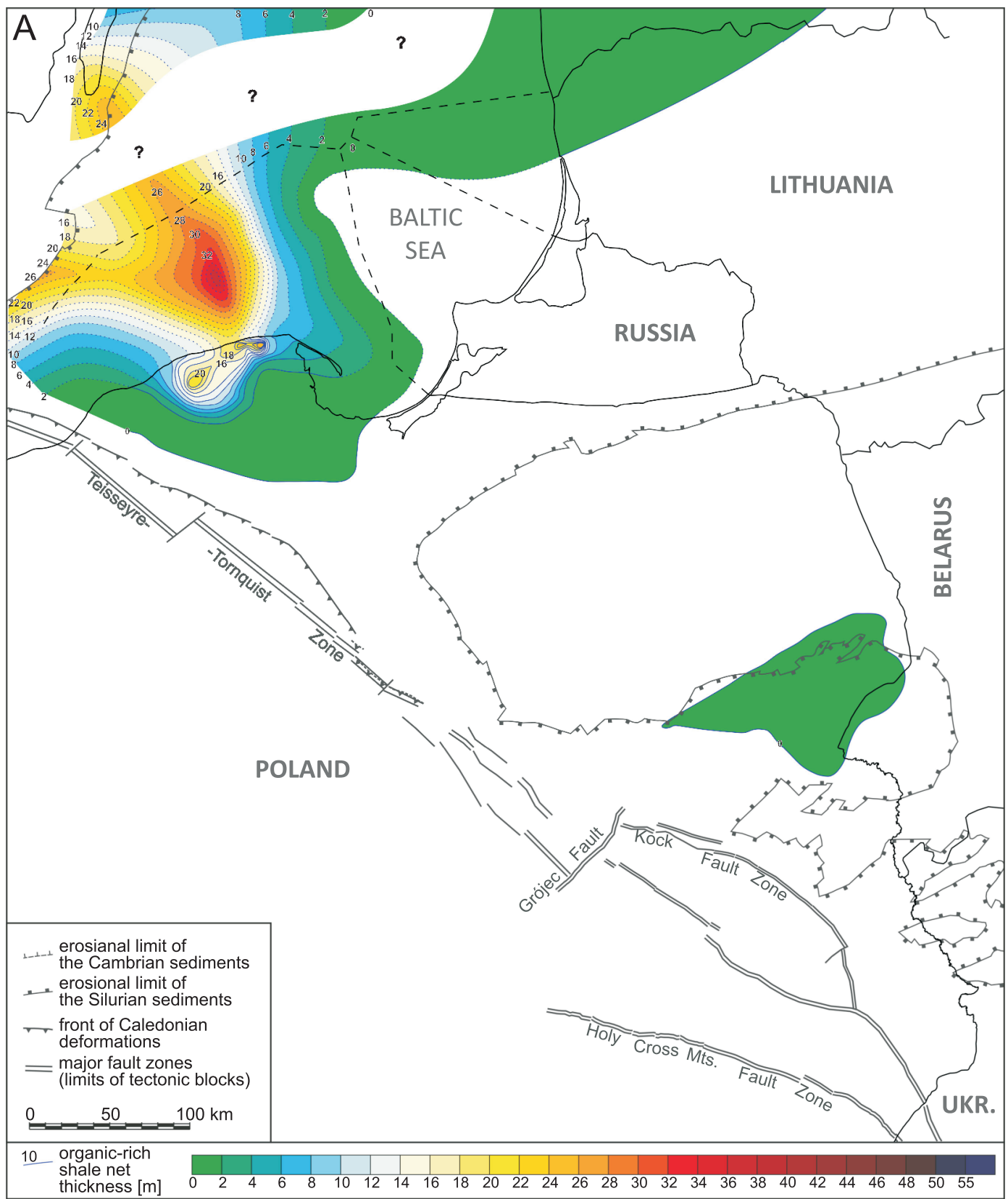

Fig. 18. Thickness of organic-rich shale in the Baltic-Podlasie-Lublin Basin

A - upper Cambrian to lower Tremadocian shale (Piaśnica and Białowieża Formations). In Figure B and C, the data for Lithuania after Zdanaviciute and Lazauskiene (2007), Zdanavičiūtè and Lazauskienè (2009), Bičkauskas et al. (2016), Sliaupa et al. (2016), Cichon-Pupienis et al. (2020). Offshore net thickness determined by reduction of gross thickness in proportion of the net-to-gross ratio adopted from the better constrained onshore part of the basin, supported with data of Wieccław et al. (2010) and Podhalańska et al. (2016). Data for Alum Shale in Scandinavia after Andersson et al. (1985), Schovsbo (2002), Schovsbo et al. (2011), Rasmussen et al. (2017). TOC content cut-off for $A$ to $D$ is $2 \%$, while for $E$ it is $1.5 \%$

significantly. An elevated thickness of its lateral equivalents is documented in western Lithuanian onshore, where for the Upper Ordovician organic-rich shale of the Fjacka Formation and the Mossen Formation it typically ranges between 6-10 m (Fig. 18B; Zdanavičiūtè and Bojesen-Koefoedet, 1997; Bičkauskas et al. 2016; Cichon-Pupienis et al., 2020). Another zone with elevated net thickness of the organic-rich Sasino Formation shale is the basement of the Płock-Warsaw Trough, where is reaches $16 \mathrm{~m}$ at most (Fig. 18B). Farther south-east its thickness decreases, and in the western Podlasie Depression the organic-rich Sasino Formation shale is only a few metres thick. The lateral equivalents of the Sasino Formation in the Lublin Basin, i.e. the Udal shale and the Włodawka marl, are organic-lean.

The lower Llandovery ( Rhuddanian) Jantar Formation, is composed mainly of organic-rich shale. Its high net thickness is identified in the central part of the onshore Baltic Basin in the 


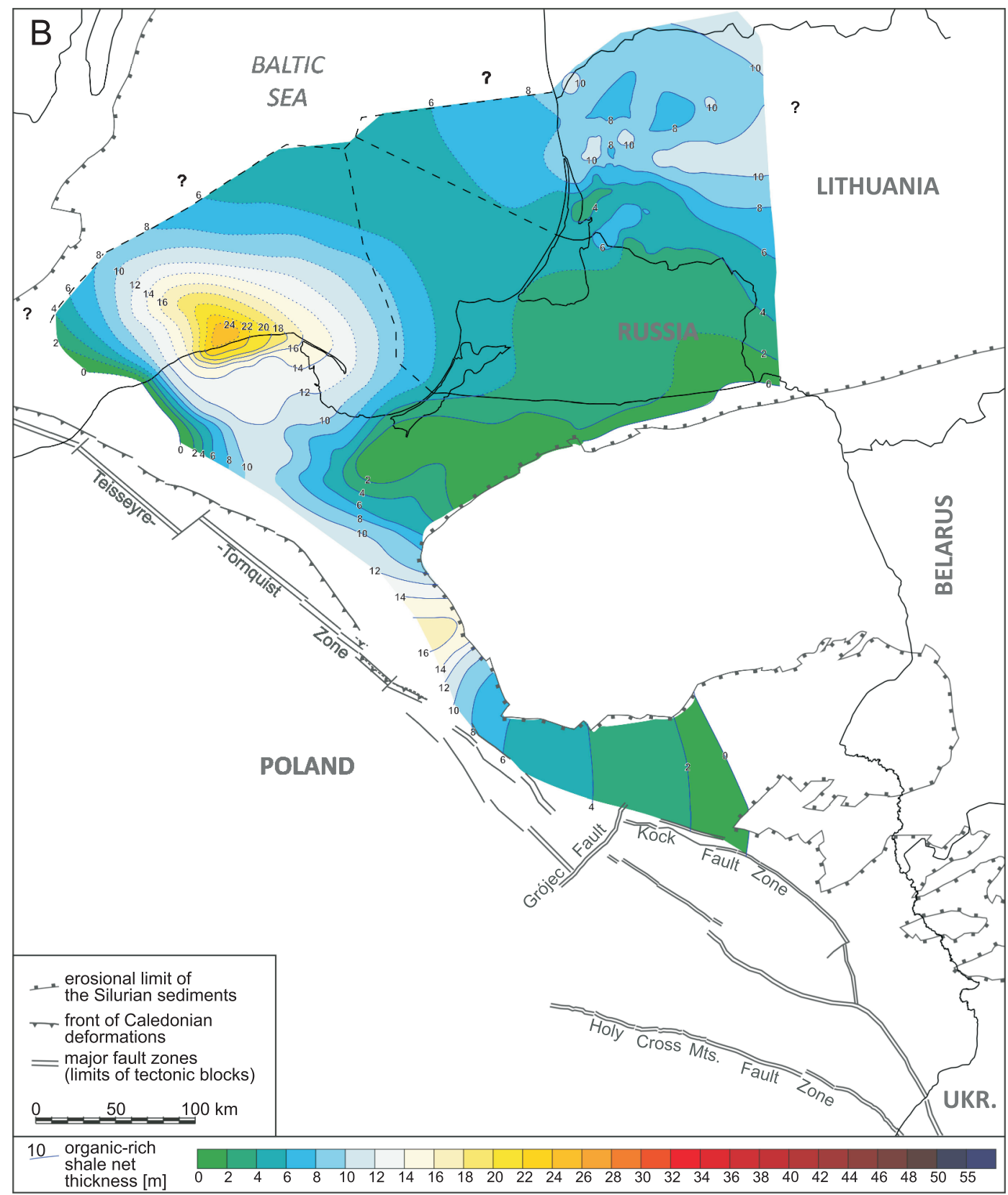

Fig. 18. Thickness of organic-rich shale in the Baltic-Podlasie-Lublin Basin

B - upper Ordovician (Sasino Formation); for other explanations see Figure 18A

zone located to the west of city of Gdańsk (Fig. 18C). There, the organic-rich shale net thickness exceeds $16 \mathrm{~m}$ at most. Taking into account its high TOC content average per borehole of 3-4 wt.\% (Fig. 15B), it allows consideration of the Jantar Formation at this location as an individual shale gas/oil exploration target. According to Podhalańska et al. (2016), the zone of increased thickness of the Jantar Formation shale continues to the south, towards the Kościerzyna IG 1 borehole, as well as to the north, towards the Żarnowiec IG 1 borehole, and farther north into the offshore basin. In the western and southern Baltic Basin, the net thickness of the Jantar Formation shale is considerably lower, and in the westernmost Baltic Basin the Jantar Formation in such a development is missing. In the eastern part of the Polish onshore Baltic Basin, there are small local depocentres with elevated net thickness of the Jantar Formation organic-rich shale, which reaches $10 \mathrm{~m}$ at most (Fig. 18C).
At that location the Llandovery organic-rich shale is deposited on top of the Barciany Limestone (Fig. 9B), a potential tight oil reservoir.

Another zone characterized by elevated thicknesses of the Llandovery organic-rich shale is located in the western Lithuania, where it reaches roughly $10 \mathrm{~m}$ at most (Fig. 18C; Bičkauskas et al., 2016; Cichon-Pupienis et al., 2020). The Llandovery Dobele Formation, together with the upper Caradocian Fjacka and Mossen formations, are regarded as major shale oil/gas targets in Lithuania (Zdanavičiūtè and Lazauskienè, 2009; Sliaupa et al., 2016; Cichon-Pupienis et al., 2020). In the offshore Baltic Basin of Kaliningrad region, the net thickness of the strata analysed is poorly constrained. As in the case of Sasino Formation, it is determined here by reduction of its gross thickness in proportion to the net-to-gross ratio adopted from nearby, better studied zones. 


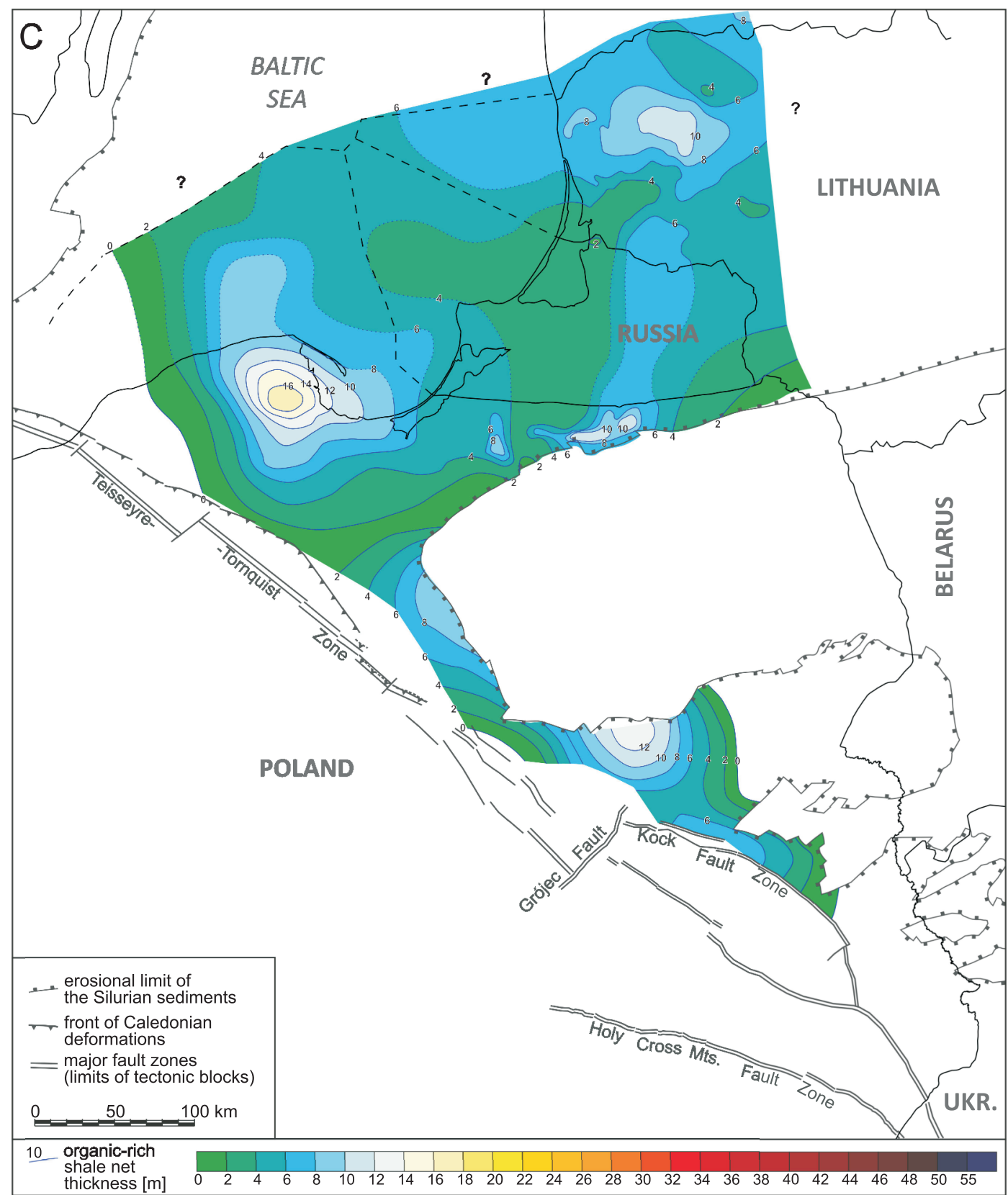

Fig. 18. Thickness of organic-rich shale in the Baltic-Podlasie-Lublin Basin

C - lower Llandovery (Jantar Formation); for other explanations see Figure 18A

To the south-east of the Baltic Basin, the net thickness of the lower Llandovery Jantar Formation organic-rich shale slightly increases, and in the Płock-Warsaw Trough it reaches $8 \mathrm{~m}$ at most (Fig. 18C). A zone with considerable elevated thickness of these strata is located also in the northwestern part of the Podlasie Depression, where it locally it exceeds $12 \mathrm{~m}$ (Fig. 18C). The Jantar Formation shale there is very rich in TOC, the average content of which might be as high as $7 \%$ or more (Fig. 15B). Taking this into consideration, the Jantar Formation in the northwestern part of the Podlasie Depression might be considered as an individual shale gas/oil exploration target, although of limited potential due to its moderate thickness. The extent of the organic-rich facies of the Jantar Formation continues into the north-western part of the Lublin re- gion. Farther south-east it is replaced by organic-lean facies, and subsequently by a hiatus.

Another potential shale reservoir of the Baltic-Podlasie-Lublin Basin is the uppermost Llandovery and lower Wenlock Mingajny shale. The average TOC content of this shale is, however, considerably lower than that of the other formations discussed. The net thickness of the organic-rich Mingajny shale, considered as shale exceeding $2 \mathrm{wt} . \%$ TOC, is usually $<10 \mathrm{~m}$, except for the northwestern Podlasie Depression and the western part of the central Lublin region, where is reaches 16 and $12 \mathrm{~m}$, respectively (Fig. 18D). Nonetheless, a significant part of the gross Mingajny shale section is composed of strata with TOC contents within a range of $1.5-2 \%$ (Fig. 15C). Therefore, an alternative cut-off of organic-rich shale, equal to $1.5 \mathrm{wt} . \%$ TOC, might better characterize the shale gas/oil potential of the 


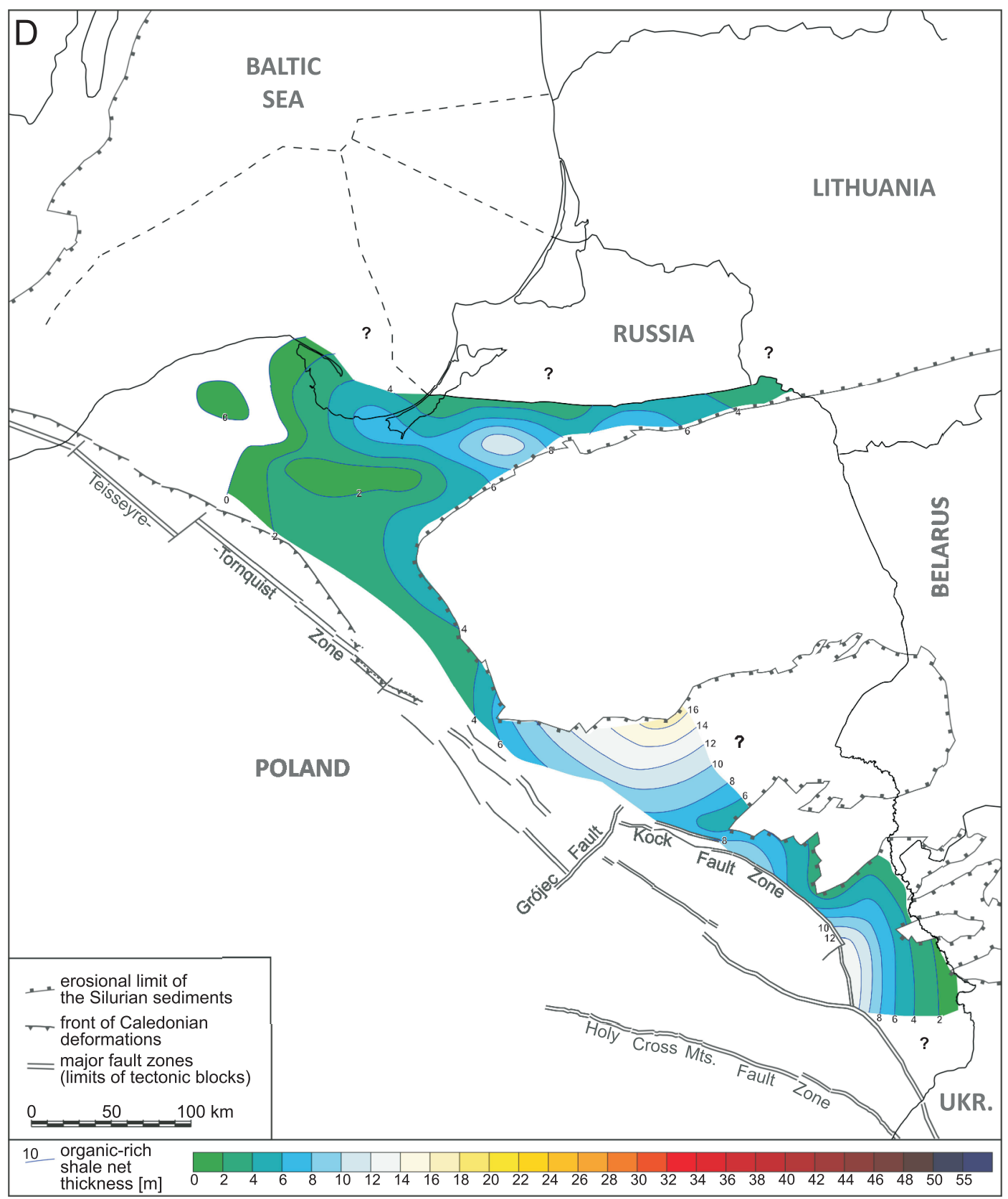

Fig. 18. Thickness of organic-rich shale in the Baltic-Podlasie-Lublin Basin

D - lower Wenlock (Mingajny shale); for other explanations see Figure 18A

Mingajny shale. Its application results with identification of the zones of particularly high net thickness in the eastern part of the Baltic Basin, the western part of the Podlasie Depression, and the central part of the Lublin region, where its maximum thicknesses reach 42, 36, and $30 \mathrm{~m}$, respectively (Fig. 18E). In those zones, therefore, the low TOC content is to some extent compensated by the high gross thickness of the shale reservoir. In general, both with application of the TOC content cut-off of $2 \mathrm{wt} . \%$, as well as with one of $1.5 \mathrm{wt} . \%$, the net thickness maps illustrate a significant eastwards and south-eastwards shift of organic-rich shale deposition in relation to the Jantar Formation and the Sasino Formation. It supports the concept of diachronism of the starved basin development, as discussed in previous sections (Fig. 13; Poprawa, 2010a).
The zones of the best development of the four above-discussed potential shale reservoir formations partly overlap. Furthermore, the strata separating them in a section, which could be potential frac barriers, are often of limited thickness. Therefore, shale oil/gas potential might be considered for a combination of two or three formations, rather than individually. The Jantar Formation and the Sasino Formation might be considered as one combined exploration target. Their net organic-rich shale cumulative thickness is relatively high in the central part of the Polish onshore Baltic Basin, particularly on the Łeba Elevation, where it reaches 35 m (Figs. 14 and 18A, B). In the central part of the Baltic Basin and in the Płock-Warsaw Trough, the subject for shale gas/oil exploration might be the Piaśnica and Sasino formations together. Their cumulative thickness of organic-rich shale usually exceeds $20 \mathrm{~m}$ there. In the northern 


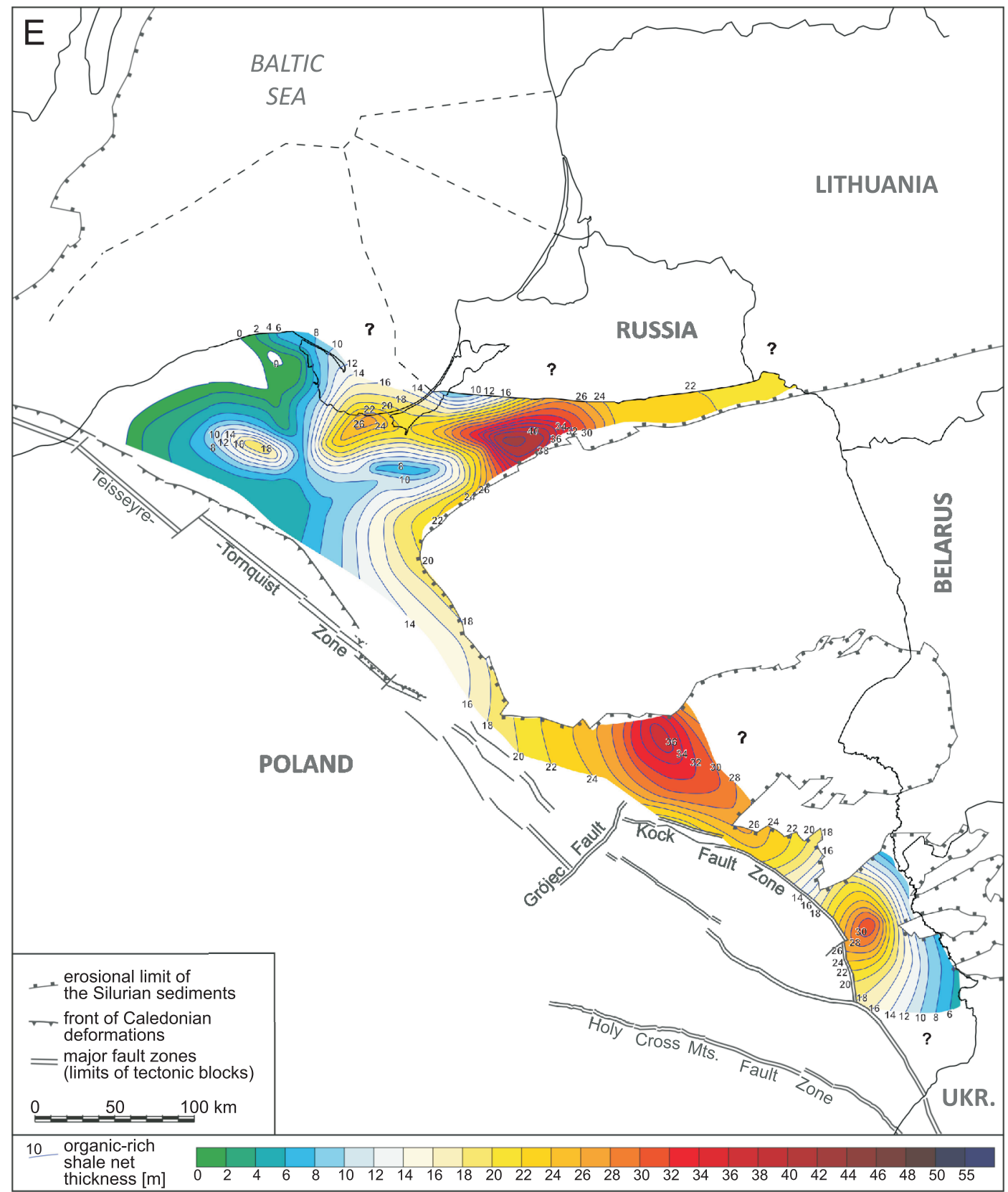

Fig. 18. Thickness of organic-rich shale in the Baltic-Podlasie-Lublin Basin

E - lower Wenlock (Mingajny shale); for other explanations see Figure 18A

and eastern parts of the Łeba Elevation it is up to $35 \mathrm{~m}$, while in the central part of the Płock-Warsaw Trough it reaches $25 \mathrm{~m}$ (Fig. 18B, C).

The other zone characterized by a relatively high cumulative thickness of net organic-rich shale formations is the western part of the Podlasie Depression and the northwestern part of the Lublin region, where the organic-rich shale of the Jantar Formation and Mingajny shale could be considered as a common shale oil/gas exploration target. In the northwestern part of the Podlasie Depression, the cumulative thickness of shale with TOC content $>2 \mathrm{wt} . \%$ within the two formations locally exceeds $25 \mathrm{~m}$ (Fig. 18C, D). However, if one was to apply an alternative
TOC content cut-off, of $1.5 \%$, the cumulative thickness of organic-rich intervals of both the formations is locally up to $50 \mathrm{~m}$.

Apart from the Lublin-Podlasie Basin, similar net pay stratigraphic intervals are recognized in the Biłgoraj-Narol Zone. These are the Tremadocian Goraj Member, the lower Llandovery Jantar Formation, and the uppermost Llandovery to lower Wenlock Mingajny shale (Fig. 9F). The net thickness of the Goraj Member is equal to 17-41 m (Poprawa et al., 2016), although the number of laboratory TOC content measurements is here limited. This remains a separate exploration target, since the Middle and Upper Ordovician strata dividing it from the potential pay intervals above have high thickness, exceeding 100 
m. The uppermost Llandovery to lower Wenlock Mingajny organic-rich shale intervals, divided from each other by some 30 $\mathrm{m}$ of organic-lean shale, could be regarded as a common potential exploration target. The net organic-rich thickness of shale of the Jantar Formation and the Mingajny shale in the Biłgoraj-Narol Zone, is $10-15 \mathrm{~m}$ and $30-50 \mathrm{~m}$, respectively (Fig. 14; Poprawa et al., 2016).

\section{BURIAL DEPTH AND THERMAL MATURITY}

In the Baltic-Podlasie-Lublin Basin, the burial depth of the shale formations analysed varies greatly laterally. In general, the burial depth increases from the north-east to the south-west, from <500 to >8000 m (Fig. 19; Poprawa, 2010a, 2019). This lateral change of burial depth reflects both the westward flexure of the Caledonian foredeep basin, as well as the lateral changes in thickness of the upper Permian and Mesozoic succession. In the Lublin region, the burial depth of the lower Paleozoic shale is additionally influenced by the thickness of the upper Paleozoic succession.

A high lateral gradient of burial depth of the lower Paleozoic succession in a relatively narrow zone is characteristic of the Lublin region (Poprawa, 2019). In the northeastern part of the region the burial depth is $<1000 \mathrm{~m}$, while in its southwestern part it exceeds $5000 \mathrm{~m}$ (Fig. 19). The southwestern limits of the Lublin region are, therefore, too deep for shale gas/oil exploration and production. Exceptionally high burial depth, in the range of roughly $5000-7000 \mathrm{~m}$, characterizes the lower Paleozoic succession in the Lublin Trough, although it has never been confirmed by deep enough boreholes. Farther west, in the Biłgoraj-Narol Zone, the burial depth of the Upper Ordovician to lower Silurian shale is much lower, in most of the area equal to 1000-3000 m (Fig. 19; Poprawa, 2019). A low burial depth in this zone is a result of Variscan thrusting and uplift (Krzywiec et al., 2017). On the adjacent Małopolska Block the burial depth of the erosional patches of the Upper Ordovician and lower Silurian shale increases from the north and north-west towards the south and south-east, from $\sim 1000-2000$ to $>5000 \mathrm{~m}$, respectively (Poprawa, 2019). This is mainly due to lateral changes in thickness of the Miocene sedimentary fill of the Carpathian Foredeep Basin, as well as, in the southern part of the area, to burial beneath the Outer Carpathians. In the southern part of the Małopolska Block, the high burial depth of the unconventional reservoir is beyond the depth range acceptable from the shale gas/oil point of view.

In the Podlasie Depression, a smooth westwards increase of the lower Paleozoic shale burial depth is observed (Fig. 19). In the eastern part of the Podlasie Depression, around the Poland and Belarus border, the burial depth of the Upper Ordovician and lower Silurian shale is very low, and does not exceed $1000 \mathrm{~m}$. The central part of Podlasie Depression is also characterized by a low burial depth of the shale reservoirs analysed, of roughly 1000-2000 m, while in the western margins of this unit, to the west of the Okuniew IG 1 borehole, the burial depth significantly increases to 5000-6000 m (Poprawa, 2019). The latter depth range is too high for shale gas/oil exploration and production. In the most prospective zone of the Podlasie Depression, located north-east of Warsaw, the burial depth of the target formation is $3000 \mathrm{~m}$ (Fig. 19). A large burial depth of the shale analysed, ranging between 3500 and $5500 \mathrm{~m}$, is characteristic of the basement of the Płock-Warsaw Trough, the tectonic unit located west of the Mazury High (Fig. 19).

The Baltic Basin is a regional syneclise, well-expressed by the map of recent burial depth to the top of the Upper Ordovician (Fig. 19). In the eastern and northern parts of the Baltic Ba- sin it is <500-1000 m (Paškevičius, 1997; Sakalauskas, 2001; Zdanavičiūtẻ and Lazauskienè, 2009; Sopher et al., 2016), and increases towards the west and south-west. Within the onshore territory of Poland the burial depth of the strata analysed varies from roughly $1000-2500 \mathrm{~m}$ in its eastern part, to 2500-3500 m in the central part (Poprawa, 2010a, 2019). A relatively low burial depth characterizes, in particular, the northern part of Łeba Elevation (Fig. 19). A large burial depth of the Upper Ordovician and lower Silurian shale in the western and southwestern parts of the Baltic Basin, ranging from roughly $4000 \mathrm{~m}$ to $>8000 \mathrm{~m}$ (Poprawa, 2019), is constrained by boreholes, and in the westernmost margin of the basin also by new deep seismic data (Krzywiec et al., 2014; Mazur et al., 2016; Tari et al., 2016). With the recent technological and commercial constraints, such shale reservoir burial depths significantly limit commercial potential for shale gas/oil exploration there.

In the Baltic-Podlasie-Lublin Basin, the burial depth of the lower Paleozoic succession is closely related to its thermal maturity (cf. Figs. 19 and 20). The latter is constrained by numerous studies (e.g., Grotek, 1999, 2005, 2006, 2016; Klimuszko, 2002; Zdanavičiūtè and Lazauskienè, 2009; Poprawa, 2010a; Więcław, 2010; Caricchi et al., 2015; Cichon-Pupienis et al., 2020), the results of which, however, are not entirely consistent. Some degree of uncertainty is related in particular to vitrinite reflectance studies due to a general lack of humic organic matter in early Paleozoic rocks. For this reason thermal maturity analyses were conducted on other, subsidiary organic components, such as alginite, bitumen, acritarchs or graptolites, and as a consequence of this there are broad error bars on the measurements.

In the current contribution the thermal maturity of the Baltic-Podlasie-Lublin Basin is shown in Figure 20 with the map of vitrinite reflectance for the top Caradoc. This is, however, roughly representative for other here analysed shale formations analysed here, since the top Caradoc structural level is separated from the deepest and shallowest potential shale reservoirs by a few tens of metres of organic-lean deposits only. Within each region of the study area, the thermal maturity is generally low in the eastern and northeastern limits of the basins, and considerably increases towards the south west (Fig. 20), as the burial depth does (Fig. 19).

Within the Lublin region, the thermal maturity of the lower Paleozoic shale varies significantly from the north-east to the south-west over a small lateral distance (Fig. 20). In its northern and northeastern limits, the organic-rich shale is immature. The thermal maturity increases southwards and westwards, although in the central and northwestern part of the region it does not reach a dry gas window, and the target shale is matured to the oil or condensate (wet gas) window only (Figs. 20 and 21). The major hydrocarbon product which could be produced from the Wenlock shale reservoir in this part of the basin is, therefore, oil and condensate. In the southern part of the Lublin region and in the northern part of the Volyn-Podolia-Moldova Basin, a smooth increase of the lower Paleozoic shale thermal maturity towards the south-west is observed, and its maturity changes in this direction form the equivalent of the oil window, through the liquids window and dry gas window, to overmature (Figs. 20 and 21). To the west of the Kock Fault Zone, in the Lublin Trough, the lower Paleozoic shale is within the dry gas window, or is overmature.

In the Biłgoraj-Narol Zone, the Upper Ordovician and lower Silurian shale are matured to the dry gas window, with the measured values of thermal maturity being mostly in the range of 1.3 to $2.0 \%$ Ro (Figs. 20 and 21). Thermal maturity at the level of the dry gas window characterizes also the lower Paleozoic succession in the southern part of the Łysogóry Block, although ex- 


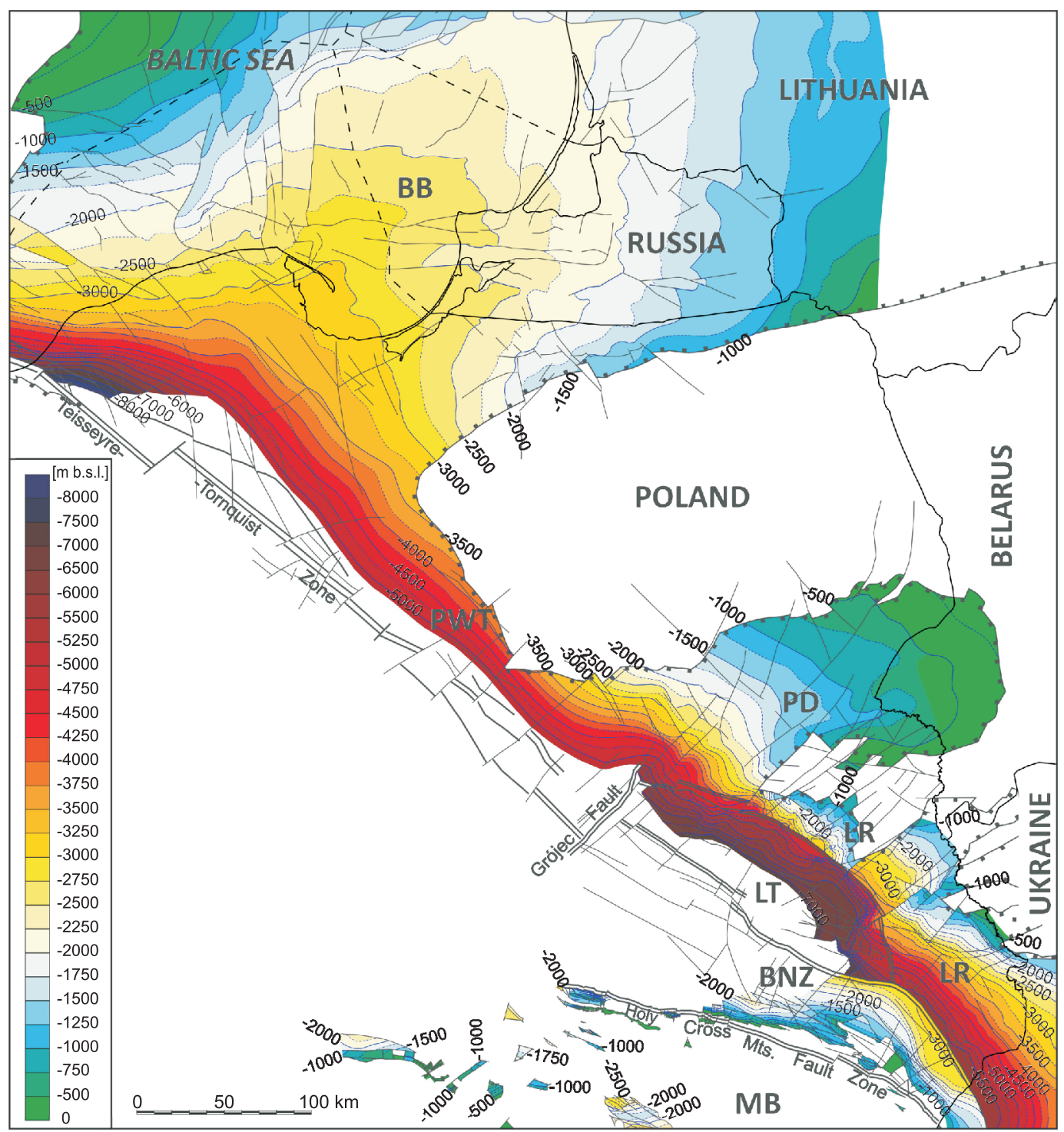

Fig. 19. Recent burial depth to the top of the Caradoc in the Baltic-Podlasie-Lublin Basin, the Biłgoraj-Narol Zone, the Małopolska Block, and surrounding areas

After Poprawa (2019). Data for Lithuania after Sakalauskas (2001); BB - Baltic Basin, PWT - Płock-Warsaw Trough, PD - Podlasie Depression, LR - Lublin region (referred to also as the Lublin slope of the EEC), LT - Lublin Trough, BNZ - Biłgoraj-Narol Zone, MB - Małopolska Block

act values of thermal maturity are higher than in the previous zone, and equal to $1.5-3.0 \%$ Ro. On the Małopolska Block, the thermal maturity of the Upper Ordovician and lower Silurian shale is considerably lower. It increases from the north and north-west towards the south and south-east, from 0.9 to $1.5 \%$ Ro, respectively. However, noticeably lower maximum thermal maturity values for that zone, equal to $0.9 \%$ Ro, are reported by Kotarba et al. (2011).

Within the Podlasie Depression, the thermal maturity of the shale formations analysed increases from the north-east to the south-west, from zone of immature shale, through the oil and condensate windows, to the dry gas window (Figs. 20 and 21). The Białowieża shale Formation, located in the northeastern part of the Podlasie Depression, which is characterized by very high average TOC content, remains immature. In the most prospective zone of this region, located north-east of Warsaw, the shale is saturated with light oil, condensate and wet gas (Fig. 21). At the westernmost limits of the Podlasie Depression, and farther north-west within the Płock-Warsaw Trough, the thermal maturity of the lower Paleozoic shale is higher, being equivalent to either the dry gas window, or the shale is overmature (Figs. 20 and 21).

In the Baltic Basin, there are similar lateral trends of thermal maturity change as in the cases discussed above. The Upper Ordovician to lower Silurian shale in western Lithuania is characterized by thermal maturity typically in the range of $0.6-1.1 \%$ Ro, although a local anomaly with elevated thermal maturity is identified in southwestern Lithuania (Zdanavičiūtè and Lazauskiené, 2009; Sliaupa et al., 2016; Cichon-Pupienis et al., 2020). Similar thermal maturity is observed in the Kaliningrad region and the eastern offshore Baltic Basin (Fig. 20), although in these regions it is poorly constrained by data. Therefore, in the eastern part of the Baltic Basin the upper Ordovician to lower Silurian organic-rich shale is mostly in the black oil window (Fig. 21), presumably too heavy for production from an unconventional reservoir. The exception is a region in southwest- 


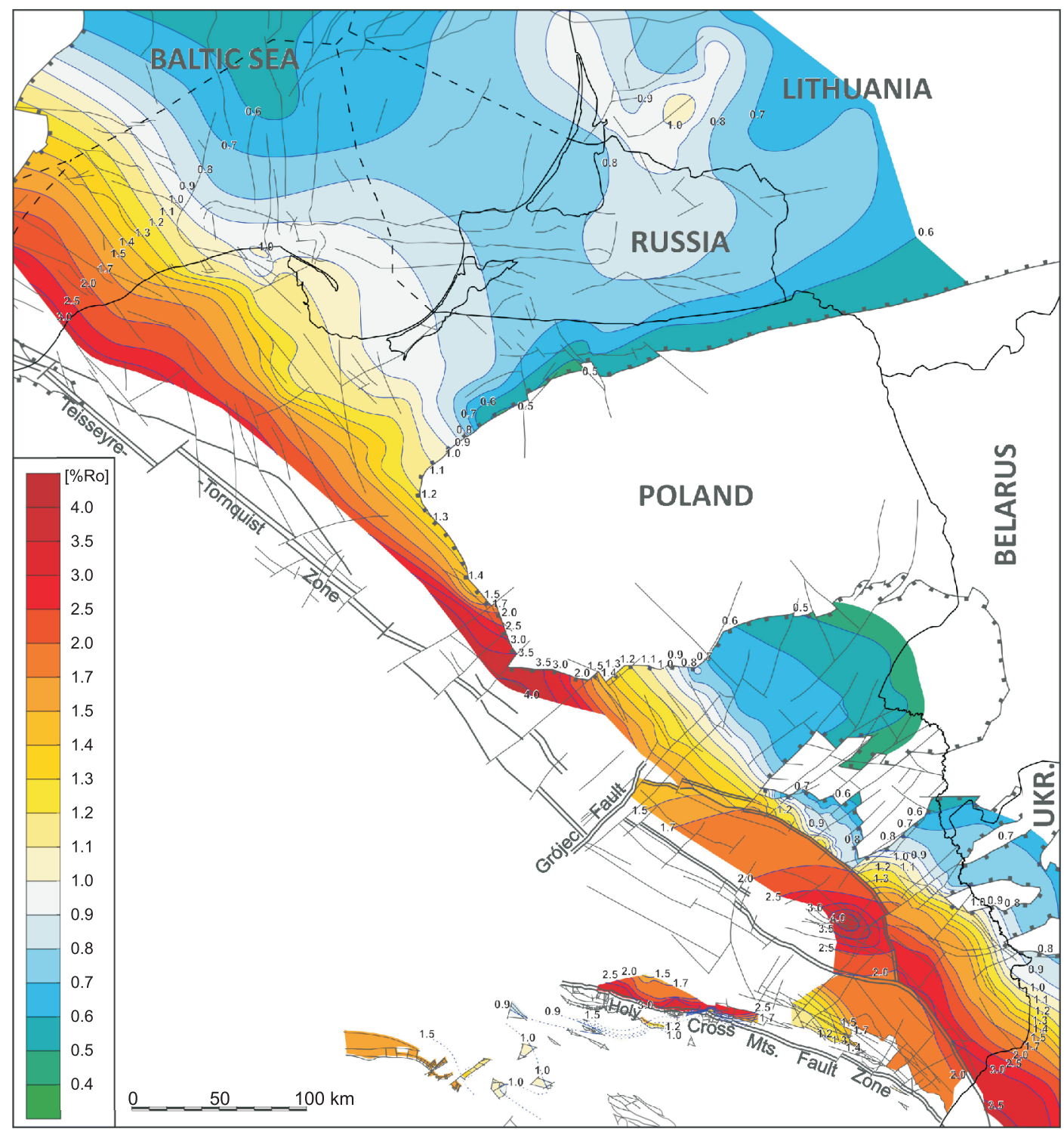

Fig. 20. Thermal maturity map for the top Caradoc in the Baltic-Podlasie-Lublin Basin, the Biłgoraj-Narol Zone, the Małopolska Block, and surrounding areas

Data for Lithuania after Zdanavičiūtè and Lazauskienẻ (2009) and Sliaupa et al. (2016)

ern Lithuania near the Curonian Bay, where the shale is in a volatile oil window, suitable for shale oil exploration. In the Polish part of the eastern Baltic Basin the thermal maturity decreases southwards, and in a zone neighbouring the Mazury Uplift to the north, the upper Ordovician to lower Silurian shale remains immature (Fig. 21). This might indicate also, that the recently observed thermal maturity in that zone developed after uplift and denudation of the Mazury High.

Farther to the west and south-west in the Baltic Basin, the thermal maturity of the upper Ordovician to lower Silurian shale systematically increases towards the EEC margin (Grotek, 1999, 2006; Poprawa, 2010a). In the central part of the Polish onshore Baltic Basin, the unconventional shale reservoirs are characterized by thermal maturity in the range of roughly $0.7-0.8$ to $1.2-1.3 \%$ Ro (Fig. 20), being equivalent to the volatile oil to wet gas (condensate) window (Fig. 21). On the northern part of the Łeba Elevation, i.e. the zone of the highest net pay thickness of the lower Paleozoic unconventional shale res- ervoirs (Fig. 18A-C), the thermal maturity of the shale formations varies between $0.95 \%$ Ro in its northeastern limits and $1.2-1.3 \%$ Ro in the southern and southwestern parts (Fig. 20). Therefore, the zone most prospective for shale oil/gas exploration is mostly within the volatile oil to wet gas (condensate) window (Fig. 21). Farther to the south-west, the thermal maturity of the shale formations analysed systematically increases, and across most of the western and southern part of the basin they are in the dry gas window (Fig. 21). At the southwestern limits of the basin, i.e. the zone adjacent to the TESZ, the Ordovician and lower Silurian shale is overmature.

Across the whole Baltic-Podlasie-Lublin Basin, there is a coherence between thermal maturity of the lower Paleozoic shale and the types of hydrocarbons saturating the conventional and unconventional lower Paleozoic reservoirs (Fig. 21). This independently confirms that the current model of thermal maturity shown in Figure 20 is correct. Some local inconsistencies between thermal maturity and the type of hydrocarbon flu- 


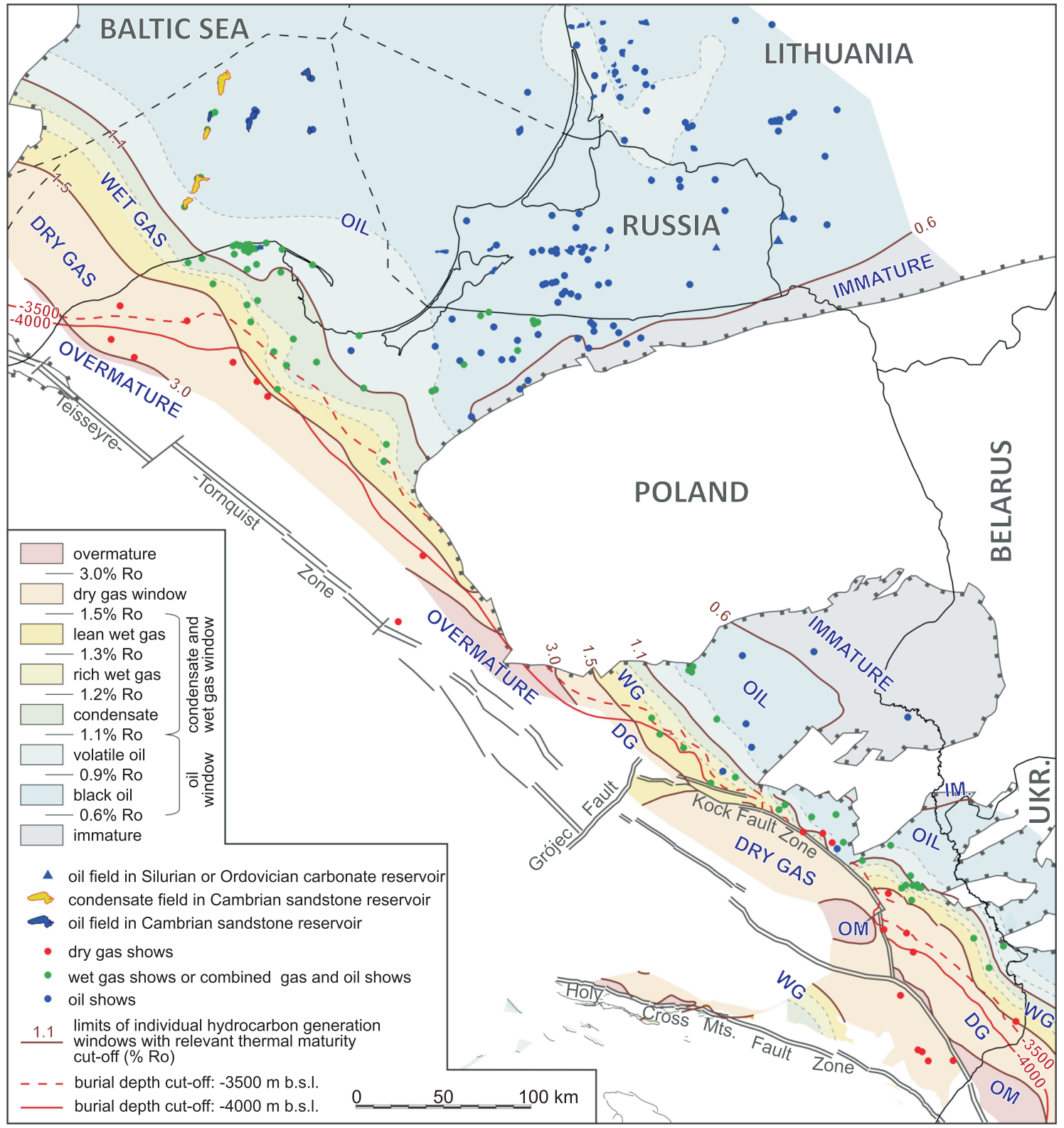

Fig. 21. Hydrocarbon generation windows for the top Caradoc, as well as lateral distribution of hydrocarbon fields and shows, in the Baltic-Podlasie-Lublin Basin, the Biłgoraj-Narol Zone, the Małopolska Block, and surrounding areas

Hydrocarbon generation windows after Jarvie (2016); hydrocarbon generation windows based on data from Figure 20; data for Lithuania and Kaliningrad after Ulmishek (1990), Jacyna et al. (1997) and Baltrūnas (2004); DG - dry gas window, IM - immature, OM - overmature, WG - wet gas (condensate), UKR. - Ukraine

ids at a given location are related to lateral migration of hydrocarbons within a conventional reservoir on a limited lateral scale. At some locations, this results in the hydrocarbon fluids being lighter than might be expected from the thermal maturity of the local source rock. This is represented in particular by oil shows in immature zones, and to lesser degree by the presence of condensate in the oil window.

In the zone of maturation being equivalent to the oil window, a general dominance of oil fields and shows is observed (Fig. 21). The presence of condensate fields in the Polish offshore Baltic Basin at a considerable distance from the condensate kitchen results from lateral migration either along permeable middle Cambrian sandstone, or along the conductive
Smołdzino (Łeba) Fault Zone. The presence of gas shows in the volatile oil window represents associated gas, typical for that thermal maturity range. In the wet gas window, shows of condensate, or combined gas and oil shows, are documented (Fig. 21). Neither oil nor condensate shows are identified within the dry gas window, being instead characterized by exclusive shows of gas with a very high methane content.

In the Baltic-Podlasie-Lublin Basin, a certain burial depth range of the lower Paleozoic shale reservoirs is characteristic for each type of hydrocarbon. At burial depths $<1000 \mathrm{~m}$, the shale formations are too immature to generate hydrocarbons (cf. Figs. 19 and 21). In the zone where the shale reservoirs are within the black oil window, their burial depth usually does not 
exceed $2300-2700 \mathrm{~m}$. The potential shale oil accumulations, related to the shale reservoir thermal maturity being equivalent to the volatile oil window and the lower wet gas window, are located mostly at depths of 2300-3000 m (cf. Figs. 19 and 21). The zone with the shale reservoirs analysed that potentially contain condensate accumulations is located at the depth range of 2700-3500 m, while the wet gas zone occurs at depths of 2800-4000 m. Potential dry gas accumulations are identified at depths of 3500-5000 m, except for the western part of the Łeba Elevation and the northwestern part of the Podlasie Depression, where the zone of dry gas-saturated shale reservoir could be as shallow as $2700-3000$ m, as well as in the BigorajNarol Zone, where it occurs at depths of 1000-3000 m (cf. Figs. 19 and 21). At burial depths exceeding $5000 \mathrm{~m}$, the shale reservoir is generally overmatured. Therefore, in the Baltic-Podlasie-Lublin Basin, the shale oil, the condensate and the gas accumulations are generally buried deeper than in the case of their equivalents in classic USA shale basins.

In the case of the dry gas and wet gas window, the content of non-hydrocarbon components of gas, such as $\mathrm{N}_{2}, \mathrm{CO}_{2}$, or $\mathrm{H}_{2} \mathrm{~S}$, might affect the quality of the shale petroleum play considerably. Based on legacy data from conventional lower Paleozoic reservoirs, a high nitrogen content (up to $80 \%$ ) was reported in the Baltic-Podlasie-Lublin Basin, mainly in its eastern parts, characterized by low thermal maturity (Poprawa, 2010a). Therefore, the generation of the nitrogen from highly mature organic matter or clay minerals, being a common mechanism of its origin in a sedimentary basin (e.g., Gras and Clayton, 1998; Mingram et al., 2005), in this case might be excluded. Instead, the origin of nitrogen in the Baltic-Podlasie-Lublin Basin has been related to early Carboniferous magmatic activity (Poprawa, 2010a). A consequence of this is that nitrogen could migrate into permeable conventional reservoirs, where it is identified, but not into impermeable shale reservoirs. This conclusion is consistent with the results of last decade's shale gas/oil exploration in the basin. In general, desorption analysis and production tests have revealed, apart from hydrocarbon gases, only a few present of $\mathrm{N}_{2}$ and $\mathrm{CO}_{2}$, as well as traces of helium and hydrogen. Therefore, both gas and oil in the BalticPodlasie-Lublin Basin shale reservoirs, might be regarded as of very good quality.

PETROPHYSICAL MINERALOGICAL AND GEOMECHANICAL CHARACTERISTICS

Total porosity, gas/oil filled porosity and matrix permeability of the lower Paleozoic shale reservoirs in the study area are typically moderate to low, as reported from analysis of new exploration boreholes (Table 1 and Fig. 14; e.g., Dyrka, 2016; Sowi d at et al., 2016; Ma et al., 2017; Schovsbo et al., 2017; Wawrzyniak-Guz, 2019). The porosity of the shale reservoirs analysed is related to the presence of nanopores and micropores. Apart of intragranular and fracture porosity, a significant contribution of organic porosity is observed (Ma et al., 2017).

In the study area, the total porosity varies significantly, both laterally and stratigraphically, and its average values per borehole range between 1.5 and $15 \%$. Gas-filled porosity also varies in a broad range of $1-6 \%$, although in the most prospective part of the basin, mainly within the oil and condensate window, this parameter is of lower relevance. High total porosity of the shale formations analysed, exceeding $10 \%$, is observed exclusively in the eastern part of the basin. This is because in such zones a low maximum burial depth resulted in limited mechanical compaction of the shale, which did not reduce its intra-gran- ular porosity to the degree observed farther to the south-west in the more deeply buried part of the basin. On the northern part of the Łeba Elevation, being the potential light oil and condensate producing zone, the average shale reservoir total porosity is in the range of $6-10 \%$. In the central part of the Lublin region, an area prospective mostly for condensate, the average total porosity of the shale reservoir is slightly lower, at $4-6 \%$. Few data are available for the northwestern Podlasie Depression, prospective for light oil and condensate. In the Baltic-Podlasie-Lublin Basin, the shale reservoir matrix permeability typically does not exceed 150-200 nD (Table 1). The above characteristics define the shale formations analysed as a mostly moderate to low, locally good quality unconventional reservoir.

The gas saturation of the lower Paleozoic shale reservoir in the Baltic-Podlasie-Lublin Basin, reported by industry as typically $1.5-2.0 \mathrm{~m}^{3}$ /ton, could be regarded as relatively low and might be considered as an exploration risk factor (Table 1). Nonetheless, these data represent mostly the shale reservoir in the wet gas (condensate) and oil window, and are therefore not representative. Some data from the southwestern part of the Baltic Basin, i.e. from the dry gas window, indicate higher gas saturation, in the range of $2-3.5 \mathrm{~m}^{3} /$ ton in the case of the Wytowno S-1 borehole, and $1-11 \mathrm{~m}^{3} /$ ton in the case of the Lębork S-1 borehole (BNK, 2011).

In a case of the shale reservoirs analysed here, the content of brittle minerals is moderate to low, often ranging between 40 and $50 \%$, while the clay mineral content is relatively high, being roughly $30-50 \%$ (Fig. 22). Such a mineralogical composition might be regarded as a challenge for shale reservoir hydraulic stimulation. Nonetheless, some of the USA shale formations producing gas and oil have a comparable mineralogical composition (Fig. 22). In the Baltic Basin, a high clay content is typical of the upper Silurian shale, that has no shale oil/gas potential. The lower Silurian and Upper Ordovician shale is generally characterized by a higher content of brittle minerals (Fig. 22). In the Lublin Basin, the shale formations have higher clay contents, and in some cases also higher carbonate contents than have their equivalents in the Baltic Basin (Fig. 22). The brittleness of the lower Paleozoic shale in the Baltic-Lublin-Podlasie Basin was also defined using Poisson's ratio and Young's modulus (Kaczmarek et al., 2015; Jarzyna et al., 2017; Bała, 2017; Słota-Valim et al., 2017). Exemplary data, shown in Figure 23 , indicate a broad spectrum of shale geomechanical characteristics, although a development intermediate between brittle and ductile dominates.

TECTONIC DEFORMATION AND RESERVOIR PRESSURE REGIME

A dense grid of 2D and 3D seismic data (Fig. 3), and the deep boreholes within the Baltic-Podlasie-Lublin Basin (Fig. 2), allow constraint of the degree of tectonic deformation within the basin with high confidence. The Baltic Basin is characterized by a low degree of tectonic deformation and a near-absence of tectonic dips or folds of the sedimentary strata (Poprawa, 2010a). The pattern of faults within the basin is sparse (Poprawa, 2019), and faults are commonly of small offset, typically in the range from tens of metres to >100 m (Dom alski et al., 2004; Poprawa et al., 2006; Krzywiec, 2011, 2012; Cichostępski et al., 2019). Such a tectonic setting, which might be regarded as favourable for shale gas/oil exploration and production (Fig. 14), is shown in Figure 24A, B with examples of seismic sections from the central Baltic Basin. A similar tectonic setting characterizes the Podlasie Depression (Fig. 14). 

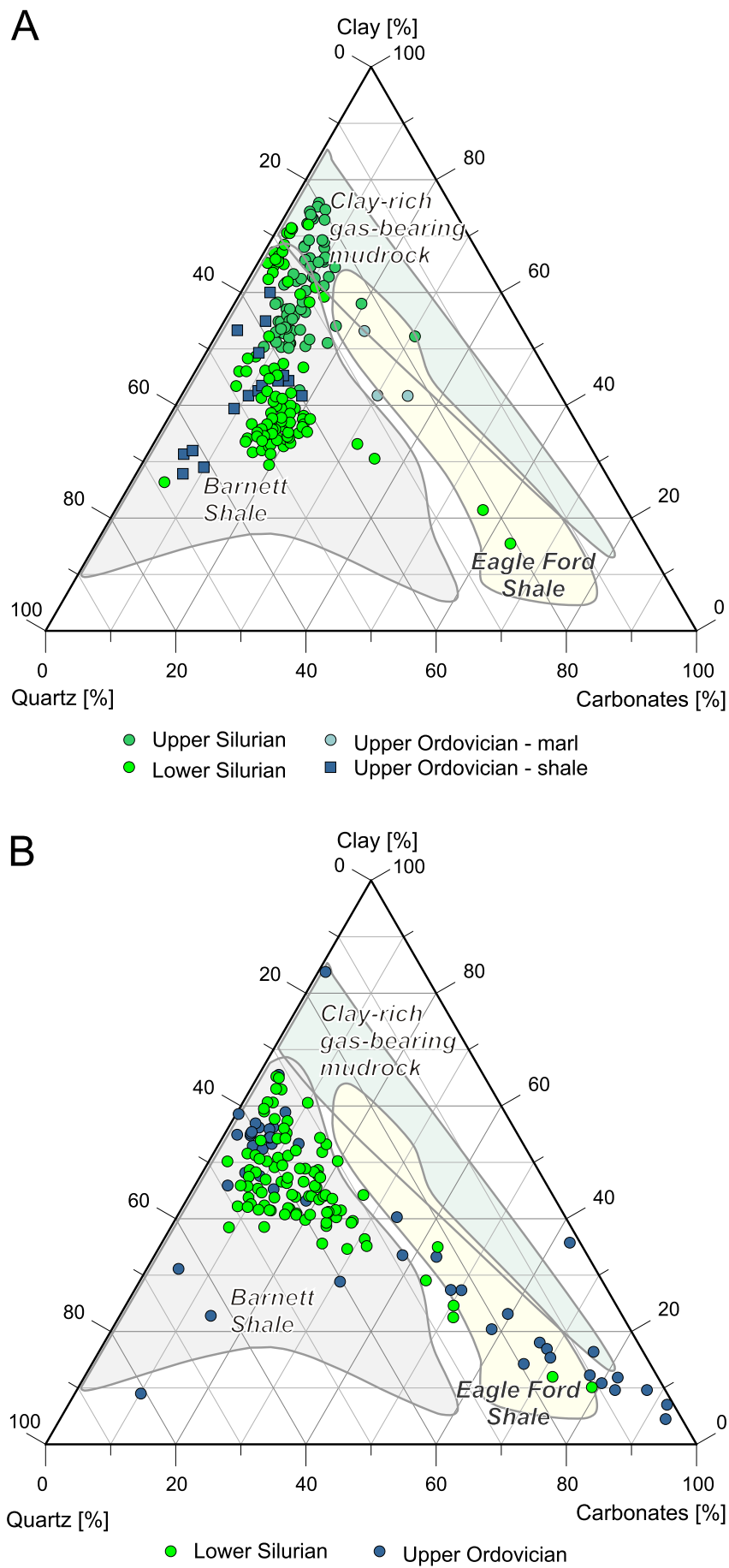

Fig. 22. Ternary plots displaying examples of bulk rock mineralogical composition of the lower Paleozoic shale reservoirs in (A) the Baltic Basin, and (B) the Lublin-Podlasie Basin

\section{A - after Jarzyna et al. (2017), supplemented B - after Zacharski (2015), supplemented}

However, in the Lublin region, the degree of tectonic deformation is significantly higher, and less favourable from the shale gas/oil point of view (Fig. 14; Poprawa, 2010a). This is expressed by a dense network of faults, and by significant compartmentalisation of the basin into individual small tectonic blocks (e.g., elichowski and Porzycki, 1983; Poprawa, 2019). However, within this structurally complex area there are individ- ual blocks with tectonically simple internal structure, as shown on the seismic section in Figure 24C.

The Biłgoraj-Narol Zone is an example of the region where a high degree of tectonic deformation is a major concern for shale gas/oil exploration and production (Fig. 14). The complex pattern of folds related to Variscan thrusting, documented with the seismic data of Krzywiec et al. (2017), results in a tectonic environment very difficult for shale gas/oil drilling and reservoir stimulation. Moreover, thrusting and folding, as well as associated uplift and denudation, impose high risks of destruction of previously generated hydrocarbons, or at least destruction of reservoir pressure.

New exploration boreholes, drilled so far in the lower Paleozoic Baltic-Podlasie-Lublin Basin, gave no indications of shale reservoir overpressure. In most of the boreholes, reservoir pressure was recorded as close to, or slightly higher than hydrostatic pressure (Fig. 14). A lack of considerable reservoir overpressure might significantly limit rates of hydrocarbon flow from exploration or production boreholes, and therefore impacts the commercial potential of the Lower Paleozoic shale play in the study area. An exception is the dry gas window in the southwestern part of the Baltic Basin, where in the Gapowo B-1 and Lębork S-1 boreholes an elevated pressure gradient was observed, of 1.34 (0.6 psi/ft) and 1.16 (0.52 psi/ft), respectively (BNK, 2014).

A lack of overpressure within a shale reservoir often results from significant tectonic uplift and denudation. However, this is presumably not the case in the Baltic-Podlasie-Lublin Basin, for which there is no evidence suggesting that Variscan uplift and erosion exceeded $3000 \mathrm{~m}$. Alternatively, an apparent lack of overpressure may be related to early hydrocarbon generation, which could have taken place during Variscan burial (Botor et al., 2002; Kosakowski et al., 2010), and locally could have been reactivated in late Mesozoic time (Poprawa and Grotek, 2005). Nonetheless, with few exploration boreholes located so far in sweet spots, the shale reservoir pressure regime might be regarded as poorly constrained.

\section{WELL TEST RESULTS AND CONSTRAINTS ON COMMERCIAL OIL/GAS PRODUCTION}

The most representative and valuable measure of exploration potential of a shale reservoir are the results of production tests in statistically representative amounts. In the lower $\mathrm{Pa}-$ leozoic Baltic-Podlasie-Lublin Basin, hydraulic fracturing and/or micro-fracturing (DFIT) tests of the shale reservoir were applied to altogether 29 exploration boreholes (Fig. 6). The boreholes tested were distributed between individual zones of the basin in the following way: 20 boreholes in the Baltic Basin, one borehole in the Płock-Warsaw Trough, two boreholes in the Podlasie Depression, five boreholes in the Lublin region, and one borehole in the Biłgoraj-Narol Zone. However, some of the well tests were not designed to give representative hydrocarbon flow rates, and were rather a low-cost preparation for eventual proper testing in a subsequent lateral borehole. This is true for hydraulic fracturing and production tests in vertical boreholes (16 boreholes in the area studied), and to an even higher degree for vertical boreholes with tests limited to DFIT (3 boreholes in the area studied). On the other hand, the most representative well tests were in multi-fractured lateral intervals, performed in the area studied in 10 boreholes, roughly half of which, however, were junked (Fig. 7).

Examples of results of the well tests are shown in Figure 25, which illustrates initial production (IP) rate per borehole and per 


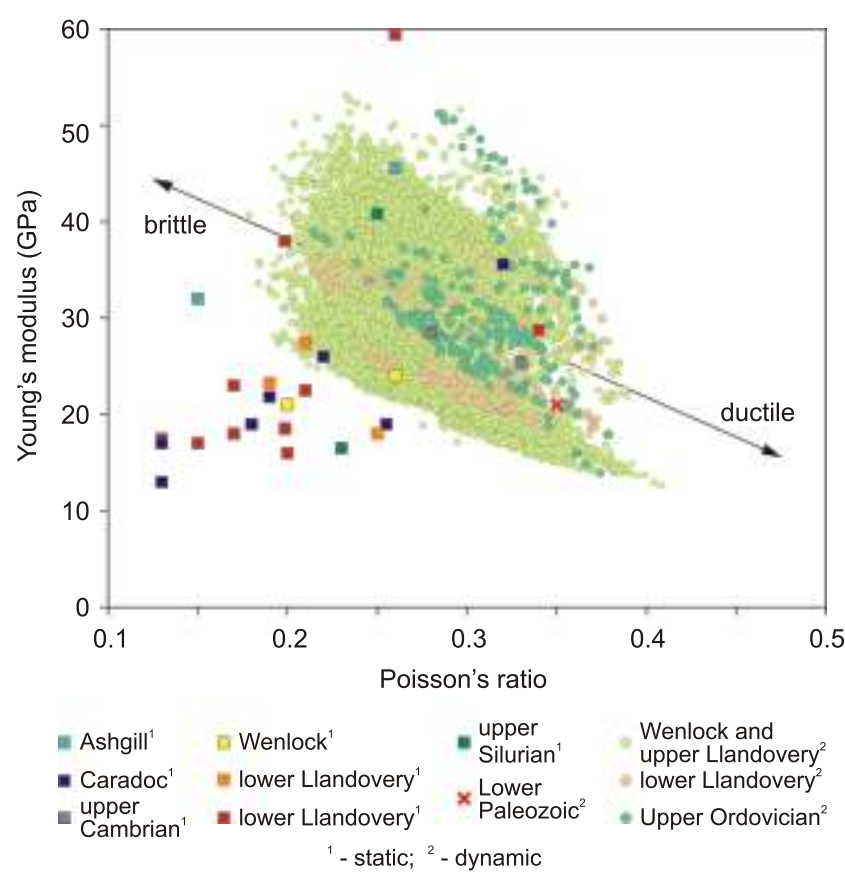

Fig. 23. Examples of data characterizing brittleness of lower Paleozoic shale in the Baltic-Lublin-Podlasie Basin; poisson's ratio versus Young's modulus

After Kaczmarek et al. (2015), Jarzyna et al. (2017), Bała (2017), Słota-Valim et al. (2017), supplemented and modified

stage, as well as the amount of stages performed in a given borehole. In most cases the test flow was supported by nitrogen lift. For the majority of these tests the landing zone was the Sasino Formation, and a few tests were performed also for the Piaśnica Formation and the Jantar Formation. The results of production tests in lateral boreholes which experienced mechanical difficulties are not representative (e.g., Warblino LE-1H, Lubocino 2H, Gapowo B-1). In the case of the Gapowo B-1 borehole, only 8 out of total of 20 stages were effectively stimulated (BNK, 2014). Even so, this borehole produced dry gas during the test at a rate of 12.6 thousand $\mathrm{m}^{3}$ per day (Fig. $25 \mathrm{~A}$ ). The best gas IP's obtained from the multifractured well tests were in the range of 11.2 thousand $\mathrm{m}^{3} /$ day (Lublewo LEP-1ST1H) and 15.6 thousand $\mathrm{m}^{3} /$ day (Łebień LE-2H), with 25 and 13 stages, respectively (Fig. 25A; NCPL, 2013; Lehr and Keeley, 2016; Poprawa et al., 2018b). In the case of the Lublewo LEP-1ST1H, during the test, in addition to gas, light oil was also produced at an amount of $157 \mathrm{bbl} /$ day ( 21.4 ton/day) (BNK, 2014), which is the equivalent of 23.5 thousand $\mathrm{m}^{3}$ of gas per day (Fig. 25A). Nonetheless, the flow rates were in general low, considerably lower than IP which could be regarded as an indicator of commercially viable production (Fig. 25).

However, the flow rates per one successive stage of hydraulic fracturing might be regarded as a better measure of the test results, since the boreholes analysed differ in stage number, and in some boreholes part of the stages experienced mechanical difficulties, and their results are barely representative. With this approach, the best recorded IP per stage are at the level of 1.1-1.6 thousand $\mathrm{m}^{3} /$ day, which might be regarded as roughly half or one-third of IP, indicating commercially viable production (Fig. 25B). An unanticipated outcome of such a comparison is that the average flow rates from an individual successful stage are similar for vertical and lateral boreholes, whilst for technological reasons one should expect significantly better IP in the second case. This indicates an up-scale potential of future hydraulic fracturing tests, which, if having a design being better adjusted to local reservoir specifics, might possibly give better hydrocarbon flows. Taking this into account, and considering the results of the well tests performed, in the two cases where the operators conducted modelling of an expected IP for a properly designed and completed well test (marked on Figure $25 \mathrm{~A}$ in grey) they concluded that commercially viable production in this region is a realistic goal.

The tests performed in the Baltic-Podlasie-Lublin Basin mostly in 2011-2014 (Fig. 6), are not of the recent technological state-of-the-art. During the time period following the decline of exploration activity in Poland, the petroleum industry in the USA experienced significant technological progress, clearly expressed by an increase of average IP in all classic shale oil and shale gas basins. Since 2012 to 2018 initial shale oil production (average of the first month) increased at least 2 to 3 times (Fig. 26A). The good example of this is the Utica shale gas play, where average IP increased from $35,000 \mathrm{~m}^{3} /$ day in 2012 , being at that time roughly twice the IP of the wells tested in Poland, to $370,000 \mathrm{~m}^{3} /$ day in 2018 (Fig. 26B). During the same time period, an average IP at the Marcellus shale gas play increased from 95,000 to $340,000 \mathrm{~m}^{3} /$ day, while at the Havnesville shale gas play it increased from 170,000 to $385,000 \mathrm{~m}^{3} /$ day (Fig. 26B).

The increase in initial production, and associated increase in estimated ultimate recovery, led to considerably higher financial incomes from shale gas/oil production. Moreover, in the USA during the last five years yet another key constraint for commercial viability of shale oil/gas fields exploitation, i.e. its average production cost, has changed. Prior to late 2014, i.e. during a period of oil prices as high as $100 \mathrm{USD} / \mathrm{bbl}$ at average, the break-even price for shale oil production was at a level of 70-80 USD/bbl (Fig. 26C). This required a high initial production and estimated ultimate recovery of an individual borehole, to retain the economics of shale oil production. Taking this into account, the collapse of oil prices in late 2014 and early 2015 , temporalily to a level as low as 25-30 USD/bbl, was expected to preclude economic production from shale basins. Nonetheless, since 2015, in the USA a significant reduction in oil/gas exploitation costs was observed, related mainly to a reduction in drilling and completion expenses. This process was driven by technological progress and cost optimisation. Due to this, the break-even price for shale oil production in USA dropped to 35-40 USD/bbl on average, i.e. roughly by half (Fig. 26C).

A significant increase in average borehole productivity and a decrease in break-even price has entirely changed the economic environment of shale oil/gas industry. This is currently referred to as a third phase of the "shale revolution", while the first and the second were the large-scale developments of shale gas and shale oil projects, since 2007 and 2009, respectively. Much higher incomes, owed to both higher production per borehole and the gradual oil price rise since 2016 to roughly 60 USD/bbl on average, being at the same time charged with much lower production costs, improved considerably the economic profit at each shale basin. Due to this, many projects, previously regarded as uneconomic, have recently been reevaluated. This has also affected the lower Paleozoic Baltic-Podlasie-Lublin Basin, where shale gas/oil exploration resulted in geological success, meaning that the presence of an effective unconventional petroleum system was demonstrated, although commercial success was not achieved.

Re-evaluation of the commercial viability of shale gas/oil production in Baltic-Podlasie-Lublin Basin requires in particular an analysis of drilling and completion costs. These costs were 

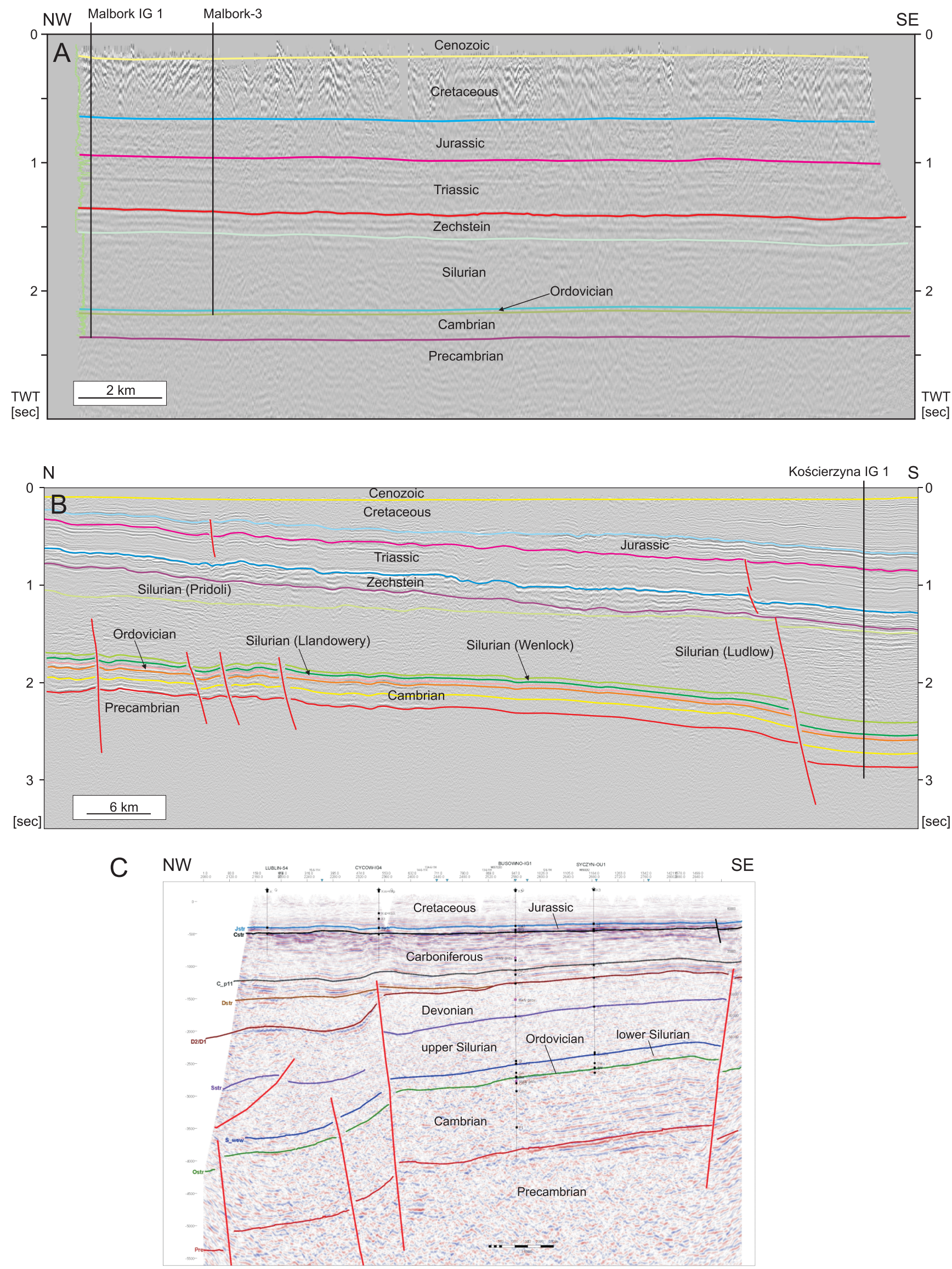

Fig. 24. Examples of seismic sections illustrating tectonic style and degree of deformation of the area analysed

Central part of the Baltic Basin: A - WO060189 (after Krzywiec, 2012), and B - 13-9-03K (after Krzywiec, 2011); southern part of the Lublin region: C - (after Zacharski, 2015); see Figure 2 for location of the sections 

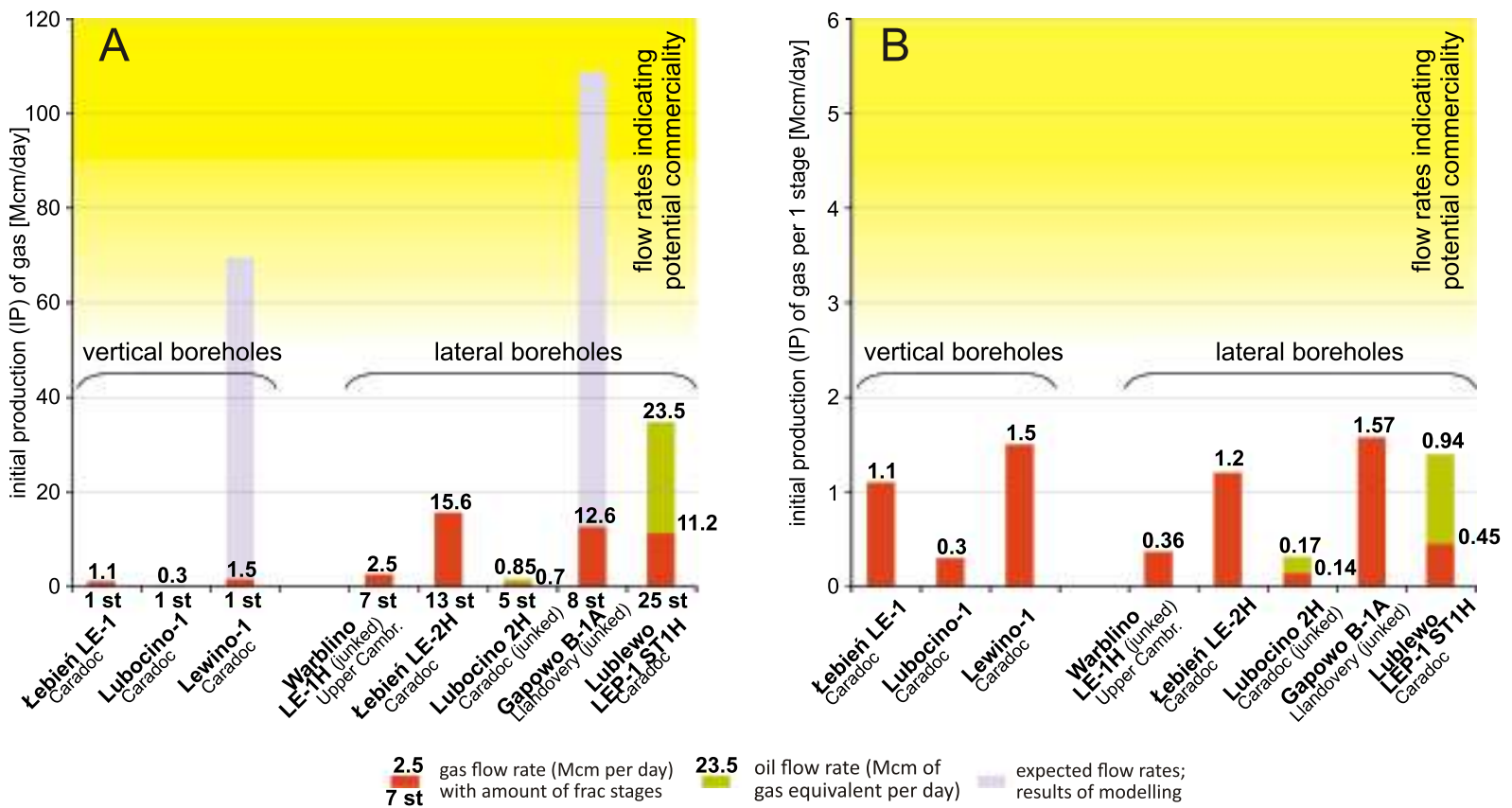

Fig. 25. Results of shale has/oil exploration well tests performed in the Baltic Basin for the lower Paleozoic unconventional reservoir

After Poprawa et al. (2018b), modified. Supplemented with data from NCPL (2013), BNK (2014), and Lehr and Keeley, (2016). A - initial production per borehole; B - initial production per stage. The initial production rate indicating commercially viable production is coloured yellow. Flow rates expected to be achieved from properly completed boreholes which avoided mechanical problems, constrained by modelling based on vertical or junked borehole data, are marked in grey. Note that in most cases the test flow was supported with nitrogen lift. st - stage

considerably higher than on average in USA shale basins at that time (Fig. 27). The high cost of exploration boreholes drilled in Poland was related mainly to a lack of a proper scale of drilling activity, which is a condition for development of a competitive service environment, and consequent cost optimisation. Drilling and completion costs vary between the basins, and also vary laterally within each basin, since they depend considerably on drilling depth. The empirical relation between the average depth of a shale gas production borehole and its average cost in the USA for 2011 is shown in Figure 27. The range of drilling and completion prices in USA might be regarded as a reference point for potential reduction of shale gas/oil exploration and production costs in Poland.

In each exploration prospect, drilling and completion costs and borehole productivity are strongly interrelated in economic analysis. To retain commercial exploitation, high production costs must be compensated by a high enough average borehole productivity, or its converse, a low average borehole productivity might be acceptable if the drilling and completion costs are low enough. In the Baltic-Podlasie-Lublin Basin, the drilling and completion costs increase laterally from the north-east to the south-west due to an increase in burial depth (Fig. 19). The last decade's experience in this basin for borehole cost should not be regarded as representative. However, it is difficult to constrain any possible reduction of drilling and completion expenses for the case of reactivation of exploration, or even more so for the case of production. Nonetheless, it is possible to determine, for a given production borehole cost, the minimum borehole productivity allowing for commercial exploitation.
For the Baltic-Podlasie-Lublin Basin, the relation between the average shale gas/oil borehole cost and the minimum estimated ultimate recovery to obtain break-even point, is shown in Figure 28 with two alternative scenarios of future long-term gas prices, i.e. 200 and $250 \mathrm{USD} / 1000 \mathrm{~m}^{3}$. These analyses are based on an assumption that on average $70 \%$ of production costs are related to drilling and completion. The remaining 30\% of production costs include government take, consisting of a hydrocarbon production fee of $6.5 \mathrm{USD} / 1000 \mathrm{~m}^{3}$, a usufruct agreement fee at a flat rate of roughly 1100 USD per borehole, and a corporate income tax of $19 \%$. Moreover, it includes also an average bank discount rate of $15 \%$, as well as gathering and transportation infrastructure costs, and operating expenditures. The analysis incorporates also the costs of negative boreholes, assumed to be $5 \%$ of all boreholes drilled. Similar assumptions are made for the relation between the average shale oil borehole cost and the minimum estimated ultimate recovery to obtain break-even point, except that the hydrocarbon production fee in this case is 14.5 USD per ton of oil, and future long-term oil prices are defined in two alternative scenarios as 50 and 60 USD/bbl (Fig. 29).

In the case of shale gas exploitation in the lower Paleozoic Baltic-Podlasie-Lublin Basin (Fig. 27), production boreholes were drilled with average total cost within the range of roughly 10 to 20 million USD. With such a borehole cost, a minimum estimated ultimate recovery to achieve break-even point with a gas price of $250 \mathrm{USD} / 1000 \mathrm{~m}^{3}$, is roughly 70 to 140 million $\mathrm{m}^{3}$ of gas (Fig. 28). With lower gas prices, of $200 \mathrm{USD} / 1000 \mathrm{~m}^{3}$, and the same borehole costs, a minimum estimated ultimate recov- 
A

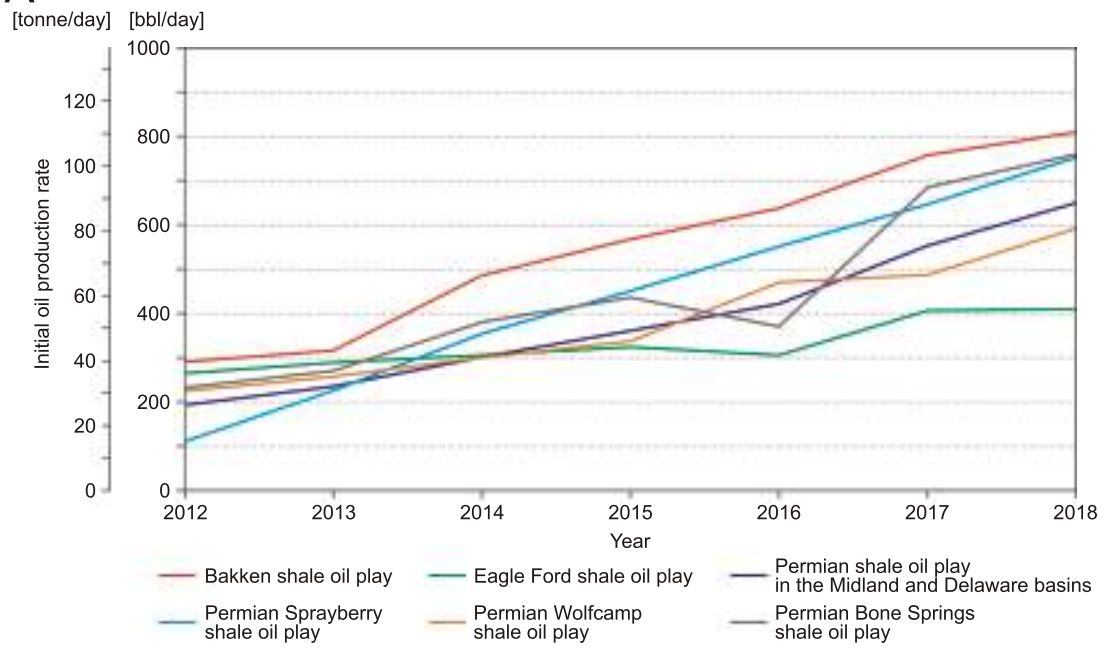

B

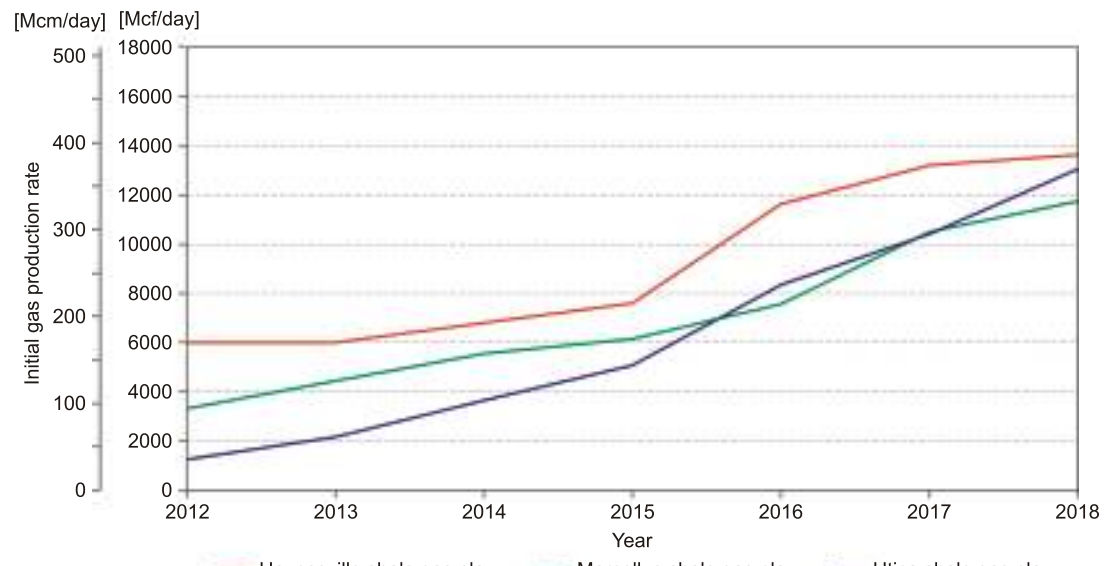

C

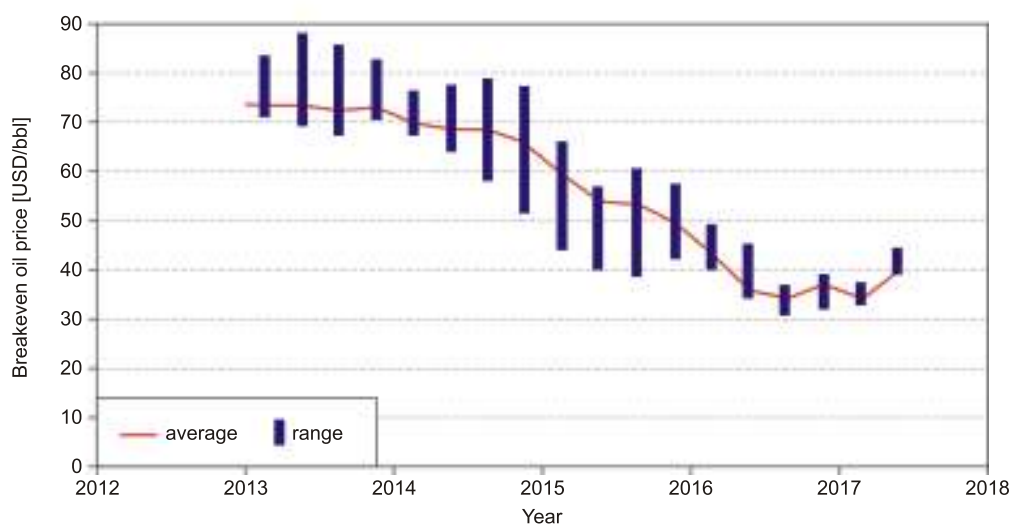

Fig. 26. Recent increase in productivity of an average borehole at shale oil and gas fields in USA, as well as decrease of average shale oil/gas production costs

Initial production rates (average of the first month) of $(\mathbf{A})$ average shale oil borehole, (B) average shale gas borehole. Data after Enverus/Drillinginfo (www.enverus.com); bbl - barrels, $\mathrm{Mcm}$ - thousand cubic metres. Mcf - thousand cubic feet. C - US shale average breakeven oil price. Data after Energy in Depth (www.energyindepth.org)

ery required for commercial production is higher, equal roughly to 90 to 170 million $\mathrm{m}^{3}$, respectively. However, for the reasons discussed above, these borehole costs should not be regarded as representative. An alternative reference point might be the
USA shale gas borehole cost, drilled to a depth similar to those in the Baltic-Podlasie-Lublin Basin, which as for 2011 was roughly 4 to 8 million USD (Fig. 28). With such drilling costs, a minimum estimated ultimate recovery to achieve break-even 


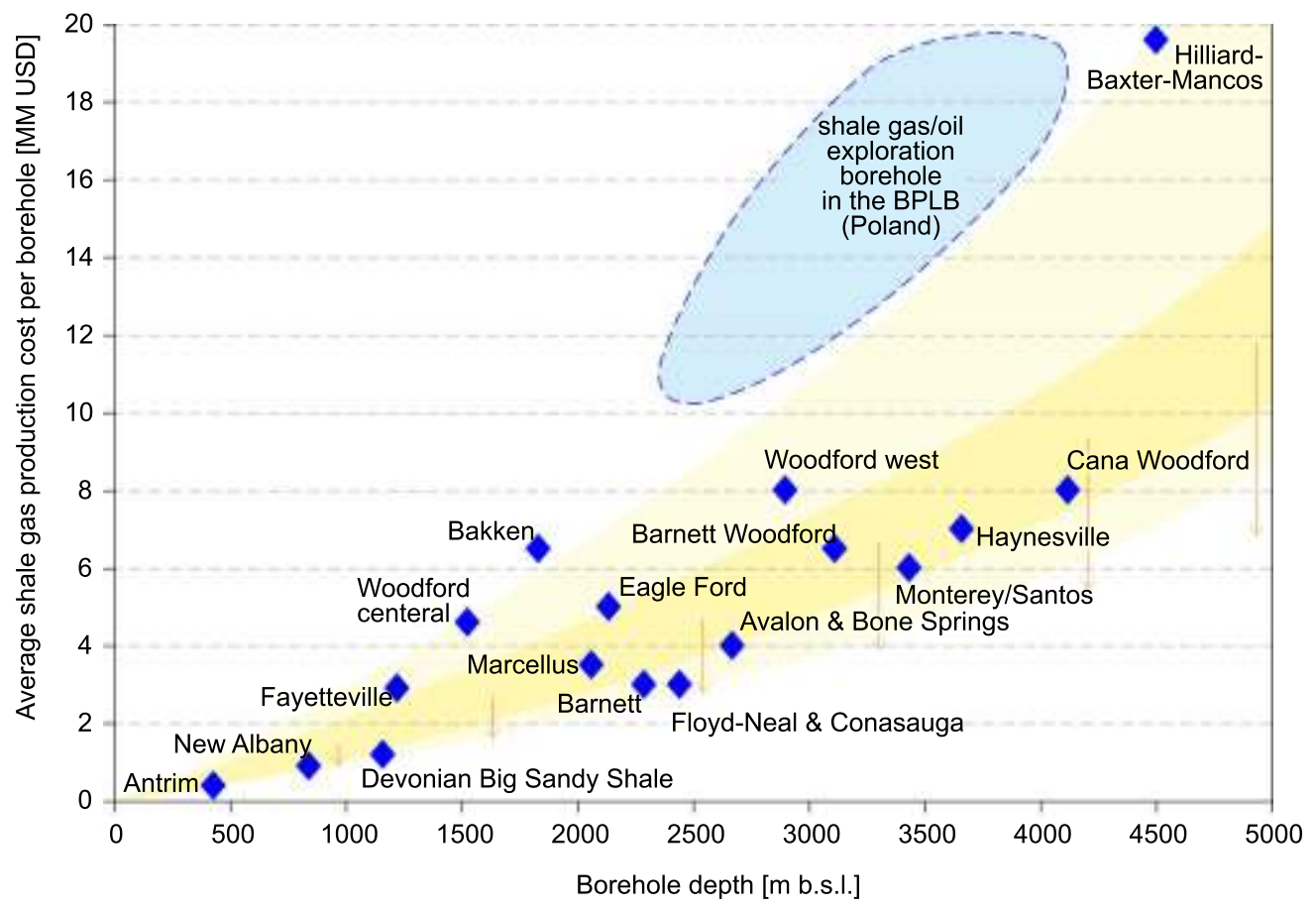

- average values representative for given US shale basin

scale of drilling and

relation between gas production cost per borehole versus

completion cost

relation between gas production cost per borehole versus
burial depth, representative for key analysed shale gas fields in US

reduction since 2011

burial depth, representative for key analysed shale gas fields

burial depth, representative for most of the analysed shale gas fields in US

Fig. 27. Average true vertical depth of lateral production borehole versus average borehole cost, for the USA shale gas and shale oil basins (based on data from EIA, 2011), compared to the depth and cost range of lateral multi-fractured exploration boreholes drilled in the Baltic-Podlasie-Lublin Basin (Poland)

Note that data are representative for 2011

point is roughly 30 to 40 million $\mathrm{m}^{3}$, with a gas price of $250 \mathrm{USD} / 1000 \mathrm{~m}^{3}$. Assuming alternative gas prices of $200 \mathrm{USD} / 1000 \mathrm{~m}^{3}$ and the same borehole costs, a minimum estimated ultimate recovery required for commercial production is $50-70$ million $\mathrm{m}^{3}$. These two alternative scenarios of the borehole costs might be regarded as end members. In the case of gas production from the lower Paleozoic shale in the Baltic-Podlasie-Lublin Basin, a representative average borehole cost would fall into this range, being presumably closer to the USA reference borehole cost. Taking into account these constraints, it might be assumed that an estimated ultimate recovery of a shale gas borehole in the Baltic-Podlasie-Lublin Basin exceeding a range of $60-90$ million $\mathrm{m}^{3}$ of gas, would most probably allow for commercial production.

The cost of an average shale oil borehole in the Baltic-Podlasie-Lublin Basin may be regarded as slightly lower than in the case of shale gas, since shale oil accumulations occur at lower burial depths (Figs. 19 and 21). Historically, such exploration borehole costs in this basin were in a broad range of 8 to 18 million USD per borehole. With this constraint, and assuming a future oil price of 60 USD per barrel, the minimum estimated ultimate recovery to achieve break-even point might be estimated at 30 to 70 thousand tons of oil per borehole (Fig. 29). With an alternative assumption of a future oil price of
$50 \mathrm{USD} / \mathrm{bbl}$, the minimum estimated ultimate recovery allowing commercial production might be estimated at 40 to 90 thousand tons of oil. Similarly as in the case of shale gas, the shale oil boreholes in USA basins are drilled considerably more cheaply than in Poland, in most of the basins for 4 to 10 million USD (Fig. 29). Adopting this range of borehole costs, and an oil price of $60 \mathrm{USD} / \mathrm{bbl}$, the minimum estimated ultimate recovery to achieve break-even point ranges between 20 to 40 thousand tons of oil per borehole (Fig. 29). A decreased in oil price to 50 USD results in an increase of minimum estimated ultimate recovery required for commercial production to $20-50$ thousand tons of oil. Even if the latter range of borehole costs might be unrealistic to achieve in the Baltic-Podlasie-Lublin Basin due to a different economic and regulatory regime and lack of competitive service sector, a future significant reduction of costs in relation to those spent on an individual borehole during the exploration phase in 2010-2016 may be anticipated. With these constraints, an estimated ultimate recovery of shale oil borehole in the Baltic-Podlasie-Lublin Basin exceeding the range of 30-50 thousand tons of oil could presumably be regarded as of commercial level.

Moreover, the initial production rates achieved during shale gas/oil exploration in the Baltic-Podlasie-Lublin Basin should not be currently regarded as representative, due to the techno- 


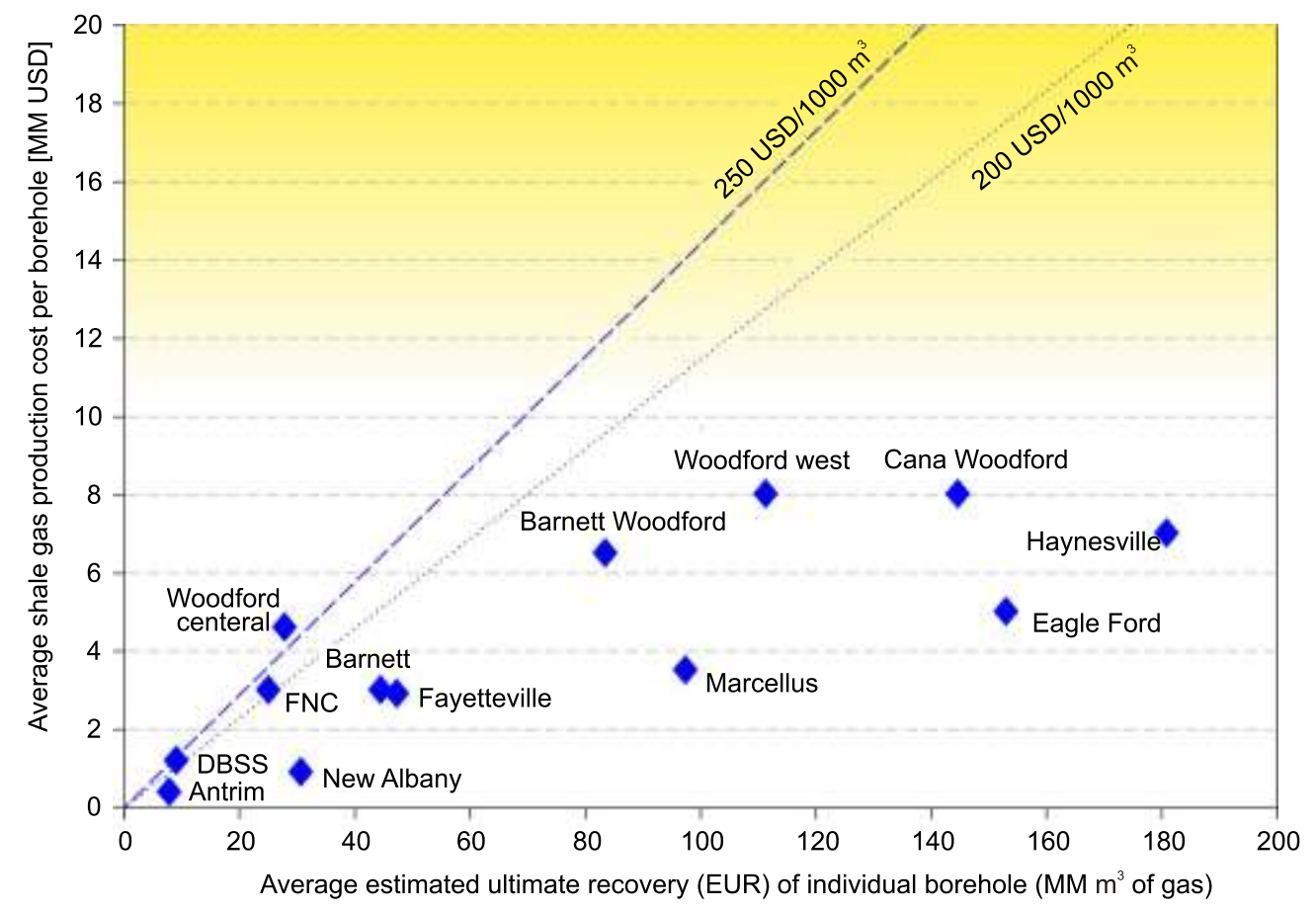

- Average values representative for given US shale basin

Range of drilling costs representative for shale gas/oil exploration boreholes in Poland

Minimum EUR for a given single borehole expences allowing for exploration cost return; a case of BPLB (Poland) with assumption of long term average market gas price 250 USD/1000 m" Minimum EUR for a given borehole expences allowing for exploration cost return;

a case of BPLB (Poland) with assumption of long term average market gas price 220 USD/1000 m

Fig. 28. Average borehole cost versus average estimated ultimate recovery (EUR) for the US shale gas basins (based on data from EIA, 2011), in relation to minimum EUR required for commercial shale gas production in the Baltic-Podlasie-Lublin Basin (Poland)

Note that data are representative for 2011; FNC - Floyd-Neal and Conasauga, DBSS - Devonian Big Sandy Shale, BPLB - Baltic-Podlasie-Lublin Basin

logical progress in stimulation of unconventional reservoirs, as experienced by the petroleum industry during the last few years. Apart from this global factor, there are also local circumstances that may improve production test results. Among these are longer horizontal borehole sections, which currently have 2000-2800 $\mathrm{m}$ as a standard.

However, the key potential for significant improvement of the well test results relates also to a different design of fracturing. So far, hydraulic fracturing has been designed to stimulate one individual shale formation, which in the central part of the Baltic Basin was mainly the Sasino Formation, less commonly the Jantar Formation or the Piaśnica Formation (Figs. 6 and 30). Attempts to frac the Sasino Formation and Jantar net pay zones simultaneously have so far been unsuccessful, because the marl of the Prabuty Formation dividing the two acts as a frac barrier. However, the thickness of this frac barrier is very small, in the central part of the Baltic Basin equal to 5-10 m (Fig. 30), while in the Płock-Warsaw Trough it is in the range of 7 to $17 \mathrm{~m}$. Considering a typical vertical extent of hydraulic fractures in shale gas/oil producing basins of roughly $50-70 \mathrm{~m}$ or more, breaking that frac barrier should not be regarded as a major technological challenge.
Moreover, in the western and northern parts of the Łeba Elevation, it might be possible to fracture the Sasino Formation and the Piaśnica Formation simultaneously (see Fig. 9A for their stratigraphic positions), since the thickness of the Słuchowo shale Formation and Kopalino limestone Formation, dividing the two net pay zones, is in the range of 15-25 $\mathrm{m}$ (Fig. 30). In the northwestern part of the Podlasie Depression and in the Biłgoraj-Narol Zone, common fracturing of the Jantar Formation and the Mingany shale might also be considered. However, in this case the two target intervals are divided by the organic-lean shale of the middle and/or upper Llandovery, typically of thickness in the range 15-30 m, which might be a challenge for their common stimulation.

Fracturing of the two net pay intervals simultaneously would allow an increase in the volume of the stimulated reservoir (Fig. 30). Such an approach, if applied successfully, has a potential to increase the effectiveness of well tests significantly, and in most prospective zones might presumably allow one to roughly double previous gas/oil test flow rates. 


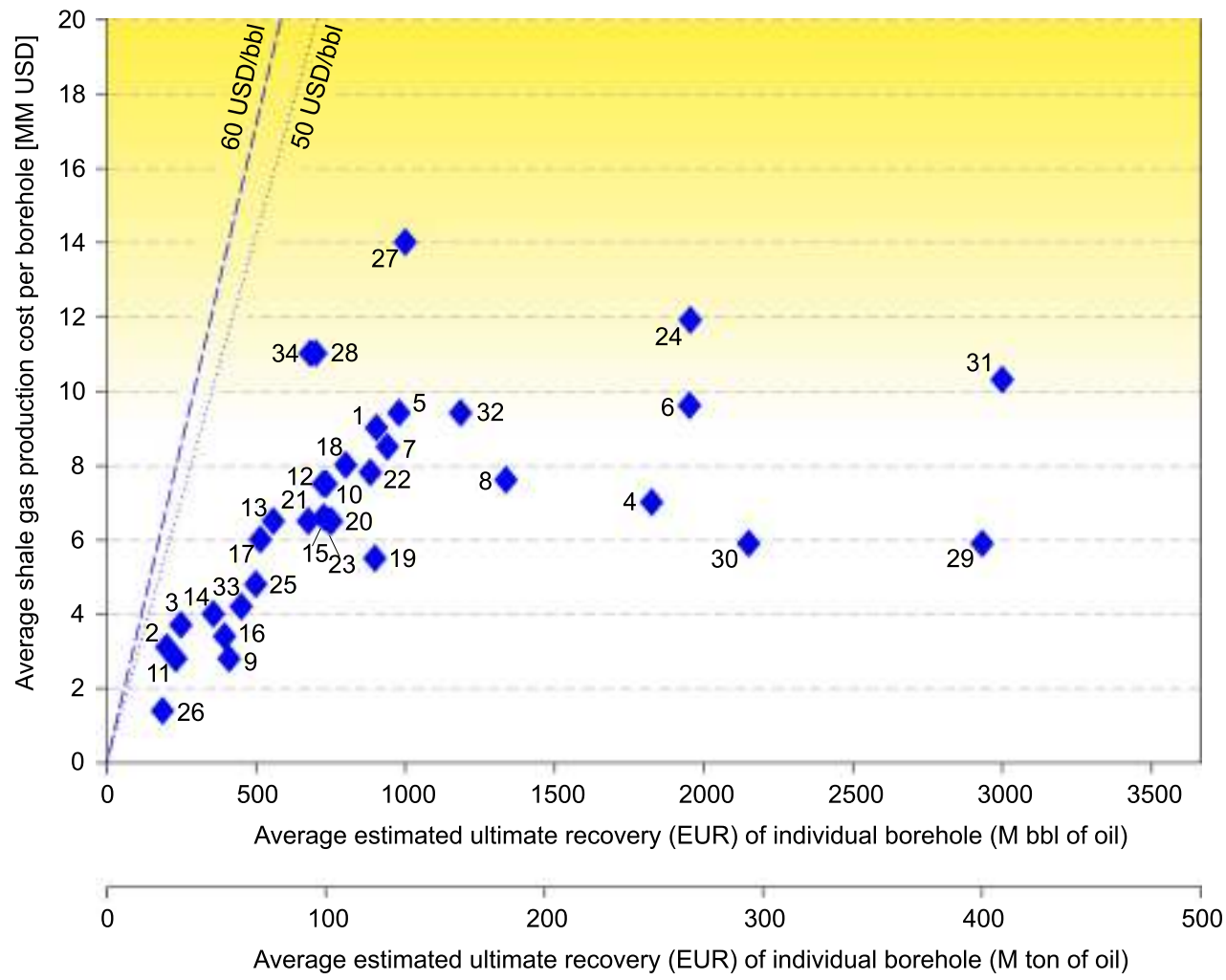

\footnotetext{
- 1 average values representative for given US shale basin; reference number explained in figure caption range of drilling costs representative for shale gas/oil exploration boreholes in Poland minimum EUR for a given single borehole expences allowing for exploration cost return; a case of BPLB (Poland) with assumption of long term average market oil price $60 \mathrm{USD} / \mathrm{bb}$ minimum EUR for a given single borehole expences allowing for exploration cost return; a case of BPLB (Poland) with assumption of long term average market oil price $50 \mathrm{USD} / \mathrm{bbl}$
}

Fig. 29. Average borehole cost versus average estimated ultimate recovery (EUR) for the US shale oil basins (based on data from Smith and Lee, 2017), in relation to minimum EUR required for commercial shale oil production in the Baltic-Podlasie-Lublin Basin (Poland)

Note that data are representative for 2017. Anadarko Basin/MidContinent; play: 1 - Springer, 2 Marmaton, 3 - Tonkawa, 4 - Cana Woodford, 5 - SCOOP Oil, 6 - SCOOP Condensate, 7 - STACK, 8 Meramec, 9 - Mississippian, 10 - Granite Wash, 11 - Cleveland. Bakken Shale; play: 12 - Bakken Core, 13 - Bakken Non Core; Denver/Julesburg Basin; play: 14 - N Wattenberg, 15 - N Wattenberg Core, 16 S Wattenberg; Eagle Ford Basin; play: 17 - Eagle Ford Oil, 18 - Eagle Ford Condensate, 19 - Eagle Ford Combo; Permian Basin; play: 20 - Midland Spraberry, 21 - N Delaware Bone Spring, 22 - S Delaware Wolfcamp, 23 - Midland Wolfcamp, 24 - Culberson LL Wolfcamp, 25 - S Midland Basin Wolfcamp; Uinta Basin; play: 26 - Greater Monument Butte, 27 - Wasatch SXL, 28 - Uteland Butte SXL; Appalachian Basin; play: 29 - SW PA Wet Gas, 30 - SW PA Super Rich, 31 - Utica Wet Gas, 32 - Utica Condensate. San Juan Basin; play: 33 - Gallup; Tuscaloosa Basin; play: 34 - Marine Shale

\section{CONCLUSIONS}

The Baltic-Podlasie-Lublin Basin is an uncommon, at a global scale, example of a lower Paleozoic basin with shale gas/oil potential. There are four individual shale formations in the basin that are regarded as a target for shale gas/oil exploration: the Piaśnica Formation (upper Cambrian and/or lower Tremadocian), the Sasino Formation (Caradoc, in some locations also uppermost Darrivillian or lowermost Ashgill), the Jantar Formation (lower Llandovery, mainly Rhuddonian), and the lower Wenlock shale (in some locations with uppermost Llandovery), here referred to as the Mingajny shale.
Deposition of the organic-rich shale in the basin was controlled mainly by tectonic processes and eustatic seal level changes, as well as by organic productivity. Oblique collision of Avalonia and Baltica resulted in diachronous development of the starved stage of the Caledonian foredeep on the western slope of the EEC (from north-west to south-east), favourable for sedimentation of condensed fine-grained sediments with elevated TOC content. Since Wenlock time, a tectonically driven increase of detritus supply from the Caledonian collision zone limited the lateral extent of organic-rich shale deposition from the west. The flexure-induced east-west asymmetry of the foredeep basin caused, in its eastern, shallower part, a replacement of shale deposition by carbonate-rich and organic-lean sedimentation. Deposition of each of the four shale formations 


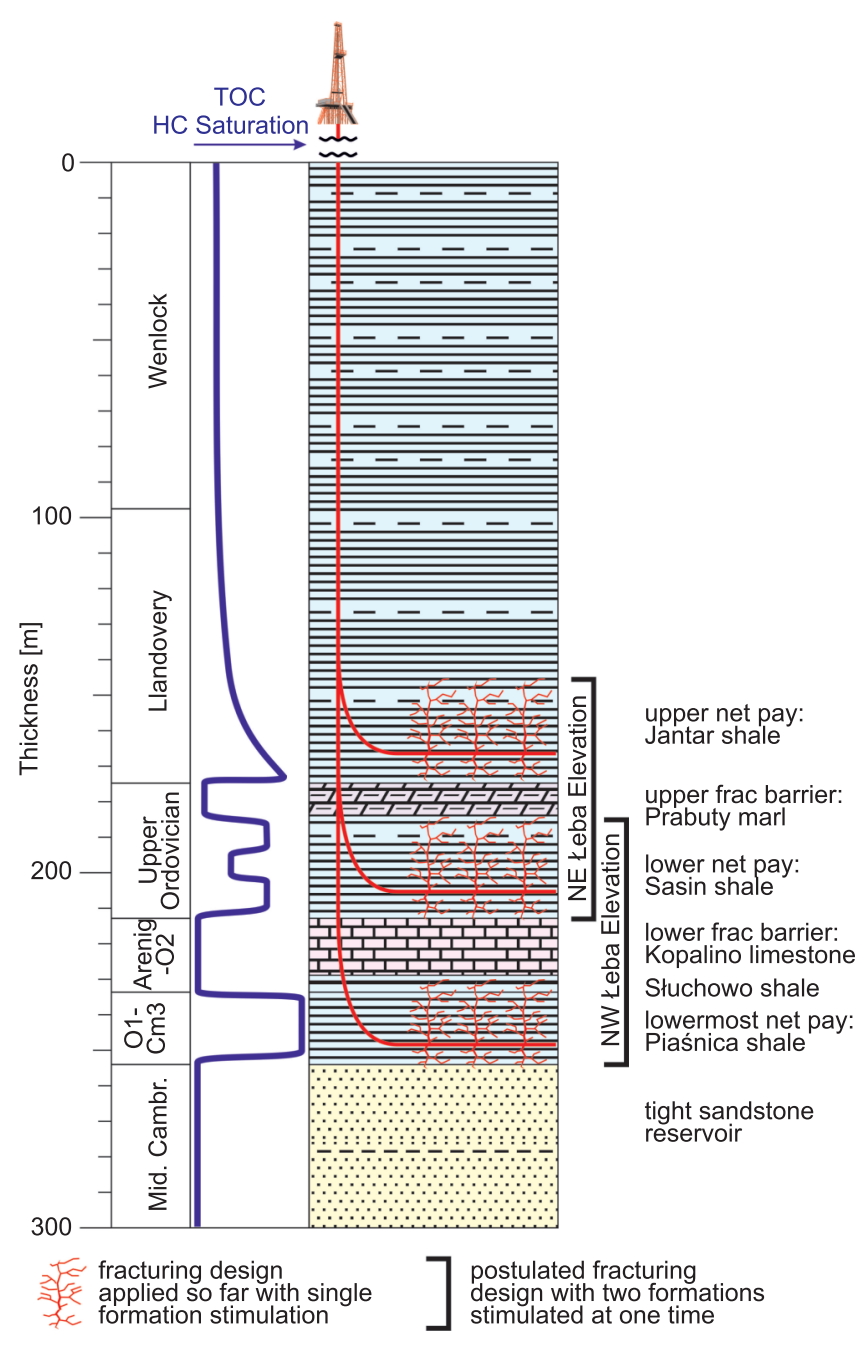

Fig. 30. Position of the net pays, being key production targets, and the frac barriers within a section of the lower Paleozoic in the central part of the Baltic Basin (Łeba Elevation, region NW of Gdańsk)

Improvement of gas/oil production rate requires common fracturing of two net pays at the same time, e.g. the Jantar and the Sasino formations on the northeastern Łeba Elevation, or the Sasino and the Piaśnica formations on the northwestern Łeba Elevation

analysed coincided with rising or high global sea level. Interruption of the Late Ordovician to Silurian deposition of organic-rich sediments during the Ashgill was caused by global seal level fall related to the Hirnantian glaciation.

The shale formations analysed are mostly condensate and oil-saturated, as indicated by their thermal maturity being commonly in the range of 0.6 to $1.3 \%$ Ro. The dry gas zone $(>1.4-1.5 \% \mathrm{Ro})$ is limited to the western and southwestern Baltic Basin, the southwestern Lublin region, and the Biłgoraj-Narol Zone. The first two of these zones, however, are characterized by relatively high recent burial depths, usually exceeding $3500-5000 \mathrm{~m}$. For this reason, economically viable shale gas production in the basin analysed is considerably more difficult than production of shale oil and shale condensate in shallower parts of the basin. Shale reservoirs saturated with light oil and condensate occur at current burial depths of 2300-3000 m and 2700-3500 m, respectively, while the wet gas zone occurs at depths of $2800-4000 \mathrm{~m}$. In the basin analysed, unconventional shale reservoirs buried to depths of $<2000 \mathrm{~m}$, typical of many USA shale basins, are located either within the early oil window, or are immature, and therefore have no shale oil/gas potential.

The lower Paleozoic unconventional shale reservoirs in the Baltic-Podlasie-Lublin Basin are saturated with hydrocarbons of good quality. Neither gas nor oil contains any components unfavourable from the economic or safety point of view. The oil is light and contains no sulphur. Gas is composed mostly of hydrocarbons, except of a few percent of $\mathrm{N}_{2}$ and $\mathrm{CO}_{2}$.

The shale formations analysed are characterized by a dominance of type II, oil-prone kerogen, and mostly moderate to low, although locally high, organic matter content. The latter, within the shale net pay zones, equals on average per borehole 2-5 wt.\% TOC. The exceptions are the Piaśnica Formation and the Mingajny shale. In the first case the average TOC is very high, $5-12 \mathrm{wt} . \%$ at average, while the latter is TOC-lean, with its content being in a range of 1.4-1.7 wt.\%. Thickness of the shale net pay in the most favourable locations reaches at most $35 \mathrm{~m}$, mainly on the Łeba Elevation, and to lesser degree in the Płock-Warsaw Trough and in the northwestern Podlasie Depression. However, in the remaining part of the study area it does not exceed $15 \mathrm{~m}$. A higher net thickness, often in the range of 30-40 m, characterizes the Mingajny shale, although only if a lower TOC content cut-off, of $1.5 \mathrm{wt} \%$, is applied.

Apart from the central part of the Baltic Basin, the PłockWarsaw Trough and the northwestern Podlasie Depression, the relatively low TOC content as regards a shale reservoir, as well as the low net pay thickness, are among the most important exploration risk factors. The other risk factors are the low to moderate shale reservoir permeability (often in the range of 150-200 mD), and apparent lack of reservoir overpressures across the major part of the study area. Reservoir overpressure (a pressure gradient of 1.34 , equivalent of $0.6 \mathrm{psi} / \mathrm{ft}$ ) was reported only for the dry gas zone in the southwestern part of the Baltic Basin. In the Biłgoraj-Narol Zone, and to a lesser degree also in the Lublin region, a high degree of tectonic deformation significantly limits shale gas/oil potential. Moreover, low reservoir gas saturation is commonly reported, although this concern is of limited significance, since it often refers to the oil and condensate window.

Total porosity of the shale net pay interval is usually in the range of $6-10 \%$, which might be considered as moderate to good. However, the clay mineral content is relatively high, at roughly $30-50 \%$. For that reason, the brittleness factor for the lower Paleozoic shale in the Baltic-Podlasie-Lublin Basin is commonly moderate. The geomechanical characteristics of the shale reservoirs studied, being intermediate between brittle and ductile, is consistent with moderate values of the Poisson's ratio and Young's modulus.

In the central and western parts of the Polish offshore Baltic Basin, the Piaśnica and Sasino formations have geological characteristics highly favourable for the development of shale oil/gas fields. Nonetheless, due to offshore economic constraints, commercially viable production of oil or gas from a shale reservoir is not possible there at the current stage of technology.

During the last decade, shale gas/oil exploration in the Baltic-Podlasie-Lublin Basin has resulted in 66 new boreholes, 29 of which were subject to hydraulic fracturing or micro-fracturing tests. However, only 10 lateral boreholes were subject to multifracturing tests so far, among which only 5 avoided significant mechanical difficulties which would affect their representativeness. Therefore, the basin might be regarded as highly underexplored from a shale gas/oil point of view. The best hydrocar- 
bon test flows obtained so far were in the range of 11.2 to 15.6 thousand $\mathrm{m}^{3} /$ day, and might be regarded as considerably lower than IP, indicating commercially viable production. However, in some cases an oil flow was obtained in addition to gas, the highest recorded rate of which was $157 \mathrm{bbl} /$ day $(21.4$ ton/day), equivalent to 23.5 thousand $\mathrm{m}^{3}$ of gas per day. Moreover, the best flow rates per each successive stage were at the level of 1.1-1.6 thousand $\mathrm{m}^{3} /$ day, which might be considered as roughly half or one-third of IP value, which would indicate commercially viable production.

The up-scale potential for further exploration in the Baltic-Podlasie-Lublin Basin is related to adjustment of fracturing design to local conditions, to application of longer lateral borehole intervals, as well as to larger vertical expansion of fractures, so they would cover two target formations. Common fracturing of two net pay intervals at one time would allow a considerable increase in the volume of stimulated reservoir, and is expected to roughly double previous test flow rates. On the northern and eastern Łeba Elevation and in the Płock-Warsaw Trough, the Sasino and the Jantar formations might be fractured together, while on the northern and western Łeba Elevation these might be the Piaśnica and Sasino formations. Significant improvement in flow rates from the lower Paleozoic shale reservoir in the Baltic-Podlasie-Lublin Basin is possible also due to general technological progress. During the last five years, this has led to increase in initial production from an individual borehole in the USA shale basins by roughly $300 \%$ on average, with coeval average borehole cost decline by approximately half.

Shale gas/oil exploration in the lower Paleozoic BalticPodlasie-Lublin Basin has demonstrated the presence of unconventional hydrocarbon accumulations, though commercially viable production was not obtained. The analysis presented here indicates that this might be achieved for shale oil boreholes with average estimated ultimate recovery exceeding $30-50$ thousand tons of oil, and in the case of shale gas with average borehole estimated ultimate recovery exceeding 60-90 million $\mathrm{m}^{3}$. The highest exploration potential is related to the northern part of the Łeba Elevation. Secondary exploration target zones might be the remaining parts of the central Baltic Basin, southwestern Lithuania, the central part of the Płock-Warsaw Trough, and the northwestern Podlasie Depression.

Acknowledgements. Constructive and helpful remarks to a previous version of the manuscript from $\mathrm{P}$. Dziadzio and J. Lazauskienè are gratefully acknowledged. This research has been financially supported by Statutory funds of the Department of Fossil Fuels no. 16.16.140.315, Faculty of Geology, Geophysics and Environmental Protection, AGH UST.

\section{REFERENCES}

Agrawal, V., Sharma, S., 2018. Improved kerogen models for determining thermal maturity and hydrocarbon potential of shale. Scientific Reports, 8: 17465. doi:10.1038/s41598-018-35560-8.

Andersson, A., Dahlman, B., Gee, D.G., Snäll, S., 1985. The Scandinavian Alum shales. Sveriges Geologiska Undersökning, 56: 1-50.

Anthonsen, K.L., Schovsbo, S., Britze, P., 2016. Overview of the current status and development of shale gas and shale oil in Europe. Report T3b of the EUOGA study (EU Unconventional Oil and Gas Assessment) commissioned by JRC- IET to GEUS.

Bakun-Czubarow, N., Białowolska, A., Fedoryshyn, Y., 2002. Neoproterozoic flood basalts of Zabolottya and Babino Beds of the volcanogenic Volhynian Series and Polesie Series dolerites in the western margin of the East European Craton. Acta Geologica Polonica, 52: 481-496.

Baltrănas, V. ed., 2004. Evolution of Earth Crust and its Resources in Lithuania (in Lithuanian with English summary). Publication of the Journal Lithosphere, Institute of Geology and Geography, Vilnius University, Vilnius.

Bała, M., 2017. Characteristics of elastic parameters determined on the basis of well logging measurements and theoretical modeling, in selected formations in boreholes in the Baltic Basin and the Baltic offshore (in Polish with English summary). Nafta-Gaz, 73: 558-570.

Bernard, S., Horsfield, B., 2014. Thermal maturation of gas shale systems. Annual Review of Earth and Planetary Sciences, 42: 635-651.

Berthelsen, A., 1992. Mobile Europe. In: A Continent Revealed the European Geotraverse (eds. D.J. Blundell, R. Freeman and S. Mueller): 11-32. Cambridge University Press, Cambridge.

Bičkauskas, G., Šeštokas, I., Kanev, S., 2016. The view on Lithuania shale potential. AAPG Europe Region Conference - Hydrocarbon Exploration in Lithuania and Baltic Region, Vilnius, Abstract Book: 2, www.aapg.org/global/Europe.

BNK, 2011. BNK Petroleum Corporate Presentation. BNK Petroleum Inc., December 2011, Camarillo.
BNK, 2014. BNK Petroleum Corporate Presentation. BNK Petroleum Inc., April 2014, Camarillo.

Bohacs, K.M., Passey, Q.R., Rudnicki, M., Esch, W.L., Lazar, O.R., 2013. The Spectrum of Fine-Grained Reservoirs from "Shale Gas" to "Shale Oil"/ Tight Liquids: Essential Attributes, Key Controls, Practical Characterization. European Association of Geoscientists and Engineers. International Petroleum Technology Conference, Mar 2013, Conference Proceedings, IPTC paper 16676. doi.org/10.3997/2214-4609-pdb.350.iptc16676

Boros, R., 2014. Mapping Shale Potential in Europe. The Newsletter of the Petroleum Exploration Society of Great Britain, June 2014: 81-83.

Botor, D., Kotarba, M., Kosakowski, P., 2002. Petroleum generation in the Carboniferous strata of the Lublin Trough (Poland): an integrated geochemical and numerical modelling approach. Organic Geochemistry, 33: 461-476.

Brangulis, A.P., Kanev, S.V., Margulis, L.S., Pomerantseva, R.A., 1993. Geology and hydrocarbon prospects of the Paleozoic in the Baltic region. In: Petroleum Geology of the NW Europe (ed. J.R. Parker): 651-656. Proceedings of the 4th Conference, London, Geological Society.

Cander, H., 2013. Finding Sweet Spots in Shale Liquids and Gas Plays: with Lessons from the Eagle Ford Shale. Search and Discovery Article \#41093, 46 pp. Www.searchanddiscovery.com/pdfz/documents/2013/41093cander/ndx cander.pdf.html

Caricchi, C., Corrado, S., Di Paolo, L., Aldega, L., Grigo, D. 2015. Thermal maturity of Silurian deposits in the Baltic Syneclise (on-shore Polish Baltic Basin): contribution to unconventional resources assessment. Italian Journal of Geosciences, 135: 383-393.

CEA, 2019. The Value of U.S. Energy Innovation and Policies Supporting the Shale Revolution. The Council of Economic Advisers. Washington, D.C.

Charpentier, R.R., Cook, T.A., 2013. Variability of Oil and Gas Wel Productivities for Continuous (Unconventional) Petroleum Ac- 
cumulations. U.S. Department of the Interior, U.S. Geological Survey, Open-File Report, 2013-1001.

Cichon-Pupienis, A., Littke, R., Froidl, F., Lazauskienè, J., 2020. Depositional history, source rock quality and thermal maturity of Upper Ordovician - lower Silurian fine-grained organic-rich sedimentary rocks in the central part of the Baltic Basin (Lithuania). Marine and Petroleum Geology, 112: 1-20.

Cichostępski, K., Kwietniak, A., Dec, J., Kasperska, M., Pietsch, K., 2019. Integrated geophysical data for sweet spot identification in Baltic Basin, Poland. Annales Societatis Geologorum Poloniae, 89: 215-231.

Cohen, K.M., Finney, S.C., Gibbard, P.L., Fan, J.-X., 2013. The ICS International Chronostratigraphic Chart. Episodes, 36 199-204.

Cocks, L.R.M., 2000. Early Palaeozoic geography of Europe. Journal of the Geological Society, 157: 1-10.

De Kock, M.O., Beukes, N.J., Adeniyi, E.O., Cole, D., Götz, A.E. Geel, C., Ossa, F.-G., 2017. Deflating the shale gas potential of South Africa's Main Karoo basin. South African Journal of Science, 113, Art. \#2016-0331.

Dembicki, H., 2017. Practical Petroleum Geochemistry for Exploration and Production. Elsevier, Amsterdam. doi.org/10.1016/C2014 0-03244-3.

Doornenbal, J.C., Stevenson, A.G. eds., 2010. Petroleum Geological Atlas of the Southern Permian Basin Area. European Association of Geoscientists and Engineers Publications b.v., Houten.

Dom alski, J., Górecki, W., Mazurek, A., Myśko, A., Strzetelski, W., Szamałek, K., 2004. The prospects for petroleum exploration in the eastern sector of Southern Baltic as revealed by sea bottom geochemical survey correlated with seismic data. Przegląd Geologiczny, 52: 792-799.

Drygant, D., Modliński, Z., Szymański, B., 2006. Lithostratigraphical correlation of the Ordovician in the Bitgoraj-Narol area with deposits of the adjacent regions of the marginal zone of the East European Craton in Poland and Ukraine (in Polish with English summary). Przegląd Geologiczny, 54: 219-227.

Dyrka, I., 2016. Petrophysical and mineralogical characterization of prospective hydrocarbon complexes estimated based on selected laboratory research results (in Polish with English summary). Przeglad Geologiczny, 64: 982-986.

Dziadzio, P.S., Porębski, S.J., Kędzior, A., Liana, B., Lis, P., Paszkowski, M., Podhalańska, T., Ząbek, G., 2017. Architektura facjalna syluru zachodniej części kratonu wschodnioeuropejskiego (in Polish). In: Opracowanie map zasięgu, biostratygrafia utworów dolnego paleozoiku oraz analiza ewolucji tektonicznej przykrawędziowej strefy platformy wschodnioeuropejskiej dla oceny rozmieszczenia niekonwencjonalnych złó węglowodorów (eds. J. Golonka and S. Bębenek): 232-277. Wydawnictwo Arka, Cieszyn.

EIA, 2011. Review of Emerging Resources: U.S. Shale Gas and Shale Oil Plays. INTEK, U.S. Energy Information Administration, U.S. Department of Energy, Washington.

EIA, 2013. Technically Recoverable Shale Oil and Shale Gas Resources: an Assessment of 137 Shale Formations in 41 Countries Outside the United States. Energy Information Administration, U.S. Department of Energy, Washington.

EIA, 2016. Trends in U.S. Oil and Natural Gas Upstream Costs. Energy Information Administration, U.S. Department of Energy, Washington.

Emetz, A., Piestrzyński, A., Zagnitko, V., 2004. Geological framework of the Volhyn copper fields with a review of the Volhyn flood basalt province (western margin of the East-European Craton). Annales Societatis Geologorum Poloniae, 74: 257-265.

Eriksson, M., 2012. Stratigraphy, facies and depositional history of the Colonus Shale Trough, Skåne, southern Sweden. Department of Geology, Lund University, Lund.

Filar, B., Kwilosz, T., Miziołek, M., Piesik-Buś, W., Zamojcin, J., 2015. The use of cluster analysis for the segmentation of the physicochemical properties of shale gas deposits. Nafta-Gaz, 71: 898-909.
Gao, W., Iqbal, J., Xu, D., Sui, H., Hu, R., 2019. Effect of brittle mineral size on hydraulic fracture propagation in shale gas reservoir. Geofluids, Article ID 9147048. doi.org/10.1155/2019/9147048

Gareckij, R.G., Zinovienko, G.V., Visnjakov, I.B., Glusko, V.V., Pomjanovskaja, G.M., Lvov, G.M., 1987. Die perikratone Baltik-Dnestr-Senkungszone. Zeitschrift für angewandte Geologie, 33: 207-213.

Gasparik, M., Bertier, P., Gensterblum, Y., Ghanizadeh, A. Krooss, B.M., Littke, R., 2013. Geological controls on the methane storage capacity in organic-rich shales. International Journal of Coal Geology, 123: 34-51.

Gautier, D.L., Pitman, J.K., Charpentier, R.R., Cook, T., Klett, T.R., Schenk, Ch.J., 2012. Potential for Technically Recoverable Unconventional Gas and Oil Resources in the Polish-Ukrainian Foredeep, Poland, 2012. U.S. Department of the Interior, U.S. Geological Survey, Fact Sheet 2012-3102.

Gale, J.F.W., Holder, J., 2010. Natural fractures in some US shales and their importance for gas production. Geological Society, London, Petroleum Geology Conference Proceedings, 7: 1131-1140.

Gale, J.F., Laubach, S.E., Olson, J.E., Eichhubl, P., Fall, A., 2014. Natural fractures in shale: a review and new observations. AAPG Bulletin, 98: 2165-2216.

Gras, R., Clayton, C.J., 1998. Non-hydrocarbon components of Carboniferous-sourced gas in the Southern Permian Basin, northwest Europe. Petroleum Geoscience, 4: 147-156.

Greiling, R.O., Jensen, S., Smith, A.G., 1999. Vendian-Cambrian subsidence of the passive margin of western Baltica - application of new stratigraphic data from the Scandinavian Caledonian margin. Norsk Geologisk Tidsskrift, 77: 133-144.

Grotek, I., 1999. Origin and thermal maturity of the organic matter in the Lower Palaeozoic rocks of the Pomeranian Caledonides and their foreland (northern Poland). Geological Quarterly, 43 (3): 297-312.

Grotek, I., 2005. Alteration of the coalification degree of the organic matter dispersed in the Carboniferous sediments along border of the East-European Craton in Poland (in Polish with English summary). Biuletyn Państwowego Instytutu Geologicznego, 413: 5-80.

Grotek, I., 2006. Thermal maturity of organic matter from the sedimentary cover deposits from Pomeranian part of the TESZ, Baltic Basin and adjacent area (in Polish with English summary). Prace Państwowego Instytutu Geologicznego, 186: 253-270.

Grotek, I., 2016. A petrologic study and thermal maturity of organic matter from the Cambrian, Ordovician and Silurian deposits in the Baltic and Podlasie-Lublin areas (in Polish with English summary). Przegląd Geologiczny, 64: 1000-1004.

Hackley, P.C., Cardott, B.J., 2016. Application of organic petrography in North American shale petroleum systems: a review. International Journal of Coal Geology, 163: 8-51.

Haq, B.U., Schutter, S.R., 2008. A chronology of Paleozoic sea-level changes. Science, 322: 64-68.

Hill, R.J., Zhang, E., Katz, B.J., Tang, Y., 2007. Modeling of gas generation from the Barnett Shale, Fort Worth Basin, Texas. AAPG Bulletin, 91: 501-521.

IEA, 2015. World Energy Outlook. International Energy Agency, Paris.

IEA, 2019. United States, 2019 Review. International Energy Agency, Paris.

Jacyna, J., Lauritzen, O., Zdanaviciute, O., Sliaupa, S., Nasedkin, V., 1997. Lithuania - Petroleum Potential and Exploration Opportunities. Lithuanian Geological Survey, Vilnius.

Jarosiński, M., Poprawa, P., Ziegler, P.A., 2009. Cenozoic dynamic evolution of the Polish Platform. Geological Quarterly, $\mathbf{5 3}$ (1): 3-26.

Jarzyna, J.A., Bała, M., Krakowska, P.I., Puskarczyk, E., Strzępowicz, A., Wawrzyniak-Guz, K., Więcław, D., Ziętek, J., 2017. Shale Gas in Poland. In: Advances in Natural Gas Emerging Technologies (eds. H. Al-Megren and R. Altamimi): 191-209. Intech.

Jarvie, D.M., 2012a. Shale resource systems for oil and gas: part 1 - shale-gas resource systems. AAPG Memoir, 97: 69-87. 
Jarvie, D.M., 2012b. Shale resource systems for oil and gas: Part 2-Shale-oil Resource Systems. AAPG Memoir, 97: 89-119.

Jarvie, D.M., 2016. Perspectives on shale resource plays, Chapter 11. In: The Role of Organic Petrology in the Exploration of Conventional and Unconventional Hydrocarbon Systems (eds. I. Suarez-Ruiz and J.G. Medonca Filho): 321-348. Bentham Science Publishers.

Jarvie, D.M., Hill, R.J., Ruble, T.E., Pollastro, R.M., 2007. Unconventional shale-gas systems: the Mississippian Barnett Shale of north-central Texas as one model for thermogenic shale-gas assessment. AAPG Bulletin, 91: 475-499.

Kaczmarek, Ł., Łukasiak, D., Maksimczuk, M., Wejrzanowski, T., 2015. The use of high-resolution X-ray computed microtomography and ultrasonic analysis for structure characterization of Paleozoic gas-bearing shales of the Baltic Basin (in Polish with English summary). Nafta-Gaz, 71: 1017-1023.

Kadūnienè, E., 2001. Organic matter in the oil source rocks. In: Petroleum Geology of Lithuania and Southeastern Baltic (eds. O. Zdanavičiūtè and K. Sakalauskas): 96-118. Institute of Geology, Vilnius.

Kaminskas, D., Michelevičius, D., Blažauskas, N., 2015. New evidence of an early Pridoli barrier reef in the southern part of the Baltic Silurian basin based on three-dimensional seismic survey, Lithuania. Estonian Journal of Earth Sciences, 64: 47-55.

Kanev, S., Margulis, L., Bojesen-Koefoed, J.A., Weil, W.A., Merta, H., Zdanavičiūtè, O., 1994. Oils and hydrocarbon source rocks of the Baltic syneclise. Oil and Gas Journal, 92: 69-73.

Karcz, P., Janas, M., 2016. Organic matter in Cambrian, Ordovician and Silurian shales of the Baltic-Podlasie-Lublin Basin in Poland (in Polish with English summary). Przegląd Geologiczny, 64: 995-999.

Karnkowski, P., 1999. Oil and gas deposits in Poland. The Geosynoptics Society, GEOS AGH, Cracow.

Karnkowski, P.H., 1997. Sedimentary basins and petroleum provinces in Poland: an overview (in Polish with English summary). Przegląd Geologiczny, 45: 989-995.

Karnkowski, P.H., Pikulski, L., Wolnowski, T., 2010. Petroleum geology of the Polish part of the Baltic region - an overview. Geological Quarterly, 54 (2): 143-158.

Kiersnowski, H., 2013. Geological environment of gas-bearing shales. In: Shale Gas as Seen by Polish Geological Survey (ed. J. Nawrocki): 26-31. Polish Geological Institute - National Research Institute, Warszawa.

Kiersnowski, H., Dyrka, I., 2013. Ordovician-Silurian shale gas resources potential in Poland: evaluation of Gas Resources Assessment Reports published to date and expected improvements for 2014 forthcoming Assessment. Przegląd Geologiczny, 61: 639-656.

Klimuszko, E., 2002. Silurian of the south-eastern Poland as a po tential source rock for Devonian oil (in Polish with English summary). Biuletyn Państwowego Instytutu Geologicznego, 402: 75-100.

Kosakowski, P., Wróbel, M., Poprawa, P., 2010. Hydrocarbon generation and expulsion modelling of the Lower Palaeozoic source rocks in the Polish part of the Baltic Basin. Geological Quarterly, 54 (2): 241-256.

Kosakowski, P., Kotarba, M.J., Piestrzyński, A., Shogenova, A., Więcław, D., 2016. Petroleum source rock evaluation of the Alum and Dictyonema Shales (Upper Cambrian-Lower Ordovician) in the Baltic Basin and Podlasie Depression (eastern Poland). International Journal of Earth Sciences, 106: 743-761.

Kotarba, M.J., Więcław, D., Kosakowski, P., Wróbel, M., Matyszkiewicz, J., Buła, Z., Krajewski, M., Koltun, Y.V., Tarkowski, J., 2011. Petroleum systems in the Palaeozoic-Mesozoic basement of the Polish and Ukrainian parts of the Carpathian Foredeep. Annales Societatis Geologorum Poloniae, 81: 487-522.

Krakowska, P.I., Jarzyna, J.A., Wawrzyniak-Guz, K., Puskarczyk, E., Zych, M., 2016. Heterogeneity analysis of the Polish shale gas formations based on results of laboratory measurements. In: International Multidisciplinary Scientific GeoConference SGEM, SGEM2017, STEF92 Technology Ltd.
Krzemińska, E., 2005. The outline of geochemical features of the Late Neoproterozoic volcanic activity in the Lublin-Podlasie basin, eastern Poland. Mineralogical Society of Poland, Special Papers, 26: 47-51.

Krzywiec, P., 2011. Interpretacja tektoniczna profili sejsmicznych w rejonie otworu wiertniczego Dar lubie IG 1 (in Polish). Profile Głębokich Otworów Wiertniczych Państwowego Instytutu Geologicznego, 128: 151-153.

Krzywiec, P., 2012. Interpretacja tektoniczna profilu sejsmicznego WO060189 (in Polish). Profile Głębokich Otworów Wiertniczych Państwowego Instytutu Geologicznego, 136: 108-109.

Krzywiec, P., Malinowski, M., Lis, P., Buffenmyer, V. Lewandowski, M., 2014. Lower Palaeozoic Basins Developed Above the East European Craton in Poland: New Insight from Regional High-Effort Seismic Reflection Data. SPE/EAGE European Unconventional Resources Conference and Exhibition, Vienna (extended abstract), Book of Abstracts, SPE-167739-MS.

Krzywiec, P., Gągała, Ł., Mazur, S., Słonka, Ł., Kufrasa, M., Malinowski, M., Pietsch, K., Golonka, J., 2017. Variscan deformation along the Teisseyre-Tornquist Zone in SE Poland: thick-skinned structural inheritance or thin-skinned thrusting? Tectonophysics, 718: 83-91.

Krzywiec, P., Poprawa, P., Mikołajczak, M., Mazur, S., Malinowski, M., 2018. Deeply concealed half-graben at the SW margin of the East European Craton (SE Poland) - evidence for Neoproterozoic rifting prior to the break-up of Rodinia. Journal of Palaeogeography, 7: 88-97.

Kuuskraa, V.A., Stevens S.H., Moodhe, K.D., 2013. Technically Recoverable Shale Oil and Shale Gas Resources: An Assessment of 137 Shale Formations in 41 Countries Outside the United States. U.S. Energy Information Administration, Washington.

Lapinskas, P., 2000. Structure and petroliferosity of the Silurian in Lithuania. Institute of Geology, Vilnius.

Lassen, A., Thybo, H., Berthelsen, A., 2001. Reflection seismic evidence for Caledonian deformed sediments above Sveconorwegian basement in the southwestern Baltic Sea. Tectonics, 20: 268-276.

Lazauskienė, J., Stephenson, R., Šliaupa, S., Van Wees, J.-D., 2002. 3-D flexural modelling of the Silurian Baltic Basin. Tectonophysics, 346: 115-135.

Lazauskienè, J., Sliaupa, S., Brazauskas, A., Musteikis, P., 2003. Sequence stratigraphy of the Baltic Silurian succession: tectonic control on the foreland infill. Geological Society Special Publications, 208: 95-115.

Le, M.-T., 2018. An assessment of the potential for the development of the shale gas industry in countries outside of North America. Heliyon, Article No e00516. doi: 10.1016/j.heliyon.2018.e00516

Lehr, J.H., Keeley, J., 2016. Alternative Energy and Shale Gas Encyclopedia. Wiley Series on Energy, New Jersey.

Levendal, T.C., Lehnert, O., Sopher, D., Erlström, M., Juhlin, C., 2019. Ordovician carbonate mud mounds of the Baltoscandian Basin in time and space - a geophysical approach. Palaeogeography, Palaeoclimatology, Palaeoecology, 535: 109345.

Leventhal, J.S., 1981. Pyrolysis gas chromatography-mass spectrometry to characterize organic matter and its relationship to uranium content of Appalachian Devonian black shales. Geochimica et Cosmochimica Acta, 45: 883-889.

Lewan, M.D., Buchardt, B., 1989. Irradiation of organic matter by uranium decay in the Alum Shale, Sweden. Geochimica et Cosmochimica Acta, 53: 1307-1322.

Luening, S., Kolonic, S., 2003. Uranium spectral gamma-ray response as a proxy for organic richness in black shales: applicability and limitations. Journal of Petroleum Geology, 26: 153-174.

Ma, L., Taylor, K.G., Dowey, P.J., Courtois, L., Gholinia, A., Lee, P.D., 2017. Multi-scale $3 D$ characterisation of porosity and organic matter in shales with variable TOC content and thermal maturity: Examples from the Lublin and Baltic Basins, Poland and Lithuania. International Journal of Coal Geology, 180: 100-112.

Mazur, S., Mikołajczak, M., Krzywiec, P., Malinowski, M., Lewandowski, M., Buffenmeyer, V., 2016. Pomeranian 
Caledonides, NW Poland - a collisional suture or thin skinned fold-and-thrust belt? Tectonophysics, 692: 29-43.

Mazur, S., Porębski, S.J., Kędzior, A., Paszkowski, M., Podhalańska, T., Poprawa, P., 2018. Refined timing and kinematics for Baltica-Avalonia convergence based on the sedimentary record of a foreland basin. Terra Nova, 30: 8-16.

McGlade, C., Speirs, J., Sorrell, S., 2013. Methods of estimating shale gas resources - comparison, evaluation and implications. Energy, 59: 116-125.

McKerrow, W.S., Cocks, L.R.M., 1986. Oceans, islands arcs and olistostromes: the use of fossils in distinguishing sutures, terranes and environments around the lapetus Ocean. Journal of the Geological Society, 143: 185-191.

Middleton, R.S., Gupta, R., Hyman, J.D., Viswanathan, H.S. 2017. The shale gas revolution: Barriers, sustainability, and emerging opportunities. Applied Energy, 199: 88-95.

Mingram, B., Hoth, P., Lüders, V., Harlov, D., 2005. The significance of fixed ammonium in Palaeozoic sediments for the generation of nitrogen-rich natural gases in the North German Basin. International Journal of Earth Sciences, 94: 1010-1022.

Modliński, Z., Szymański, B., 1997. The Ordovician lithostratigraphy of the Peribaltic Depression (NE Poland) (in Polish with English summary). Geological Quarterly, 41 (3): 273-288.

Modliński, Z., Szymański, B., 2005. The Ordovician lithostratigraphy of the Biłgoraj-Narol zone (SE Poland) (in Polish with English summary). Biuletyn Państwowego Instytutu Geologicznego, 416: 45-79.

Modliński, Z., Szymański, B., 2008. The Ordovician lithostratigraphy of the Podlasie Depresssion and the Płock-Warsaw Trough (eastern Poland) (in Polish with English summary). Biuletyn Państwowego Instytutu Geologicznego, 430: 79-112.

Modliński, Z., Szymański, B., Teller, L., 2006. The Silurian lithostratigraphy of the Polish part of the Peri-Baltic Depression ( $N$ Poland) (in Polish with English summary). Przegląd Geologiczny, 54: 787-796.

Modliński, Z. ed., Jaworowski, K., Miłaczewski, L., Pacześna, J., Podhalańska, T., Sikorska, M., Szymański, B., Waksmundzka, M.I., 2010. Paleogeological Atlas of the sub-Permian Paleozoic of the East European Craton in Poland and neighbouring areas, 1:2 000000 (in Polish with English summary). Polish Geological Institute - NRI, Warsaw.

Molenaar, N., Čyžienė, J., Šliaupa, S., 2007. Quartz cementation mechanisms and porosity variation in Baltic Cambrian sandstones. Sedimentary Geology, 195: 135-159.

NCPL, 2013. 3Legs resources resources - cracking the code to Poland's shale opportunity. Northland Capital Partners Limited, London.

Niedbalec, S., Radecki, S., 2007. Hydrocarbon accumulations in Poland. Przegląd Geologiczny, 55: 985-991.

Nielsen, A.T., Schovsbo, N.H., 2010. The Lower Cambrian of Scandinavia: depositional environment, sequence stratigraphy and palaeogeography. Earth-Science Reviews, 107: 207-310.

Pacześna, J., 2006, Evolution of late Neoproterozoic rift depocentres and facies in the Lublin-Podlasie sedimentary basin (in Polish with English summary). Prace Państwowego Instytutu Geologicznego, 186: 9-38.

Pacześna, J., 2014. Lithostratigraphy of the Ediacaran deposits in the Lublin-Podlasie sedimentary basin (eastern and south-eastern Poland) (in Polish with English summary). Biuletyn Państwowego Instytutu Geologicznego, 460: 1-24.

Pacześna, J., Poprawa, P., ywiecki, M., Grotek, I., Poniewierska, H., Wagner, M., 2005. The uppermost Ediacaran to lowermost Cambrian sediments of the Lublin-Podlasie Basin as a potential source rock formation for hydrocarbons (in Polish with English summary). Przegląd Geologiczny, 53: 499-506.

Papiernik, B., Botor, D., Golonka, J., Pietsch, K., Cichostępski, K., Porębski, S.J., 2017. Strefy formowania i zachowania niekonwencjonalnych złó węglowodorów w świetle analizy tektonicznej, sedymentologiczno-stratygraficznej i paleomią szości (in Polish). In: Opracowanie map zasięgu, biostratygrafia utworów dolnego paleozoiku oraz analiza ewolucji tektonicznej przykrawędziowej strefy platformy wschodnioeuropejskiej dla oceny rozmieszczenia niekonwencjonalnych złó węglowodorów (eds. J. Golonka and S. Bębenek): 494-502. Wydawnictwo Arka, Cieszyn.

Passey, Q.R., Bohacs, K.M., Esch, W.L., Klimentidis, R., Sinha, S., 2010. From Oil-Prone Source Rock to Gas-Producing Shale Reservoir - Geologic and Petrophysical Characterization of Unconventional Shale-Gas Reservoirs. Society of Petroleum Engineers, SPE 131350.

Paškevičius, J., 1997. The Geology of the Baltic Republics. Vilnius University, Geological Survey of Lithuania, Vilnius.

Patzek, T., Male, F., Marder, M., 2014. A simple model of gas production from hydrofractured horizontal wells in shales. AAPG Bulletin, 98: 2507-2529.

Peters, K.E., Cassa, M.R., 2002. Applied source rocks geochemistry. AAPG Memoir, 60: 93-121.

PGI, 2012. Assessment of shale gas and shale oil resources of the Lower Paleozoic Baltic-Podlasie-Lublin Basin in Poland. First report. Polish Geological Institute - National Research Institute, Warszawa.

Podhalańska, T., 2009. The Late Ordovician Gondwana glaciation - a record of environmental changes in the depositional succession of the Baltic Depression (Northern Poland) (in Polish with English summary). Prace Państwowego Instytutu Geologicznego, 193: 1-96.

Podhalańska, T., 2017. Biostratygrafia ordowiku i syluru zachodniej części kratonu wschodnioeuropejskiego (in Polish). In: Opracowanie map zasięgu, biostratygrafia utworów dolnego paleozoiku oraz analiza ewolucji tektonicznej przykrawędziowej strefy platformy wschodnioeuropejskiej dla oceny rozmieszczenia niekonwencjonalnych złó węglowodorów (eds. J. Golonka and S. Bębenek): 116-143. Wydawnictwo Arka, Cieszyn.

Podhalańska, T., Modliński, Z., 2006. Stratigraphy and facies characteristics of the Ordovician and Silurian deposits of the Koszalin-Chojnice Zone; similarities and differences to the western margin of the East European Craton and the Rügen area (in Polish with English summary). Prace Państwowego Instytutu Geologicznego, 186: 39-78.

Podhalańska, T., Waksmundzka, M.I., Becker, A., Roszkowska-Remin, J., 2016. Investigation of the prospective areas and stratigraphic horizons of the unconventional hydrocarbon resources in Poland - new results and future research directions (in Polish with English summary). Przegląd Geologiczny, 64: 953-962.

Pollastro, R.M., Jarvie, D.M., Hill, R.J., Adams, C.W., 2007. Geologic framework of the Mississippian Barnett Shale, Barnett-Paleozoic total petroleum system, Bend arch - Fort Worth Basin, Texas. AAPG Bulletin, 91: 405-436.

Pool, W., Geluk, M., Abels, J., Tiley, G., Idiz, E., Leenaarts, E., 2012. Assessment of an unusual European Shale Gas play: the Cambro-Ordovician Alum Shale, southern Sweden. Society of Petroleum Engineers, SPE-152339.

Popescu, B.M., Anastasiu, N., 2016. An overview of unconventional resources of Romania. Pending Challenges. In: Shale Gas: Ecology, Politics, Economy (ed. S. Zhiltsov): 97-139. The Handbook of Environmental Chemistry, 52. Springer, Cham.

Poprawa, P., 2006a. Neoproterozoic break-up of the supercontinent Rodiania/Pannotia recorded by development of sedimentary basins at the western slope of Baltika (in Polish with English summary). Prace Państwowego Instytutu Geologicznego, 186: 165-188.

Poprawa, P., 2006b. Development of the Caledonian collision zone along the western margin of Baltica and its relation to the foreland basin (in Polish with English summary). Prace Państwowego Instytutu Geologicznego, 186: 189-214.

Poprawa, P., 2010a. Shale gas potential of the Lower Palaeozoic complex in the Baltic Basin and Lublin-Podlasie Basin (Poland) (in Polish with English summary). Przegląd Geologiczny, 58: 226-249.

Poprawa, P., 2010b. Analysis of shale gas potential of siltstone and mudstone formations in Poland (in Polish with English summary). Biuletyn Państwowego Instytutu Geologicznego, 439: 159-172. 
Poprawa, P., 2019. Geological setting and Ediacaran-Paleozoic evolution of the western slope of the East European Craton and adjacent regions. Annales Societatis Geologorum Poloniae, $\mathbf{8 9}$ 347-380.

Poprawa, P., Pacześna, J., 2002. Late Neoproterozoic to Early Paleozoic development of a rift at the Lublin-Podlasie slope of the East European Craton - analysis of subsidence and facies record (in Polish with English summary). Przegląd Geologiczny, 50: 49-61.

Poprawa, P., Grotek, I., 2005. Revealing palaeo-heat flow and paleooverpressures in the Baltic Basin from thermal maturity modelling. Mineralogical Society of Poland, Special Papers, 26 235-238.

Poprawa, P., Kiersnowski, H., 2008. Potential for shale gas and tight gas exploration in Poland (in Polish with English summary). Biuletyn Państwowego Instytutu Geologicznego, 429: 145-152.

Poprawa, P., ywiecki, M.M., 2005. Heat transfer during develop ment of the Lublin Basin (SE Poland): maturity modelling and fluid inclusion analysis. Mineralogical Society of Poland, Special Papers, 26: 239-248.

Poprawa, P., Šliaupa, S., Stephenson, R.A., Lazauskiene, J., 1999. Late Vendian-Early Palaeozoic tectonic evolution of the Baltic basin: regional implications from subsidence analysis. Tectonophysics, 314: 219-239.

Poprawa, P., Šliaupa, S., Sidorov, V., 2006. Late Silurian to Early Devonian intra-plate compression in the foreland of Caledonian orogen (central part of the Baltic Basin) - analysis of seismic data (in Polish with English summary). Prace Państwowego Instytutu Geologicznego, 186: 215-224.

Poprawa, P., Kosakowski, P., Wróbel, M., 2010. Burial and thermal history of the western part of the Baltic Basin. Geological Quarterly, 54 (2): 131-142.

Poprawa, P., Machowski, G., Maksym, A., Zacharski, J., Papiernik, B., Stefaniuk, M., Górecki, W., Zając, J., 2016. Shale gas potential of the Ordovician-Silurian complex in the Narol Zone (SE Poland). AAPG/SEG International Conference \& Exhibition, Book of Abstracts, Cancun.

Poprawa, P., Radkovets, N., Rauball, J., 2018a. Ediacaran-Paleozoic subsidence history of the Volyn-Podillya-Moldova basin (Western and SW Ukraine, Moldova, NE Romania). Geological Quarterly, 62 (3): 459-486.

Poprawa, P., Papiernik, B., Krzywiec, P., Machowski, G. Maksym, A., 2018b. Exploration potential of the Polish petroleum provinces (in Polish with English summary). Wiadomości Naftowe i Gazownicze, 12: 4-12.

Poprawa, P., Popescu, B., Tari, G., 2018c. The Lower Paleozoic oil/gas shale plays in the Central Europe. XXI Int. Congr. of the CBGA, Salzburg, Geologica Balcanica, Abstracts, 332.

Poprawa, P., Krzemińska, E., Pacześna, J., Amstrong, R., 2020. Geochronology of the Volyn volcanic complex at the western slope of the East European Craton - relevance to the Neoproterozoic rifting and the break-up of Rodinia/Pannotia. Precambrian Research, 346: 105817.

Porębski, Sz., Podhalańska, T., 2017. Lithostratigraphy of the Ordovician and Silurian. In: Opracowanie map zasięgu, biostratygrafia utworów dolnego paleozoiku oraz analiza ewolucj tektonicznej przykrawedziowej strefy platformy wschodnioeuropejskiej dla oceny rozmieszczenia niekonwencjonalnych złó węglowodorów (eds. J. Golonka and S. Bębenek): 144-149. Wydawnictwo Arka, Cieszyn.

Porębski, Sz., Podhalańska, T., 2019. Ordovician-Silurian lithostratigraphy of the East European Craton in Poland. Annales Societatis Geologorum Poloniae, 89: 95-104

Porębski, S.J., Prugar, W., Zacharski, J., 2013. Silurian shales of the East European Platform in Poland-some exploration problems. Przeglad Geologiczny, 61: 630-638.

Porębski, S.J., Anczkiewicz, R., Paszkowski, M., Skompski, S. Keedzior, A., Mazur, S., Szczepański, J., Buniak, A., Mikołajewski, Z., 2019. Hirnantian icebergs in the subtropical shelf of Baltica: Evidence from sedimentology and detrital zircon provenance. Geology, 47: 1-5.
PPI Energy and Chemicals Team, 2013. The effects of shale gas production on natural gas prices. Cornell University ILR School. Washington, DC: Bureau of Labor Statistics. Beyond the Numbers, $2: 1-10$.

Prugar, W., 2013. Depositional environment and hydrocarbon habitat of the Lower Paleozoic deposits in the central and southern part of the Lublin Trough (in Polish with English summary). Ph.D. thesis, Library of AGH University of Sciences and Technology, Kraków.

Puskarczyk, E., 2019. Artificial neural networks as a tool for pattern recognition and electrofacies analysis in Polish Palaeozoic shale gas formations. Acta Geophysica, 67: 1991-2003.

Radkovets, N., 2015. The Silurian of southwestern margin of the East European Platform (Ukraine, Moldova and Romania): lithofacies and palaeoenvironments. Geological Quarterly, 59 (1): 105-118.

Radkovets, N.Y., Rauball, J., Jaremchuk, I., 2017. Silurian black shales of Western Ukraine: petrography and mineralogy. Estonian Journal of Earth Sciences, 66: 161-173.

Radkovets, N., Kosakowski, P., Rauball, J., Zakrzewski, A., 2018. Burial and thermal history modelling of the Ediacaran succession in Western and SW Ukraine and Moldova. Journal of Petroleum Geology, 41: 85-106.

Rasmussen, B.W., Rasmussen, J.A., Nielsen, A.T., 2017 Biostratigraphy of the Furongian (upper Cambrian) Alum Shale Formation at Degerhamn, Oland, Sweden. GFF. http://dx.doi.org/10.1080/11035897.2016.1276099.

Sachsenhofer, R.F., Koltun, Y.V., 2012. Black shales in Ukraine - a review. Marine and Petroleum Geology, 31: 125-136.

Sakalauskas, K., 2001. Key features of the geologiacal setting. Tectonics: an overview of regional structure features. In: Petroleum Geology of Lithuania and Southeastern Baltic (eds. O. Zdanavičiūtè and K. Sakalauskas): 19-45. Institute of Geology, Vilnius.

Sandrea, R., Sandrea, I., 2014. New well-productivity data provide US shale potential insights. Oil and Gas Journal, 112: 1-11.

Schovsbo, N.H., 2002. Uranium enrichment shorewards in black shales: a case study from the Scandinavian Alum Shale. GFF, 124: $107-116$.

Schovsbo, N.H., Nielsen, A.T., Klitten, K., Mathiesen, A., Rasmussen, P., 2011. Shale gas investigations in Denmark: Lower Palaeozoic shales on Bornholm. Geological Survey of Denmark and Greenland Bulletin, 23: 9-12.

Schovsbo, N.H., Anthonsen, K.L., Pedersen, C.B., Tougaard, L., 2017. Overview of shale layers characteristics in Europe relevant for assessment of unconventional resources. Delivery T6b of the EUOGA study (EU Unconventional Oil and Gas Assessment) commissioned by JRC-IET to GEUS. Appendix Volume.

Schovsbo, N.H., Nielsen, A.T., Harstad, A.O., Bruton, D.L., 2018. Stratigraphy and geochemical composition of the Cambrian Alum Shale Formation in the Porsgrunn core, Skien-Langesund district, southern Norway. Bulletin of the Geological Society of Denmark, 66: 1-20.

Semyrka, R., Jarzyna, J., Semyrka, G., Kazmierczuk, M., Pikulski, L., 2010. Reservoir parameters of lithostratigraphic successions of the lower Paleozoic strata in the Polish part of the Baltic region based on laboratory studies and well logs. Geological Quarterly, 54 (2): 227-240.

Sikorska, M., 1998. The role of diagenesis in development of pore space of the Cambrian sandstones from the Polish part of the East European Platform (in Polish with English summary). Prace Państwowego Instytutu Geologicznego, 164: 1-66.

Skręt, U., Fabiańska, M.J., 2009. Geochemical characteristics of organic matter in the Lower Palaeozoic rocks of the Peribaltic Syneclise (Poland). Geochemical Journal, 43: 343-369.

Sliaupa, S., Fokin, P., Lazauskienè, J., Stephenson, R.A., 2006. The Vendian-Early Palaeozoic sedimentary basins of the East European Craton. Geological Society Memoirs, 32: 449-462.

Sliaupa, S., Sliaupienè, R., Zalădienè, G., Vaskaboinikava, T., Bibikava, A., Evstratenko, L., Kovkhuto, A., 2016. Prospects of Lithuanian Silurian shale gas, Baltic Sedimentary Basin. Oil Shale, 33: 357-372. 
Słota-Valim, M., Sowi d ał, K., Jędrzejowska-Tyczkowska, H., 2017. Geomechanical modelling of Paleozoic Shale Gas Formation: a case study from the Baltic Basin, northern Poland. Geology, Geophysics and Environment, 43: 249-269.

Smith, J.L., Lee, T.K., 2017. The Price Elasticity of U.S. Shale Oil Reserves. U.S. Energy Information Administration, Working Paper Series, Washington.

Sone, H., Zoback, M.D., 2013a. Mechanical properties of shale-gas reservoir rocks - part 1: Static and dynamic elastic properties and anisotropy. Geophysics, 78: D381-D392.

Sone, H., Zoback, M.D., 2013b. Mechanical properties of shale-gas reservoir rocks - part 2: Ductile creep, brittle strength, and their relation to the elastic modulus. Geophysics, 78: D393-D402.

Song, W., Yao, J., Li, Y., Sun, H., Zhang, L., Yang, Y., Zhao, J., Sui, H., 2016. Apparent gas permeability in an organic-rich shale reservoir. Fuel, 181: 973-984.

Sopher, D., Erlström, M., Bell, N., Juhlin, C., 2016. The structure and stratigraphy of the sedimentary succession in the Swedish sector of the Baltic Basin: new insights from vintage 2D marine seismic data. Tectonophysics, 676: 90-111.

Sowi d ał, K., Stadtmüller, M., Lis-Śledziona, A., Kaczmarczyk, W., 2016. Comparative analysis of shale formations in selected areas of the Baltic Basin based on well data interpretation and 3D geological modelling (in Polish with English summary). Nafta-Gaz, 72: 891-900.

Spaw, J.M., Hlava, K.S., 2014. Mudstone Lithofacies Evaluation for Play Fairway Analysis: characterization of the Paleozoic Shales of Poland. AAPG Annual Convention and Exhibition, Houston, Texas, April 6-9, 2014, Search and Discovery Article \#10674.

Spirakis, C.S., 1996. The roles of organic matter in the formation of uranium deposits in sedimentary rocks. Ore Geology Reviews, 11: 53-69.

Stolarczyk, F., Stolarczyk, J., Wysocka, H., Buchelt, M., 1997. Strefy perspektywiczne dla występowania węglowodorów w kambrze lubelsko-podlaskiej części starej platformy (in Polish). Przegląd Geologiczny, 45: 171-175.

Stolarczyk, F., Stolarczyk, J., Wysocka, H., 2004. Primary areas for hydrocarbon prospecting in the Cambrian of the Polish part of the East European Platform (in Polish with English summary). Przegląd Geologiczny, 52: 403-412.

Szymański, B., 2008. The Upper Cambrian and Tremadocian lithostratigraphic and microfacies record of the Baltic Depression (northern Poland) (in Polish with English summary). Biuletyn Państwowego Instytutu Geologicznego, 430: 113-154.

Tari, G., Poprawa, P., Krzywiec, P., Popescu, B., Micu, M., Krezsek, C., Rainer, T., 2016. Pro-foreland flexural basin interpretation of the Silurian Basin of Central and Eastern Europe: a review. AAPG Regional Conference, Bucharest, Abstract Book: 153-154, http://europeevents.aapg.org/Bucharest, 2016.

Tella, T., 2011. Estimating Reserves for Unconventional Shale Resource Plays. Society of Petroleum Evaluation Engineers, Tulsa, https://spee.org/resources/past_presentations.

Tissot, B.P., Welte, D.H., 1984. Petroleum Formation and Occurrence. Second Revised and Enlarged Edition, Springer, Berlin.

Ulmishek, G.F., 1990. Geologic evolution and petroleum resources of the Baltic Basin. AAPG Memoir, 51: 603-632.

Vejbæk, O.V., Stouge, S., Poulsen, K.D., 1994. Palaeozoic tectonic and sedimentary evolution and hydrocarbon prospectivity in the Bornholm area. Danmarks Geologiske Undersrgelse, Serie A, 34: 1-23.

Wagner, R., 1994. Stratigraphy and development of the Zechstein basin in the Polish Lowlands (in Polish with English summary). Prace Państwowego Instytutu Geologicznego, 146: 1-71.

Wang, Z., Krupnick, A., 2015. A retrospective review of shale gas development in the United States: what led to the boom? Economics of Energy and Environmental Policy, 4: 5-18.

Wang, H., Ma, F., Tong, X., Liu, Z., Zhang, X., Wu, Z., Li, D., Wang, B., Xie, Y., Yang, L., 2016. Assessment of global unconven- tional oil and gas resources. Petroleum Exploration and Development, 43: 925-940.

Wawrzyniak-Guz, K., 2019. Rock physics modelling for determination of effective elastic properties of the lower Paleozoic shale formation, North Poland. Acta Geophysica, 67: 1967-1989.

Whitelaw, P., Uguna, C.N., Stevens, L.A., Meredith, W., Snape, C.E., Vane, C.H., Moss-Hayes, V., Carr, A.D., 2019. Shale gas reserve evaluation by laboratory pyrolysis and gas holding capacity consistent with field data. Nature Communications, 10 3659.

Więcław, D., Kotarba, M., Kosakowski, P., Kowalski, A., Grotek, I., 2010. Habitat and hydrocarbon potential of the Lower Palaeozoic source rocks of the Polish sector of the Baltic Sea. Geological Quarterly, 54 (2): 159-182.

Wójcicki, A., 2015. Assessment of unconventional gas resources in Poland (in Polish with English summary). Przegląd Geologiczny, 63: $1215-1219$

Wójcicki, A., Kiersnowski, H., Dyrka, I., Adamczak-Biały, T., Becker, A., Głuszyński, A., Janas, M., Kozłowska, A., Krzemiński, L., Kuberska, M., Pacześna, J., Podhalańska, T., Roman, M., Skowroński, L., Waksmundzka, M.I., 2014. Prognostyczne zasoby gazu ziemnego w wybranych zwięzłych skałach zbiornikowych Polski (in Polish). Państwowy Instytut Geologiczny - Państwowy Instytut Badawczy, Warszawa.

Yang, S., Schulz, H.-M., Schovsbo, N., Bojesen-Koefoed, J.A., 2017. Oil-source-rock correlation of the Lower Paleozoic petroleum system in the Baltic Basin (northern Europe). AAPG Bulletin, 101: 1971-1993.

Zacharski, J., 2015. Geological setting and reservoir heterogeneity of Lower Paleozoic shales in the Lublin Basin (Poland) and its impact on exploration. AAPG European Regional Conference and Exhibition, Lisbon, Book of abstracts. http://www.searchanddiscovery.com/abstracts/html/2015/90226erm/abstracts/10494187.html

Zdanavičiūtè, O., Bojesen-Koefoed, J.A., 1997. Geochemistry of Lithuanian oils and source rocks: a preliminary assessment. Journal of Petroleum Geology, 20: 381-402.

Zdanaviciute, O., Lazauskiene, J., 2007. The petroleum potential of the Silurian succession in Lithuania. Journal of Petroleum Geology, 30: 325-337.

Zdanavičiūtè, O., Lazauskienè, J., 2009. Organic matter of Early Silurian succession - the potential source of unconventional gas in the Baltic Basin (Lithuania). Baltica, 22: 89-98.

Zdanavičiūtè, O., Swadowska, E., 2002. Petrographic and pyrolysis-gas chromatography investigations of the Lower Palaeozoic organic matter of Lithuania. Geologija, 40: 15-22.

Zdanavičiūtè, O., Khubldikov, A.I., Bojesen-Koefoed, J.A., 1998. Geology and Oil Geochemistry of the Eastern Part of the Baltic Syneclise. In: Perspective of Petroleum Exploration in the Baltic Region (eds. P. Suveizdis and O. Zdanavičiūtè): 58-65. Proceedings of the International Conference. Institute of Geology, Vilnius.

Zijp, M.H.A.A., Nelskamp, S., Doornenbal, J.C., 2017. Resource estimation of shale gas and shale oil in Europe. Report T7b of the EUOGA study (EU Unconventional Oil and Gas Assessment) commissioned by European Commission Joint Research Centre to GEUS, Brussels.

Zoback, M.D., Kohli, A.H., 2019. Unconventional Reservoir Geomechanics. Shale Gas, Tight Oil, and Induced Seismicity. Cambridge University Press, Cambridge.

Zou, C., Zhu, R., Tao, S., Hou, L., Yuan, X., Song, Y., Niu, J., Dong, D., Liu, S., Jiang, L., Wang, S., Zhang, G., 2013. Unconventional Petroleum Geology. Petroleum Industry Press, Elsevier Inc., http://dx.doi.org/10.1016/B978-0-12-3971623.00001-3

elichowski, A.M., Porzycki, J., 1983. Geological and structural map without Carboniferous and younger strata (in Polish with English summary). In: Atlas of Geological Structure and Mineral Deposits in the Lublin Basin (eds. A.M. elichowski and S. Kozłowski). Wyd. Geol., Warszawa. 